\title{
DE LEGENDE VAN DE HEILIGE ZEVEN SLAPERS IN HET ATJEHSCH.
}

DOOR

H. T. DAMSTÉ.

Te Ephesus is het graf van Johannes den Evangelist. De grond - zegt men - is er in stage beroering: een teeken dat hij leeft die daar rust onder de zoden.

Te Ephesus zijn véle graven, en in den grond daar was extra beroering de laatste veertig jaar door de nasporingen die Oostenrijksche archaeologen er verrichtten naar de graven van de Heilige Zeven Slapers.

Hadden die onderzoekingen succes? Het publiek meende van wèl.

Hoort de „Nouvelliste Valaisan”, een Zwitsersch blaadje van 30 Juli 1931:

En effet, non loin du tombeau de l'Apôtre (St Jean l'Evangéliste), les archéologues autrichiens (Frantz Miltner) ont découvert un autre lieu célèbre: la Grotte des 7 Dormants.

Sous le règne de Décius, grand persécuteur de la foi nouvelle, en 240 de notre ère, 7 jeunes chrétiens d'Éphèse, condamnés à mort, se réfugièrent dans une grotte. Les gens à leur poursuite découvrirent leur refuge. Ils en murèrent l'ouverture avec des pierres afin de les faire mourir de faim. Les 7 jeunes gens, après avoir prié Dieu, se couchèrent pour dormir. Deux cents ans plus tard la grotte fut par hasard ouverte. Les 7 dormants se réveillèrent. Ils crurent n'avoir dormi qu'une nuit. L'un d'eux se rendit dans la ville, où le Christianisme régnait maintenant et l'histoire des 7 s'ébruita par lui. L'évèque, le gouverneur de la ville d'Éphèse et les notables, suivirent le jeune homme à la grotte, où l'on trouva les 6 autres. „Leurs visages étaient frais comme des roses et l'éclat d'une sainte lumière les couronnait" dit la légende. Après avoir confirmé le miracle, ils se rendormirent du sommeil éternel. Fable! ont déclaré les historiens : les 7 dormants n'ont jamais existé! Mais voilà que le dr. Miltner a découvert leur tombe! Chose curieuse, le sépulcre porte gravée la 
date de 445 après J. C., c'est à dire à peu près l'année où les 7 jeunes gens se réveillèrent. Autour de la grotte se trouvaient de nombreux tombeaux. Ils appartenaient probablement à des personnes pieuses qui recommandaient à leurs proches de les inhumer près de ce lieu dans l'espoir que le miracle se répéterait pour eux.

Iets nuchterder is Pfarrer Josef Tremmel in „Tiroler Heimatblätter" Januari 1934. In de 6de eeuw en later - zegt hij — ontmoet men de legende van „Die heiligen Siebenschläfer” in alle talen van het Oosten. Gregor von Tours liet ze door een Syriër vertalen; sinds werd ze, vooral sinds de 11de eeuw, ook in het Westen populair.

$\mathrm{Na}$ den inhoud te hebben gegeven, merkt de schrijver op:

In neuester Zeit haben österreichische Forscher die Grabkammer und die Kirche sowie einen anschliessenden altchristlichen Friedhof wieder freigelegt, so dass der Legende irgendeine geschichtliche Grundlage gewiss nicht abgesprochen werden kann.

Zien wij nu de meer wetenschappelijke berichtgeving: het in 1937 verschenen 4de deel der „Forschungen in Ephesos”, veröffentlicht vom Österreichischen Archaeologischen Institute, dan lezen wij, dat o.m. is blootgelegd: een kerk-complex - gemeend wordt, op aangevoerde redelijke gronden, uit het midden der 5de eeuw - met daaronder de catacomben van - naar men meent, omdat men geen reden ziet dat $\mathrm{niet}$ te meenen - de zeven heilige jongelingen. Maar jaartallen of inscripties die de juistheid van zulke meeningen bevestigen, zijn niet gevonden; wèl muurkrabbels van bezoekers, soms gedateerd, en dan uit de $14 \mathrm{e}$ en 15e eeuw: Armeniaansche geestelijken en lieden uit de in den handel op de Levant geinteresseerde landen, óók uit onze lage-landen-aan-de-zee; zij meenden daar te staan bij de graven der zeven ,kinderen” of ,broeders”, dat is wel zeker!

Maar tezelfder tijd en vroeger en later waren er anderen, die de rustplaats der Zeven Slapers elders dachten.

Of zij, die - als De Goeje - het Ephesus der legende vereenzelvigden met Afsus of Arabissus in Kappadocië, en zij, die - als Clermont-Ganneau — de grot in Palestina omstreeks Belgā-'Ammān hadden gezocht, naar aanleiding van de uitkomsten der Oostenrijksche archaeologen de vlag willen strijken?... De plaatsbepaling zal wel één twistvraag blijven, naast die andere over de taal - Syrisch, Grieksch of Latijn -- waarin de legende het eerst zou zijn gesteld en doorgegeven, 
Nuchterlingen, die de stof waaruit de legende is opgebouwd meenen te herkennen in oud-testamentische apocriefen, in de boeken der Maccabeeën en in legenden als van Onias en Ebed-mélech, zullen 't er minder op aan vinden komen, welk geografisch punt de legendedichter in het spel zijner verbeelding bedoelde te betrekken.

Maar John Koch, die verband legt tusschen Aesculaap-vereering en Kabiren-cultus, en latere christenvervolgingen, aanvaardt Ephesus; en dat sommige Moslimsche schrijvers het hol der Zeven Slapers elders zoeken, verklaart hij uit de verbreiding oudtijds van den Kabirendienst rond de Middelandsche Zee.

Wie over de Zeven Slapers veel wetenschap van vermeende wetenschap begeert, uit vele landen, talen en eeuwen, kan terecht bij P. Michael Huber O.S.B.: „Die Wanderlegende von den Siebenschläfern, eine literaturgeschichtliche Untersuchung", Leipzig 1910.

Huber's onderzoek evenwel strekt zich niet uit tot NederlandschIndië, waar óók teksten voorkomen - Maleische, Javaansche, Bataksche, Atjèhsche - die op de Zeven Slapers betrekking hebben.

In „De Koranische verhalen in het Maleisch” (Tijds. Ind. T. L. en Vk., dln 35 en 36, 1892/3) handelt Gerth van Wijk op pp. 633 e.v. dl 36 over ,De zeven slapers in de spelonk: Ashaboe'l kahfi wa al Rakim. Koran XVIII" (er staat abusievelijk XXIII).

Dit stuk bevond zich onder de Maleische geschriften van $H$. von de Wall, in het bezit van het Bataviaasch Genootschap, Nos 67 en 68, geheeten „Kisasoe'l anbia” en „Hikajat Radja Firaoen”.

Het verhaal kwam ook voor in een in 1859 te Batavia bij De Lange uitgegeven Javaansche „Kitab Ambija” met titel „Tapĕl Adam”.

Eenige verschillen tusschen de Javaansche en Maleische versies noemde Gerth van Wijk in Aanteekeningen 132/134 op pp. 698/699.

Zooals Brandes meedeelde in hetzelfde periodiek dl 41 (1899) op p. 297, had Van der Tuuk onder de verhalen van de groote „Hikayat Baktiyar” een vertelsel opgeteekend „Van drie mannen in een hol, dat door een vallende rots gesloten werd, en geopend door weldaden, die zij bewezen hadden".

Zoo'n vertelsel ontmoeten wij ook in het "Maleische Leesboek” door Chr. A. van Ophuysen (Leiden 1912) op pp. 71/75: „No 39. Tiga orang didalam goea”. Prof. van Ronkel lichtte mij in, dat Van Ophuysen het verhaal ontleende aan een tot de nalatenschap van zijn vader, den oud-resident van Ophuysen, behoord hebbend manuscript „Raudat al 'oelamiās", thans in de Universiteitsbibliotheek te Leiden 
(Oph. 145. $8^{\circ} .153$ bl. 13 r. Vide „Suppl ${ }^{t}$ Cat $^{s}$ Mal. en Min. handschr. i/d Leidsche Ut"bibl" door $\mathrm{Dr}$ Ph. S. van Ronkel. 1921).

In dl 46 (1896) „Bijdragen t/d T. L. en Vk. v. N. I.” signaleert Dr van Ronkel in zijn „Account of six malay manuscripts of the Cambridge University Library" een Maleische commentaar op Soerah XVIII, waarin van de Zeven Slapers in de Spelonk zeer uitvoerig wordt verhaald.

Dr P. Voorhoeve noemt in zijn akademisch proefschrift „Overzicht v/d Volksverhalen der Bataks” (1927) onder No 224: „Zeven makkers, in een grot opgesloten, doen deze opengaan door het verhaal van hun goede daden". Dus geen Zeven Slapers en geen Drie Hollemannen, doch een combinatie: het aantal van de Slapers, maar de kwaliteit Holleman.

Op het 20ste internationale Orientalistencongres, in September 1938 te Brussel gehouden, werden de Zeven Slapers ook genoemd. Prof. van Ronkel deed er mededeelingen over een 16de eeuwsch, in Arabische karakters gesteld manuscript uit de Nationale Bibliotheek te Madrid, het éénige Indonesische stuk, dat Dr G. F. Pijper in Iberië had aangetroffen.

Het was gesteld, voor een deel in het Maleisch, voor een ander deel in een Philippijnsche taal, kennelijk door een handelaar, die er, behalve mercantiele notities, ook aanroepingen, tooverspreuken, magische kwadraten en mystische formules in slecht Arabisch in had neergeschreven. Zoo compareerden daar ook twee maal: de Slapers, onder de namen Maksalimina, Mahsalimina, Tamlicha, Marțoenis, Kasjṭoenis, Bajroenis, Dajboemis, Mațioenis en Kaloenis, en de bijbehoorende hond draagt er den naam Kițmir en een ander maal Kițirah.

Van het voorkomen van de legende op Atjèh blijkt uit Snouck Hurgronje's „De Atjèhers”, dl II, p. 173.

Onder de godsdienstige werken der Atjèhers, speciaal de legenden over den vóór-Mohammedaanschen tijd, staat daar onder LVII de „Hikajat Tamlikha” of „Ëëlia toedjōh”, waarvan wordt gezegd:

In het 18de hoofdstuk van den Qoerān wordt de geschiedenis der zeven slapers behandeld. De Moslimsche overlevering noemt een hunner Jamlich $\bar{a}=$ Jamlichus, waaruit de Atjèhers Tamlikha gemaakt hebben.

Nog erger dan deze naam zijn die der zes anderen verknoeid; 
de namen dezer ,zeven heiligen" en van hunnen hond gelden intusschen in Atjèh als adjeumat's (amuletten), die alle onheil afweren en allen zegen brengen.

De hikajat geeft zoowel het verhaal van de drie vromen in de grot, dat de Qoerāncommentaren naar aanleiding van Qoerān 18:8 opdisschen, als de overlevering omtrent de zeven heiligen en hunnen hond. Behalve de verknoeiing der namen biedt de Atjèhsche bewerking nog twee noemenswaardige eigenaardigheden.

Vooreerst wordt het verhaal Ali in den mond gelegd; de schoonzoon des profeets deelt het mede op verzoek van eenen Jood, die zooeven tot den Islam bekeerd is, nadat Alî hem een aantal theologische strikvragen, waarop Oemar tot zijne schaamte het antwoord moest schuldig blijven, heeft opgelost.

Verder wordt de in Qoerān 18 :20 vermelde ,twist” verklaard als een oorlog tusschen een Mohammedaansch vorst, die eene moskee bij de grot wil oprichten, waarin de zeven heiligen rusten, en een Christenkoning, die genoemde heilige plaats wil ontwijden door eenen tempel met een afgodsbeeld!

De omdooping van Jamlīchā in Tamlikha en de ,twee noemenswaardige eigenaardigheden”, waarop Snouck Hurgronje wijst, zijn niet specifiek Atjèhsch. In de aan Alî toegeschreven, door Tha'labī overgeleverde Arabische teksten en in de Al-Kisâî-redacties komt men ze ook tegen.

Hoe de naam van der Zeven-Heiligen hond in Atjèh als adjeumat dient, vertelde ook Van Ronkel in Tijdschrift voor het Binnenlandsch Bestuur Juli 1914, waar hij zeven „Brieven uit Atjèh” toelichtte en op p. 48 aanteekende, dat op de omslagen veelal mystieke letterteekens of namen waren aangebracht, om het terechtkomen in de goede handen te bevorderen. Zoo het teeken $K . T . M . I . R$. in nietaaneengeschreven letters, dat den naam Katmîr voorstelde van den hond der Zeven Slapers:

De naam van hun trouwen hond werd vroeger, en wordt door oude lieden nog, op den buitenkant van brieven geschreven, om verloren-gaan of in-verkeerde-handen-vallen dier schrifturen te voorkomen.

Curiositeitshalve moge hier nog vermeld worden, dat diezelfde naam door moslimsche onderdanen van den Czar in den Kaukasus en de landen oostwaarts gebruikt wordt op hun brieven in de 
beteekenis van ,aangeteekend”, welk teeken door de postadministratie ginds als zoodanig schijnt te worden aanvaard.

Van zoo'n gebruik vindt men ook al gewaagd in de „Voyages de $\mathrm{Mr}$ le Chevalier Chardin en Perse et autres lieux de l'Orient" (Amsterdam 1711), dl II, p. 301. Sprake is daar van bijgeloovige practijken van Perzische briefschrijvers; zoo:

que sur les lettres qu'ils mettent dans une enveloppe de papier, ils écrivent près du cachet trois fois le mot de Cratin, qui est un mot sans signification. Il n'y a rien de plus ridicule \& de plus fabuleux que la raison que quelques-uns en donnent. Ils disent que Cratin est le nom du Chien des Sept Dormans, desquels ils ont la fabuleuse Legende, comme les Chrétiens Orientaux \& les autres qui l'ont prise d'eux \& que ce Chien preside aux Lettres missives. Ils content que ce Chien étoit dans la caverne des Sept Dormans, òu il faisoit le guet pendant les trois siècles qu'ils passèrent à dormir; \& que quand Dieu les enleva en Paradis, le Chien s'attacha à la robe d'un de ces Dormans, \& fut ainsi enlevé en Ciel. Que Dieu le voyant là, lui dit: Kratim, par quel moyen te trouves-tu en Paradis? Je ne t'y ai point amené, aussi ne veux-je pas t'en chasser: mais afin que tu ne sois pas ici sans patronage, non plus que tes maitres, tu presideras sur les Lettres missives, \& auras soin qu'on ne vole pas la valise des Messagers pendant qu'ils dorment.

Kratim en Crati $n$ zouden zijn te verklaren uit een $K . T . M . R$. of K.T.N.R., waarin de $R$ per abuis uit het 4 de naar het 2 de gelid versprong (metathesis).

Michael Huber vermoedt nog een ander abuis met dien hond: die hond zou eigenlijk geen hond zijn, maar een eerst door het volk en dan door de Arabieren misverstane Syrische wakende Engel!

$\mathrm{Er}$ is veel onzekerheid in Huber's en anderer Zeven-Slapers-wetenschap.

Kan 't kwaad, zoo ik hun gissingen met nog één vermeer? Kan zou ik willen vragen - er mogelijk rasverwantschap bestaan tusschen Chevalier Chardin's paradijshond Kratim en den hond, dien Yudhishthira in den Hinduhemel introduceerde, en die zich daar als Dharma in hoogst eigene goddelijkheid ontpopte? Dharma - Wet aanwijzing nopens te volgen routes in handel en wandel - wetboeken - geschriften - brieven ... die begrippen laten zich wel associeeren. Verwantschap dus van Cratin alias K. R. T. M. alias K.T. 
M. R. en des trouwen Yudhishthira's getrouwen viervoeter óók naar scripturale en postale functiën?...

't Wordt tijd op den beganen Atjèhschen grond terug te keeren.

Daar gelden - hoorden we van Snouck Hurgronje - de namen der Zeven Heiligen en van hun hond als middelen, die onheil weren en zegen brengen.

Die namen en zinspelingen op hun dragers behoorden dan ook tot de papieren munitie van hen, die zich na 1896 verzetten tegen het hun opgelegd gezag. Wie om dit te ontloopen, het kustgebied verlieten en de bergen introkken, wilden wel weten, de voetstappen te drukken van de k̇ëlia toedjōh, die, wegvluchtend van den ongeloovigen koning Kianöih (= Dakianus = Decius), zich verscholen in een grot, waar God het wonder wrocht, dat zij insliepen, om eerst te ontwaken na 309 jaren, die hun waren als één nacht. Er was collegiale belangstelling voor die Heiligen en vraag naar hun voorbede, om gehoed te worden als hun was geschied; en hun historie, als vervat in de $\mathrm{Hi}$ kajat Tamlékha of Ė̈llia toedjōh of Aseuhabōj Kapi, was gewilde lectuur in de schuilplaatsen.

Een exemplaar uit een kamp in de Paja Tjitjém in Pasè kwam mij in 1910 te Idi in handen. Ik zond 't aan professor Snouck Hurgronje te Leiden. Zoo maakt 't thans deel uit van diens aan de Universiteitsbibliotheek aldaar vermaakte verzameling Atjèhsche handschriften: tekst A.

Een tweede, half-zoo-lange, en in de woordkeuze en zinswending hier en daar afwijkende tekst bevindt zich onder 't zelfde nummer $11 \mathrm{LX}$ in die collectie: een in 1891 te Koetaradja gemaakt afschrift: tekst B, waarvan onlangs óók nog een transcriptie in Latijnsche karakters werd aangetroffen.

Een vraag: hoe verhouden zich de Indonesische teksten, en wat is hun afkomst?

De voorhanden gegevens laten niet toe, méér te zeggen dan dat zij uit nog al verschillende Arabische- en mogelijk ook Perzische teksten schijnen te stammen, en vermoedelijk via Zuid-Indië hun entree in den Archipel zullen hebben gemaakt.

Maar de twee Atjèhsche teksten, waarop wij onze aandacht concentreeren, zijn kennelijk van één komaf. Tekst B met 25 pagina's en 600 versregels, is evenwel géén verkorting van A met 61 pp. en 1200 regels; eer zou A een parafrase kunnen heeten van B: B is trouw en sober in de weergave van een lezing, die over groote gedeelten van 
woord tot woord overeenstemt met Tha'labi's "Qiças al anbija", zooals Dr C. van Arendonk de goedheid had mij die uit het Arabisch over te vertellen, en zooals die ook staat weergegeven in Huber's „Textbeiträge zur Siebenschläferlegende des Mittelalters” (Romanische Forschungen XXVI 545-559). Namen van zegslieden en geografische aanduidingen als bij Tha'labi, zijn ook trouwer overgenomen in B dan in A, en van de verhaaltrant bij Tha'labi, waar Alî in zijn vertelsels telkens geinterrumpeerd wordt door een bijzonderheden wenschend joodsch pandita, is slechts in B een spoor terug te vinden.

A en B geven echter ook: onderling verwante prologen met inhoud waarvan bij Tha'labi nièts wordt aangetroffen, echter wèl in een handschrift te München, waarover Huber (p. 309) schrijft: „Nach Cod. Arab. 195 (München) werden die Siebenschläfer angerufen beim Suchen, bei Krieg und Brand, beim Weinen der Kinder, zur Fernhaltung von Dieben, von Schiffbruch, von Zorn und Ärger, zur Vermehrung des Verstandes". Voorts vertellen zij de vóórgeschiedenis van Kianòih, die in Tha'labi gemist wordt, daarentegen wèl voorkomt, zij 't wat anders, onder meer in te Weenen en München aanwezige Al-Kisâi-teksten (Romanische Forschungen XXVI 497).

Heeft de Atjèhsche dichter gewerkt naar nòg weer andere, verwante teksten, die onze arabisten nog niet gespeurd en ontgonnen hebben? Of is het voorbeeld geweest een Indisch? In Garcin de Tassy's Histoire de la Litterature Hindouie et hindoustanie wordt gewag gemaakt van vele "Quiças ulanbiyâ" en zelfs van vijf door Tirmizi (le Maulawî Mir Muhammad 'Ali de la ville de Tirmiz) in 1269 (1852-'53) te Cawnpûr uitgegeven masnawis, waaronder een ,Quissa-i-ashâb-i Kahf”. ... Maar dat zijn vraagstukken die liggen buiten mijn competentie.

Volge dan nu de hoofdschotel: de Atjèhsche teksten, waaraan ik vooraf doe gaan een overzicht van wat zij inhouden, alles met correspondeerende cijfers om de vergelijking te vergemakkelijken.

Vooraf zij dankbaar herdacht, hoe wijlen professor Snouck Hurgronje nu omstreeks tien jaar geleden aan de teksten met vertaling, zooals ik die hem toen vertoonde wel een aandacht wilde schenken, die leidde tot menige opmerking zijnerzijds, en even zoovele correcties door mij aangebracht. Veel dank ik den Meester ook in dezen arbeid. 
Op de bladzijden in A staan de versregels, waarvan hieronder de nummers worden aangegeven; in B redacties, welke correspondeeren met de naast de bladzijnummers aangegeven versregels van $\mathrm{A}$.

A

$$
\text { p. }
$$

p.

B

p. 1: r. $1-30$

2: $\quad 30-68$

3: $\quad 68-94$

4: $\quad 95-124$

5: $\quad 124-174$

6: $\quad 174-220$

7: $\quad 220-251$

8: $252-292$

9: $\quad 295-358$

10: $358-405$

11: $\quad 405-452$

12: $\quad 453-508$

13: $\quad 508-559$

14: $\quad 559-605$

15: $\quad 605-655$

16: $\quad 656-698$

17: $\quad$ 698-768

18: $\quad 769-869$

19: $\quad 869-942$

20: $\quad 942-977$

21: $\quad 977-1032$

22: 1032-1089

23: 1089-1133

24: $1133-1190$

25: $1190-1208$

25: $\quad 465-485$

26: $\quad 486-505$

27: $\quad 506-525$

28: $\quad 226-545$

29. $\quad 546-565$

30: $\quad 566-584$

31: $\quad 585-603$

32: $\quad 604-622$

33: $\quad 623-641$

34: $\quad 642-660$

35: $\quad 661-678$ 
416 DE LEGENDE VAN DE HEILIGE ZEVEN SLAPERS IN HET ATJÈHSCH.

A

p. 36: r. $679-697$

37: $\quad 698-718$

38: $\quad 719-739$

39: $\quad 740-761$

40: $\quad 762-781$

41: $\quad 782-801$

42: $\quad 802-820$

43: $\quad 821-840$

44: $\quad 841-860$

45: $\quad 861-880$

46: $\quad 881-901$

47: $\quad 902-921$

48: $\quad 922-941$

49: $\quad 942-961$

50: $\quad 962-981$

51: $\quad 982-1001$

52: 1002-1022

53: $1023-1042$

54: 1043-1063

55: $1064-1085$

56: $1086-1104$

57: 1105-1125

58: $\quad 1126-1143$

59: 1144-1163

60: $1164-1183$

61: $1184-1208$ 
In de teksten vallen vijf stukken te onderscheiden, op wier onderling verband aanmerkingen zouden zijn te maken :

I. een proloog, die eigenlijk enkel het straks te noemen vierde stuk inluidt;

II. het verhaal van drie vromen, gevangen in een grot, en de vertelsels van gewerkte goede werken, die zij vertellen om vrij te komen (naar commentaren op Ḳoerān 18/6);

III. geschiedenis van de bekeering van drie Joden met aanhang, naardien Moehammad's schoonzoon Alì weet te antwoorden op door één hunner, een pandita, gestelde theologische - althans theologisch opgevatte problemen, die Chalief Oemar niet aan had gekund;

$I V$. de door Alî op verzoek der bekeerlingen vertelde geschiedenis van de Zeven Heiligen en hun Hond: uitwerking van de Koeranische versie (18de hoofdstuk) van de Syrische Ephesus-legende;

$V$. de kwantitatief niet zeer belangrijke peroratie, die verband houdt met IV, een weerklank is van I, en openbaart de heilbrengende en onheilkeerende formule, waarvan de namen der Zeven Heiligen en hun Hond inzet en hoofdsubstantie uitmaken.

Eindelijk als appendix een rijmelarij van den copiïst: wànneer hij klaar kwam met de schrijverij, de belijdenis dat hij die niet gewend is en dus maar matig verstaat, en opgave van woonplaats en naam. Zoo althans in $\mathrm{A}$. 


\section{N H O U D.}

\section{Proloog.}

In naam van Allah, den Genadige en Barmhartige.

Er zijn zeven namen van hoogen adel, die naar het verhaal van Abas' zoon als voorbehoedende medicijn kunnen dienen. Naar het gebod van den Profeet dienen zij te worden geleerd aan de kinderen, om hen te beveiligen tegen gevaar en verre te houden de duivels.

8 In de (achttiende) soerah van den Koerān, getiteld „De Grot”, is daar alles over te vinden; daar wordt gehandeld over de zeven mannen met als nummer acht hun hond.

11 Wie (de namen van) de zeven grotlieden bij zich draagt is veilig.

12 Schrijft ge ze op uw woning, dan genezen er de ziekten en de rampspoeden wijken.

13 Pogingen tot brandstichting hebben geen succes, en dieven wagen het niet $\mathrm{u}$ overlast te doen.

16 Een vaartuig, daarmee geletterd, is verzekerd tegen schipbreuk, ook bij den hevigsten storm, want wervelwind en branding laten af.

20 Voor kleine kinderen, die maar al huilen, hebt ge slechts de zeven namen op een papier te schrijven, en dat bij hen te leggen of in het hoofdkussen te doen, en hun rustige slaap is verzekerd.

25 Landbouwers hebben, om een goeden oogst te krijgen, de edele namen maar te schrijven op een stuk hout in de juiste karakters, en dat te planten midden op de sawah; - dan is het uit met de plagen, en muizen en walangsangit's schaden niet meer.

28 Als medicijn tegen duizeling helpt het ook best, zoo geschreven op het juiste tijdstip en bevestigd aan de rechter hand.

31 Zoo ge een barende een met die namen beschreven brief boven de rechter dij bindt, komt het kind voorspoedig ter wereld.

36 Wie zich wapent met een stuk papier, dragend die namen, bevestigd aan de rechter pols, - diens betoog in de rechtszaal wordt steekhoudend, en hij wint zijn zaak vast!

39 Wilt het toch gelooven, draagt ze op uw hoofd, draagt ze steeds bij u en door 's Heeren genade blijven verre de gevaren.

41 Stelt bij voorbeeld de vorst $\mathrm{u}$ in staat van beschuldiging en treft $\mathrm{u}$ zijn toorn, - wanneer ge dan voor hem verschijnt, zorgt dan zoo'n briefje bij $\mathrm{u}$ te hebben! stellig wordt u vergeven, en geweken is de boosheid. 
44 Geeft ge het briefje aan een kraamvrouw, dan durft de „boerōng” haar niet aan; Oemm aç-çibjān de kinderduivelin blijft op een afstand.

48 Groot is het nut van zoo'n briefje, onzegbaar groot! en daarom: in iedere woning hoort men het te hebben.

51 Kunt ge het niet zelf schrijven, betaalt er dan iemand voor, dat hij het voor $\mathrm{u}$ doe.

53 Laten de kosten u niet weerhouden, want anders, - hoe zoudt ge voordeel oogsten?

$60 \mathrm{Nu}$ ga ik vertellen van de heiligen, en, met den zegen mijns leeraars en volgens de richtlijnen der schriftgeleerden, veratjèhschen het hen betreffende Koerānverhaal. God geve, dat ik daarin slage, opdat de eenvoudigen van geest het gaan verstaan.

65 Bij de mirakelen van alle profeten geve de Heer mij een volmaakt godsvertrouwen, opdat ik huldige $\mathrm{Z}_{\mathrm{ijn}}$ woord, tot mijn stervensuur slaat en mijn ziel vervliedt. Moge ik dan nog, door den zegen van het Goddelijke woord, kunnen zeggen: „La élaha élalah”; want wie in den doodstrijd de edele formule indachtig blijft, ervaart Godes heil.

II. De drie vromen in de grot.

72 Drie mannen hebben verlaten hun dorp om rond te trekken in de bergen. Op eenmaal is het hun of de hemel neerstort op hun hoofden. $\mathrm{Zij}$ vluchten in een grot en deze sluit zich achter hen.

$78 \mathrm{Zij}$ overleggen en besluiten Gods hulp in te roepen en om die te verkrijgen, één voor één een verhaal te doen van een goed werk dat zij hebben gearbeid.

84 Nummer één verhaalt:

86 „Ik placht vroeger menschen te betalen om goede werken te doen, en daartoe gaf ik aanvangskapitaal en dagloon.

89 Eens kwam er een fakir van bij uitstek vroom uiterlijk, een zeer rechtzinnig man. Ik hield hem aan om Gode eer te bewijzen, een halven dag slechts, dan zou ik hem betalen het loon van een vollen dag.

$96 \mathrm{Na}$ een halven dag den Heer geloofd te hebben, ontving hij vol loon en ging.

100 Maar een fakir die al langer bij mij verbleef, toornde, omdat hij voor een vollen dag niet méér ontving. Hij liep boos weg en zijn loon liet hij staan. Voor dat loon nu kocht ik een koe, en ik verzorgde die, en de koe groeide uit tot een kudde, die het veld bedekte.

106 Jaren later kwam de man, oud en verzwakt, zijn éénen dag loon opvragen.

Deel 98. 
110 En ik betaalde hem uit: „Al die runderen” zei ik, ,zijn van u”. Hij meende dat ik spotte en verweet mij, dat ik geen deernis had met zijn hooge jaren; maar ik verzekerde hem dat alles van hem was, en vertelde de heele historie.

114 Dat is mijn goede daad o makkers. Van God ontvange ik daarvoor mijn loon.

115 Ja Heere mijn, hoor mij aan, ik deed dit voor U. O God, geef mij een uitweg. Mocht dit mijn werk liefdadigheid heeten, verlos ons dan nu uit de grot."

118 De woorden zijn nauw van de lippen, of de berg splijt, en eenig licht breekt door het duister.

\section{Dan vertelt nummer twee:}

123 „Indertijd heerschte er hongersnood in het land, en ik alleen had nog vol op. Toen kwam er een schoone vrouw mij vragen om voedsel tot stilling van haar honger.

132 Haar stem klonk zoo lieflijk en daarbij was zij zóó mooi, dat mijn begeerten werden gewekt. Dus zei ik: „Mijn verlangen gaat uit naar u o schoone. Wat ge wenscht zal ik u geven, mits ook gij mij schenkt wat ik begeer."

137 „Wacht even teungkoe, ik zal het mijn man gaan vragen. Vindt hij het goed, dan kom ik terug."

139 Ze ging tot haar man en deze oordeelde: „Wat zou daar tegen zijn? Hij vraagt dat? wel, sta 't hem toe. Als onze kinderen maar niet sterven!" De vrouw keerde terug. In de zoojuist gestelde voorwaarde stemde ze toe.

145 „Kom dan gauw boven!” zei ik. En bij mij boven gekomen, ontblootte zij zich, en haar ledematen werden zichtbaar. $Z$ ij pakte haar kleed tezamen en zichtbaar werd haar lijf, en mijn driften laaiden hooger. Maar toen ik haar naderde, begon ze te rillen, een aardbeving gelijk. „Waarom ril je zoo?" vroeg ik.

149 „Omdat ik bevreesd ben voor den Heer.” Zij zei dat heel zacht, en met dat ik dat hoorde, voelde ook ik mij bezorgd worden. Mijn krachten weken en mijn hart werd bang, en op mijn vragen antwoordde zij :

156 „Teungkoe, ik ben erg bang, want zwaar zijn de hellestraffen. Ik beef uit vreeze dat de Heer zal toornen; wat thans genot geeft zal in het hiernamaals gestraft worden."

159 „Uw geloof is inderdaad zeer hecht!” zei ik, en nadat ik dat gezegd had, werd ik ook heel angstig. Ik vreesde voor God, en ongerustheid beving mij.

162 Ik bedekte de naaktheid, het kwam tot niets, snel verwijderde ik mij, en 
ik had berouw en gaf een zoenoffer, omdat de schaamte was ontbloot geweest.

165 De vrouw schonk ik een gift, waarop zij ging en huiswaarts keerde tot haar echtgenoot. Dus was mijn werk. Was het een góéd werk, moge dat dan blijken! O Heer hoor mij aan, aldus handelde ik om U. Zoo Gij dit mijn werk aanvaardt, mogen wij dan vrij komen en naar buiten kunnen!"

169 Nauw heeft hij gesproken, of de berg gaat verder open en het wordt licht; de zon wordt zichtbaar en haar glans doorlicht de heele grot, en naar buiten kijkend zien zij van alles, alom spreidt zich het licht. Maar toch kunnen zij nog niet naar buiten; nòg blijven zij in zorgen in de grot.

173 De derde man vertelt:

174 „Ik heb indertijd hulde bewezen mijn ouders. Zij waren zeer oud en ik werkte voor de kost. Ik verdiende met geitenhoeden hun onderhoud. Iederen morgen melkte ik en 's ochtends en 's avonds bracht ik hun de melk thuis. Ik spande mij wel zeer voor hen in.

179 Op zekeren dag gutste de regen neer tot het avond werd, en in den donker kwam ik thuis, $\ldots$ beide mijn ouders sliepen vast. Ik wachtte, de melk in mijn handen, tot zij wakker zouden worden; den heelen nacht stond ik daar, maar niemand werd wakker. Ik was niet weinig bezorgd, en de kom met melk hield ik op tot 't dag werd.

185 Ik stond daar alleen in den nacht, bevreesd dat zij mogelijk boos zouden worden. In den vroegen morgen ontwakkten zij. Vader stond op, zag mij, en schielijk reikte ik hem de kom. Hij dacht, dat ik zoo juist was gekomen, nam de kom, ging daarmee naar beneden, zette de melk weg, en ging sembahjang.

190 Ik ging toen meteen naar beneden om met vader de kleine ritueele wassching te verrichten. Vader, moeder en ik, dag en nacht loofden wij God, en steeds ná de sembahjang ging ik om loon werken bij rijke lieden. Ik onderhield hen beiden, en geen dag dat ik niet uittrok om te verdienen, en hun sirih, pinang, rijst en visch te verschaffen; ochtend en avond was ik in touw.

195 Ik kocht kleeren en baadjes, dat zij zich niet hoefden te schamen voor de omwonenden. Destijds was ik zeer ijverig, en ook voor zout en voor licht zorgde ik. Ik verdiende met geiten te hoeden en doolde daartoe door alle dorpen, maar op de gestelde tijden verrichtte ik de sembahjang en loofde ik den Heer. Omdat mijn lot moeilijk was, ging ik waar rijkaards waren, om hun geiten te hoeden; vervolgens zocht ik mijn ouders op.

201 Toen hun tijd gekomen was en zij de eeuwigheid ingingen, zorgde ik voor 
hun begrafenis. Aldus mijn werken toen ik nog jong was. Moge ik daarvoor thans vrij komen en naar buiten kunnen!

205 Ja Heere mijn, hoor mij aan, ik deed het voor U. Indien goed was deze mijn arbeid, moge ik dan nu vrijgelaten worden o Heer!"

207 Als dit is uitgezegd, opent zich de berg en zijn zij vrij, en ingevolge Allah's voorbeschikking treden de jongelui gedrieën naar buiten.

211 „Rakim” wordt gezegd te beteekenen „leisteen”. De „Spelonkmannen” staan daarop geschreven, en bewaard bleef die lei aan den grotingang in een kist. Aldus één verhaal.

\section{Bekeering van drie Joden.}

214 Van de spelonkmannen is het dat ik nu vertel.

215 De geschiedenis speelt in de dagen van ná Jezus en vóór Moehammad. Menschen van de Thora (d.z. Joden) vertelden ze, en aangehoord werd ze door Oemar.

217 Drie Joden komen bij Oemar en stellen vragen. Weet hij die te beantwoorden, dan willen zij zich tot den Islām bekeeren.

238 Het lukt Oemar niet.

241 De Joden hoonen dat Moehammad geen profeet is en zijn leer enkel bedrog.

247 Zekere Salmān Fārisī vat vuur: „Wacht even Joden, daar komt onze heer Ali aan!' De Joden worden stil. Oemar blij, staat op, en vat Ali's hand.

253 Ingelicht wat de Joden wenschen, moedigt Ali hen aan vrij uit te vragen. Onderwezen door den profeet, zal hij hen weten te staan; maar hij conditionneert: zij zullen zich dan bekeeren!

266 Dat wordt aangenomen.

273 „Wat is het slot des hemels?” luidt de eerste vraag.

„Allah genooten toe te kennen (polytheïsme). De sleutel op dat slot is: de geloofsbelijdenis!"

281 „Een mobiel graf met inhoud, wat is dat?”

„Dat is de visch die den profeet Jonas inslikte!”

288 "Geen geest en geen mensch, rara wat is dat?"

„Dat is de mier Namlah van den profeet Salomo!"

292 „Welke vijf wezens zijn niet geboren uit hun moeder?”

„De profeet Adam, de kameelin van Salèh, de ram van Abraham, de mier van Salomo, en ons aller stammoeder Eva!"

300 "Wat is de beteekenis van het haangekraai?"

„De haan klapwiekt en maakt de ritueele buiging om te prijzen den Heer, 
en den kop buigend zegt hij: „Odkoer oelah minal rafilin!” (= Gedenkt Allah o onverschilligen!); daarmee waarschuwend den mensch, dat hij indachtig zij aan God en niet opga in het aardsche. Let op, hij gedraagt zich deemoedig in het spreken, aldus waarschuwend, dat wie zich vergeten, ter helle varen."

319 „Wat beteekent het gehinnik van het paard?”

„Het hinnikende paard zegt: O God, steun de Moslimsche aanbidders tegen de ongeloovigen."

325 ,Wat kirt de duif?”

„De duif vloekt wie belastingen heffen: adat glé, wasé en adat koeala."

334 „En de kikvorsch?”

„Deze zegt maar aldoor de tasbīh-formule ,soebhāna 'llāh" ter verheerlijking Gods. Het laatste derde deel van den nacht is hij daar steeds mee doende."

342 De Joden, hoorend de antwoorden van Ali, spreken uit de twee kalimah's. Alle drie worden zij Moslims door goddelijke ingeving, en mèt hen gaat een heele stam van schriftgeleerden over tot den Islām.

350 Bekeerd, hebben die schriftgeleerden méér nog te vragen: Eertijds zouden zeven mannen en één hond driehonderdnegen jaren ná hun dood in een grot zijn gaan herleven. Wil Ali hun daar de bijzonderheden wel van vertellen?

$365 \mathrm{Na}$ even te hebben nagedacht, antwoordt Ali, navertellend het zeggen van den profeet.

\section{De zeven Heiligen en hun hond.}

367. Vermeld staan in den Koerān de trekken van de zeven Grieksche spelonkmannen uit Akeusoeih (bedoeld Apeusoeïh: Afsus: Ephesus), die ná den vromen Malik Salèh, Kianòih (: Kianos: Dakianos: Decius) meemaken, den ellendigen goddeloozen vorst, den Pers, die het van geitenhoeder tot vorst bracht.

375 Als geitenhoeder schuilde hij onder een grooten boom, waarheen ook kwamen de dorstige geiten. Daar gravend naar water, ontdekte hij een kist die fraai geschreven documenten bevatte.

384 Kianos nam ze mee naar de meunasah en vroeg daar een stokouden geleerde om hem de teksten te verklaren.

395 De grijsaard (in B 393700 jaren oud, in A een overlevende uit Mozes' dagen) zag dat de brieven, gesteld in de oude taal van Mozes (B noemt 't Hebreeuwsch), handelden over koning Karōn (= Korach), die twaalf huizen vol goud had bezeten, maar mèt zijn goud door de aarde verzwolgen was, als gevolg van Mozes' vloek. 
400 Gelast zakat te betalen, om God niet te berooven, had Karōn, inplaats van naar den profeet te luisteren, dezen beticht van hoererij. Dat was de reden geweest van Karōn's ondergang. Twaalf putten waren met zijn schatten geheel gevuld.

405 „Waar zijn die putten?” vroeg Kianos, „,an graaf ik ze uit en we deelen samen."

406 De geleerde wees de plaatsen. Achteraf werd Kianos spijtig, en belust alles alléén te hebben. Hij trilde als een aardbeving, liep naar huis, en riep zenuwachtig zijn vrouw toe: „Geef gauw een spa! Ik wil die meenemen in het veld om putten te graven. Er is nergens meer water voor de geiten."

414 Met de spade ging tegen het begin van den tijd voor de avondgodsdienstoefening Kianos er op uit.

415 Halfweg ontmoette hij den duivel, die aan den weg zat in de gedaante van een schriftgeleerde. Hij hield Kianos staande:

421 „Keer terug en dood dien ouden man; dan hoef je dat goud niet met hem te deelen!"

426 Kianos liep terug naar de meunasah en trok zijn zwaard om te houwen naar den wijze. „Dood mij niet Kianos” riep deze, ,dat goud begeer ik niet!” Maar Kianos geloofde hem niet: „Als ik vannacht dat goud uitgraaf, dien jij morgen een vordering in!" en woedend en met rood gezicht stak hij toe.

435 De tijd was goed gekozen: niemand die wist dat hij den sjeich had dood gestoken. Later pas werd 't bekend, toen Kianos reeds als vorst regeerde, en toen gaf 't niet meer.

438 Den nacht van het sterven van den sjeich groef Kianos al het goud uit. De helft schonk hij den vorst, om niet gedood te worden in weerwraak.

440 De vorst loonde Kianos' gulheid met een befaamd vorstelijk lustgebied (Ephèsus, volgens B). Daar vestigde hij zich, en groot was nu zijn bezit en velen waren zijn onderdanen. Toen ging hij oorlogen. Dorp voor dorp en land voor land werd door hem overwonnen en ten slotte nam hij 't op tegen den vorst.

447 De vorst delfde het onderspit en de koningin, de havens en het land, alles viel Kianos toe. Nu bouwde Kianos een paleis van groote afmetingen en schitterend van goud en edelsteen. Daarbinnen stonden in het ronde, op gouden banken, lampen, gevuld met olijfolie - o verkwisting! en iederen nacht was het illuminatie.

456 Gouden drachmen deed hij slaan ter zwaarte van tien „mas”,en van de oude munt liet hij geen stuk in omloop.

460 In het paleis was een met juweelen bezette gouden troon van tachtig bij tachtig hasta, geflankeerd links en rechts door gouden stoelen voor 
hoofdenzonen en schoone hofjuffers, en krijgsoversten, vizieren en ministers hielden den vorst gezelschap, allen met gouden kronen op het hoofd. Vijftig kinderen, goed van handel en schoon van wezen, gekleed in groen, geel, rood enz., hielden gouden staven met kostelijke briljanten.

473 Onder die vijftig waren zes kinderen van schriftgeleerden. Hen had Kianos aangesteld tot vizieren, en de bedoeling daarbij was deze: Hij wenschte te laten zeggen dat hij God was, en als de zes knapen daarin vóórgingen, zouden anderen gemakkelijk volgen!

485 Tot op dat oogenblik was het zestal steeds om en bij hem geweest, drie links en drie rechts, getooid met gouden en zilveren opschik, dien hij hun had geschonken om hen willig te maken; de drie links met vogels, en de anderen met reukvaten waaruit djeumpa- en andere geuren opstegen en tot welker vulling de vogels de ingrediënten aandroegen. Hun veeren doopten zij in reukwater, en, vliegend tot boven den vorst, klapten zij met de vleugels, zoodat de vorst bedauwd werd met fijngeurende olie.

511 Vele waren de genietingen van den ellendigen vorst; alles had hij; wat hij vroeg, dadelijk was het er. De vogels in de lucht had hij als dienaren, alle dieren waren hem bevriend en verzamelden zich om hem heen. Hij had maar te kikken en hij kreeg alles zooals hij het wenschte.

516 Wijd vermaard was koning Kianos, vele landen waren hem onderworpen, steeds groeide zijn aanzien, en toen - ging hij zeggen dat hij de groote God was!

520 Dertig jaren had hij geregeerd en de zegeningen Gods op aarde genoten. Maar zijn geschiedenis loopt verder, en dit was eerst het begin.

525 Vóór hem waren er andere vorsten geweest, als Pharao, de zeer vermaarde; later Korach, die tot in het oneindige goud opstapelde; en Nimrod en 'Ad, booze vervloekelingen allen! Maar zij haalden niet bij Kianos! Duizend wegen stonden open voor diens verstand.

530 Zoo lang had hij al geregeerd en geen rampen waren hem nog wedervaren; hij wist niet wat hoofdpijn was, zag er nooit betrokken uit, had nog nimmer gehoest, was nog geen oogenblik duizelig geweest, had zelfs geen schurft ook maar gehad! de kafir-koning smaakte niet dan genieting; toen gelastte hij te zeggen dat hij God was, en zijn onderdanen riep hij bijeen en beval hun dat te getuigen, en.wie dat aannamen loonde hij in kleeren en in goed, maar wie niet in hem gelooven wilden sloeg hij dood. Dertig jaren had hij geregeerd en rampen waren hem geenerlei geschied; dàn echter was de ellendige vorst zijn ondergang nabij.

541 De zes knapen wilden hem dooden, maar zij weifelden en een minister waarschuwde: „U willen de oelama-zonen dooden. Zij noemen $U$ een 
ellendigen kafir, waar ge gelast te getuigen, dat ge de verheven God zijt!"

557 De vorst verbleekte, rilde, ging flauw op zijn troon; de kroon viel hem van het hoofd. Voor de eerste maal voelde hij zorgen. De oelama-telgen gelastte hij te dooden.

565 De zes knapen, eerst 's vorsten pages, en groot geworden zijn vizieren, heetten: 1. Tamlékha die uitmuntte in verstand, 2. Maksalémina, 3. Martoenis; dezen waren de ,ashāb oel jamin” die zaten rechts van den vorst. No. 4. was Nainoenis, 5. Sarboenis en 6 Faliastatajoenis, gedrieën uitmakend de ,ashāb oel sjimal" aan 's vorsten linker zijde.

580 Op het gezicht van den vorst las Tamlékha, dat de samenzwering was aangebracht. Het was dus zaak te vluchten. (Aldus in A. In B besluit men hem te verlaten, omdat men na die schrik-scène tot het inzicht kwam van zijn ongoddelijkheid).

585 Hij filosofeerde: „Als deze vorst God is, waarom is alles aan hem dan zoo menschelijk? Hij eet en drinkt als wij, er is niet het minste verschil. Neen, deze vorst is een mensch. Gods eigenschappen zijn anders. Maar men mag dat niet zeggen, of hij slaat je dood, de kafir-vorst, de vervloekeling. Wie zegt dat deze vorst geen God is, wordt aan den lijve gesneden en gespietst."

591 Zoo pikirde hij, en eten, drinken en slapen vergat hij en op zijn kleeding lette hij niet. Door zijn makkers gevraagd wat er aan schortte, gaf hij ten antwoord: „Ik dacht zoo: de hooge hemel wordt niet gestut, die hangt zóó maar. En wie beweegt zon en maan? Wie stelt de sterren? Wie geeft hun glans?

600 Waarom komen de bergen niet naar benee? Waarom vloeit de zee niet over het land? 's Avonds, waar wordt de zon dan opgeborgen? En als wij aan onszelven denken, toen wij nog ongeboren bij onze moeder verbleven, vanwaar kwam toen derwaarts het levensonderhoud? Wie maakte ons lichaam zooals het is? Kan deze vorst dat alles bezorgen?

$610 \mathrm{Hij}$ is aan ons gelijk, terwijl de heer God zijn weerga niet heeft. God heeft geen handen en geen voeten. De opperreine is Allah de verhevene, en deze vorst is een vervloekte ongeloovige. Wat hij ook beweert, gelooft hem niet! Gaat het aan, dat hij gelast te zeggen, dat hij God is? Hij heeft geen geloof, de ellendige kafir. In het hiernamaals zal God het hem loonen met het vagevuur!"

618 De makkers, hoorend wat Tamlékha zei, bewaarden dat in hun borst en antwoordden : „Zoo is het. Volgen wij den verdoemden vorst, dan vinden wij geen heil. Zeggen wij dat hij God is, dan zal de Heer met hem ons zessen folteren."

626 „Als we niet heengaan” - zei Tamlékha — „dan zal het niet lang duren 
of wij worden gedood. Iemand moet ons hebben beluisterd (lezing A natuurlijk!) De ongure koning kijkt zuur. Ons komplot moet zijn verraden (lezing A), en daarom zeg ik: we moeten den duivelschen vorst verlaten en ons wenden tot den Heer, den Schepper van Hemel en Aarde."

638 Om zich reisgeld te verschaffen verkocht Tamlékha een boom voor drie Perzische drachmen van tien mas. Daarop tuigden zij hun paarden op en met hun zessen reisden zij af. Toen de goede weg ophield, besloten zij den tocht te voet voort te zetten, met achterlating van de paarden die eigendom waren van den vorst.

652 Zeven parasangen waren zij gegaan, toen bloedden hun voeten die het loopen niet gewend waren. $\mathrm{Zij}$ ontmoetten een geitenhoeder met rein gemoed. Groeten werden gewisseld, de knapen vroegen te eten en te drinken en werden onthaald op geitemelk, rozijnen en dadels.

666 Den nacht bleven zij over en in de avonduren werd er gepraat. De herder zei in zijn gasten best hovelingen te hebben herkend, vroeg vanwaar zij kwamen, waarheen zij wilden en wat hun aanleiding had gegeven zoo op reis te gaan.

676 Het zestal vertelde nu te zijn weggeloopen van koning Kianos, die een godsdienstlooze ongeloovige was geworden, voor God zelf wilde worden gehouden, en doodde wie hem zoo niet zagen.

688 De geitenhoeder sympathiseerde met hen en wilde mee de bergen in, om daar ascese te doen. Hij stelde zich voor als Doe Noeanis.

697 De hem toevertrouwde geiten bezorgde hij den eigenaren terug.

700 Met het zestal begaf hij zich op weg, en als nummer acht sloot zich aan des herders hond, een mooie hond van veel kleuren; wèlke kleuren, daarover zijn de geleerden het al even oneens als omtrent zijn naam.

713 Genoemd worden de namen Katmir of Kitmir, Diarah, Hamran, (Salam) Sabeuti, Takeuta, Kațimoen; maar volgens Abas' zoon heette hij Katmir.

745 Ze gingen op weg, de zeven mannen, en achter hen aan liep de hond. Kwansuis snauwden ze tegen den hond. Tamlékha zei: „Laten we Katmir niet meenemen! dat staat niet als die meegaat. Vinden jelui hem passend gezelschap?”

750 „Laat hij maar meegaan!” antwoordden de zes, maar de eigenaar zei: „Bulder maar wat, dat hij terugkeert!" Katmir, dat hoorend, kroop over den grond, en zei weenend: „Laat mij niet achter, neem mij toch mee!” en hij reciteerde: „Er is geen God dan Allah, en met den profeet Mozes heeft God gesproken. Ik getuig, dat God, mijn Heer, niet is als zijn dienaren. Hij heeft geen handen en geen voeten. Opperrein is de verheven Heer. Ik getuig, dat Mozes waarlijk de profeet is en dat het de geboden Gods zijn die hij gelast te werken. Mij hier moet ge niet achterlaten! Ik 
wil waken over $\mathrm{U}$ allen. Ik bid God, dat sterk moge zijn Uw aller geloof, dat de booze vorst $U$ zevenen niet vinde! Moogt ge in deze wereld en in het hiernamaals zegen erlangen en nergens gevaren ontmoeten en moge de Heer U het paradijs in leiden!" De hond had zich hiermee zijn plaats als no. 8 van het gezelschap verzekerd.

765 Gezamenlijk trokken zij bosch en bergen in, tot zij kwamen aan een schoone grot, in A Ramét, in B Wasit geheeten, in den berg Djabal Choeloes. Door die grot van albast stroomde een beek met kristalhelder bronwater.

770 De ingang was nauw zichtbaar, maar daarbinnen was het ruim, en daar groeiden rozijnen en dadels, die er rijpten aan den boom, en tjéndana's spreidden heerlijke geuren.

776 De zeven mannen gingen binnen, de hond betrok de wacht aan den ingang.

782 En God zond den doodsengel Azrail om hun zielen te nemen, waarop zij bezwijmden.

789 Katmîr lag aan den ingang zonder meer honger of dorst te voelen. Aan de engelen uit den hemel werd gelast de doode lichamen te verzorgen, twintig engelen per doode. Den 10den Moeharram van ieder jaar keerden zij de lichamen, met het oog op de mieren en tegen het bederf, en God liet de zon zóó schijnen, dat bij zonsopgang de dooden van rechts werden beschenen en bij dalende zon van links.

$805 \mathrm{Nu}$ keert het verhaal terug tot den koning. Missend zijn pages, vroeg hij waar het zestal was. Hij vernam, dat men hen had zien uitrijden in de richting van het gebergte, en waar zij nòg niet terugwaren, leek het wel, dat ze een anderen meester waren gaan zoeken. Sinds de vorst was gaan beweren God te zijn, schenen de knapen gedrukt. „Wij gelooven dat zij zijn uitgeweken!" zeiden anderen, en er waren er, die hen had willen tegen houden en doodslaan, maar geen hand hadden ze kunnen uitsteken, geen voet verzetten, geen mond opendoen!

826 De vorst mobiliseerde de bevolking om het zestal op te sporen. Zeven dagen lang verzamelde hij zijn menschen en tachtigduizend paarden zond hij uit. Maar de menschen overlegden: „Zij zijn uitgeweken, omdat de vorst zich God wou laten noemen; dáárdoor voelden zij zich bezwaard. Was de vorst God, dan zouden zij, oelama-zonen, stellig niet zijn heengegaan!"

837 Zoo was de heimelijke gedachte, maar geuit werd die niet, bang als men was te worden gedood. Er was veel innerlijke tweestrijd en veel meeningsverschil; natuurlijk: men verkeerde nog maar in de dagen van de „,djāhilijjah", de wetenschap was maar beperkt.

857 De sporen van de vluchtelingen voerden tot voor de grot. De hond, be- 
vreesd voor die menigte menschen, week even op zij; het volk kwam tot vlak aan den ingang. De groote hoop bleef buiten, een deel ging de grot binnen. Maar die binnengingen hadden zoo hun vermoedens: den vorst hielden zij niet voor God!

$869 \mathrm{Zij}$ troffen de vluchtelingen ,slapende” zoo zij meenden, en Allah gaf hun in, om buiten te vertellen, dat zij de knapen niet hadden gevonden; zulks ter voorkoming dat de vorst hen zou spietsen en verbranden.

888 Bang dat de slapers, wakker geworden, zouden schrikken en naar buiten vluchten, om te worden gevat en aan den koning overgeleverd, verlieten zij stil de grot, en vertelden buiten, dat er daarbinnen geen spoor van de vluchtelingen viel te bekennen. Zoo keerde men bij den vorst terug met de boodschap, dat men het zestal niet had aangetroffen.

902 De dagen gingen en de zaak raakte in vergetelheid, en Kianos was lang gestorven, toen de zeven man nog maar steeds leefden.

906 Driehonderdnegen jaren gingen voorbij, vele koningen waren elkaar opgevolgd, koning Schedel gestorven en profeet Jezus ten hemel gevaren, toen tijdens de regeering van Abdoel Rachman de Heer den zeven mannen hun ziel terugvoerde in het lichaam, waarna allen op èènmaal ontwaakten.

920 Ze richtten zich op en ziende dat de zon al hoog stond, verwonderden zij zich : ,We hebben God heelemaa! vergeten, zoo vast hebben we geslapen!” z.ei Tamlékha, ,de sembahjang is er glad bij ingeschoten!” $Z$ ij stonden op, wreven zich de oogen uit en liepen heen en weer, zoekende naar water, maar de beek was droog, de boomen dood en zonder blad, enkel de stammen waren over. Ze begrepen er niets van. Ze hadden honger en dorst, maar vonden zoomin rozijnen en dadels als water.

935 Tamlékha had geld gelukkig. Hij kleedde zich en ging uit om te fourageeren. Buiten gekomen keek hij vreemd op. Hij vond de wereld veranderd. Weg en marktplaats waren niet te herkennen. Hij zag een plein, en tot zijn verbazing las hij boven de toegangspoort de spreuk „Er is geen God dan Allah en Jezus is de geest Gods."

949 Hij vroeg een man, Chabaran geheeten, hem den weg naar de markt te wijzen. Chabaran loodste hem, en getweeën gingen zij er binnen.

957 Hij vernam dat de stad Akeusoeih (= Apeusoeih = Ephesus) heette en de vorst Abdoel Rachman. Verbazing! Tamlékha vroeg zijn mentor eten voor hem te koopen en gaf hem daartoe een drachme. Een drachme van tien mas gewicht! „Waar kameraad heb je dien schat gevonden? Halfje mijn, òf ik vertel het aan den vorst!"

968 Tamlékha zwoer niets gevonden te hebben. Een boom had hij verkocht, 
omstreeks drie dagen geleden. Daarop had hij de stad verlaten om den onheiligen vorst Kianos niet te hoeven aanbidden.

972 Zijn gehoor meende dat Tamlékha opsneed: 309 jaar geleden was de vorst dien hij noemde gestorven! Het werd een relletje op de markt en koning Abdoel Rachman hoorde ervan. Hij wilde Tamlékha zien, en deze werd voorgeleid en een menigte menschen kwam mee.

980 „Hoe komt die man zoo hier?” vroeg Abdoel Rachman. „Op de markt werd hij aangetroffen in het bezit van een oude drachme, die hij ontkent gevonden te hebben. Hij wou daar inkoopen mee doen, maar hij moet wel vast een schat hebben ontdekt. Wie weet hoeveel potten! en dan moet de vorst daar immers een vijfde deel van hebben?!"

990 Tamlékha, door den vorst ondervraagd, verzekerde geenerlei schatten te hebben gevonden. Hij had alleen maar drie drachmen ontvangen, in betaling van een boom, dien hij \pm 3 dagen geleden had verkocht, toen hij uitweek voor den onheilsvorst Soeltan Kianos, koning van Perzië, die met verzaking van het goede geloof, gelast had, dat men hèm God zou noemen, op poene van te worden gespietst en verbrand.

1000 Wij vluchtten het bosch in, en in de grot Wasét op den berg Djabal Choeloes verborgen wij ons. Dat is nu drie dagen geleden. Eén nacht sliepen wij daar en toen ik wakker werd kwam ik hierheen. We hebben honger en er is niets te eten. Daarom ging ik naar buiten. Mijn makkers bleven achter, en ik liep naar de markt om te fourageeren. Wij ressorteeren onder den heer van Ephesus en hooren thuis in deze stad. Wij waren pages van den ongeluksvorst, maar toen hij voor God wou worden aangezien, hebben wij hem niet gehuldigd doch zijn het bosch in gevlucht. Koning Kianos is inderdaad een groote verdoemeling. Velen heeft hij ongelukkig gemaakt. Vroeger hoedde de vent geiten en in eens - niemand begrijpt hoe - is hij koning geworden.

1012 Vergeving Heer, ik wilde graag weten of het huis er nog staat van Ibnoe Chatin, mijn ,bapa” die hier woonde dicht bij den vorst en wiens ouders ook hier thuis hoorden. Hij was uit Medinah en verhuisde naar hier in de dagen van Malik Saleh. Die vorst werd bij zijn overlijden opgevolgd door een ander, en onder den boozen vorst ging de godsdienst te niet." Tamlékha duidde de ligging aan van het huis, en de vorst stond paf. Hij liet Tamlékha geleiden naar de bedoelde plaats en veel volk trok mee. Bij het huis gekomen werden de bewoners naar beneden geroepen.

1025 Een oude heer kwam te voorschijn. Zijn hoofdhaar was dun: hier en daar nog een plukje, maar wit als katoen. De rug was gebogen, het vel gerimpeld, de wenkbrauwen waren als borstels die de oogen zoowat bedekten. „Wie daar beneden roept mij ? Vanwaar komt hij en hoe heet hij ?” „De 
soeltan stuurt ons met dezen jonker, die zegt dat dit huis niet van $U$ is. Hij heeft het pàs verlaten zegt hij. Wie heeft $U$ gezegd hier te gaan wonen? U zult zich moeten wegscheren! Dit huis is niet van U!'

i037 De oude werd woedend, zijn oogen fonkelden: ,Zeg eens, hoe heet je? Als je afkomst en staat kunt bewijzen, zal ik moeten aftrekken! Je schijnt geen klein beetje knap op het punt van bedriegerijen en je durft! Zeker, ik zal je mijn huis geven! Je hebt heel wat streken op je kompas! Sinds mijn overgrootvader stierf, is dit huis van mij. Wat beteekent dat zeggen van den vorst?"

1043 Tamlékha zei : „Hier woont Tamlékha, zoo heet ik, en dit huis is de voorouderlijke woning. Ibnoe Chatin is mijn vader. Eergisteren trokken wij het bosch in en vader bleef toen achter. Radja Kianos - hij zij vervloekt - beweerde dat hij God was, en wie dat niet aannamen spietste hij of hij sneed hun de tong uit en hun lijk wierp hij in het vuur. Wij vluchtten de bergen in en gingen de grot Ramit van den Djabal Choeloes binnen."

1052 Toen de grijsaard dat hoorde werd er een herinnering wakker en hij verwonderde zich: „Wat praat je van (eer)gisteren? dat is zéér oude geschiedenis! Die vorst is al 309 jaar lang dood. Ik herinner mij dat alles niet meer zoo precies." Maar op eenmaal schoten hem de feiten te binnen en de oude boog voor den jonker en bewees hem eer. Hij herinnerde zich dat verdwijnen van die jongens; vroeger had Jezus wel verhaald van de zeven in de grot, en dat zich herinnerend knielde de grijsaard voor de voeten van Tamlékha en kuste diens handen: In Tamlékha herkende hij den verdwenen broeder van den vader zijns grootvaders.

1064 Algemeene huldiging van Tamlékha volgde en aan den vorst rapporteerde men het resultaat van de confrontatie. Ook Abdoel:Rachman maakte zich nu op om den jongeling eer te bewijzen. Op eenigen afstand steeg hij van zijn paard; hij vatte Tamlékha's hand en panglima's en hoofden volgden; allen brachten eerbiedige hulde. Men zat in vergadering bijeen, Tamlékha werd geëerd en men vroeg hem vergiffenis. De vorst informeerde naar de zes makkers. Tamlékha antwoordde dat zij nog in de spelonk verbleven. Dàt wilde de vorst gaan zien wat God daar in de grot had gewrocht! Met groot gevolg van hoofden en onderdanen begaf hij zich op weg.

1090 Nòg een radja ging mee: de radja Nasrani, ook met veel onderdanen en hoofden en soldaten. Zoo trokken twee vorsten de bergen in, de vorst der Islamieten en de vorst der ongeloovigen. Bij de grot gekomen vroeg Tamlékha, het volk niet mee naar binnen te laten gaan: zijn zes makkers mochten eens schrikken en, meenend dat Kianos gekomen was, zich te- 
weerstellen! Naar binnen gingen dus enkel de beiden vorsten en Tamlékha, Abdoel Rachman gebeden reciteerend, de vorst der Nazareners zwijgzaam.

1108 De zes man, door de vorsten ondervraagd hoe lang ze reeds in de grot verbleven, antwoordden: één dag, een halven dag, enz. De vorsten lichtten hen in dat zij een tuk van 309 jaren hadden gedaan, de booze koning lang dood was, en Jezus had geregeerd maar alweer ten hemel was gevaren.

1118 De uitnoodiging om met de vorsten mee te gaan naar de bewoonde wereld, werd afgeslagen. De zeven mannen bleven maar lievei in de grot.

$1130 \mathrm{Zij}$ richtten een gebed tot God: Om de zichtbare dingen dezer wereld gaven zij niet meer en zelf wilden zij nu ook maar iiever niet langer zichtbaar zijn... Toen ze hadden uitgebeden was hun ziel gevloden.

1137 De koningen verlieten de grot. De Islamietische ging terade met zijn volk en gelastte de zeven mannen te wasschen en van lijkwaden te voorzien. Vervolgens verrichtten de oelama's de passende sembahjang en in koor klonk het amin van de lippen der rajat's. Ook door fakir's werd er gebeden en duizende buffels werden geslacht, want buiten de grot richtte de vorst een kandoeri aan die zeven dagen duurde. Dan werd de ingang van de spelonk toegemetseld.

1150 De vorst der Islamieten stelde zijn lieden voor, ter plaatse een moskee te bouwen ter gedachtenis. Maar de vorst der Nazareners oordeelde, dat, waar de slapers gestorven waren in zijn, het Joodsche geloof, het aan hèm was een gedenkteeken te stichten, een kapel ter berging van afgodsbeelden.

1157 Beiden hadden zij volk bij zich met geladen geweren, en de grot lag op een grensgebied waarop beiden aanspraak maakten. Zoo gingen de geweren af; het werd een groote strijd, die ten slotte door de Islamieten werd gewonnen

1170 Op Tamlékha's graf verrees een moskee en al maar door wordt daar gewaakt. Tamlékha hoorde thuis in Byzantium, en de Byzantijnsche moskee heeft een diamanten spits met acht groote zuilen. De heele wereld gaat er ter bedevaart; aanhoudend stroomen de menschen toe om gedane geloften te lossen, en zoo wolkt er de rook maar steeds omhoog. De zeven mannen toch zijn zeer ,kramat”! God maakte hen tot groote heiligen. Zij zijn de heiligen die in Gods nabijheid verkeeren en wie hun voorbede verzoekt krijgt wat hij wenscht.

$1178 \mathrm{Na}$ het verscheiden van de zeven mannen stierf buiten de grot ook de hond, en door de wil van den almachtigen God is die hond wel vast het paradijs binnengegaan. De vorst deed den hond begraven op een plaats buiten de grot en buiten de moskee. 


\section{Besluit.}

1182 Uit is het verhaal van de spelonkmannen, waarnaar Ali door de Joden gevraagd werd. Alles heeft hij hun verteld en dan vraagt hij: ,Staat het zoo ook in Uw thora” „Net eender!” zegt de eerste Jood. „Laat ons nu den godsdienst van Moehammad ingaan, en bidt U voor ons." De Joden spreken de geloofsbelijdenis uit en omhelzen fluks den Islām.

1189 Nopens de spelonkvrienden zijn de vertellingen vele, al naar de oelama's die ten beste gaven, maar, zijn er onder de geloovigen tegenstrijdige lezingen, ieder meent het ernstig tegenover God, ieder is rechtzinnig jegens onzen Heer, ieder spreekt naar hij leerde van de oelama's.

1192 Tot zoover het verhaal van de spelonkmannen. Vraagt er verder de geleerden maar naar.

1193 Wie de zeven spelonkmannen bewaart, van hem blijft ver het gevaar.

1194 De zeven mannen, met als nummer acht de hond, - hier o verwanten stel ik de hen betreffende doe'a:....

Voltooid werd de schrijverij op Zaterdag, halverwege den tijd voor de verplichte middaggodsdienstoefening.

Mijn schrift deugt niet vrienden, te schrijven ben ik niet gewoon.

Op den 12-den Doelkaidah werd mijn verhaal geheel voltooid, in het jaar 1329.

$\mathrm{Nu}$ zeg ik de plaats waar ik schreef, opdat ge wete waar ik de vertelling deed. Het was te Matang Keupoela in Blang Awé. Teungkoe Ali heet de verteller.

Wilt ge (dit geschrift) voor een oogenblik (teleen) vragen, richt $U$ dan aan dat adres o broeder.

Geëindigd werd deze schrijverij tegen twaalven. Uit is ze. Amin! o Heer aller werelden, uitgezegd is het woord, Amin! 
TEKST A.

Béseumélahirahmanirahim - toedjōh bòh isim njang that meulia ébeunoe 'abaïh njang pò riwajat - djeuët keu oebat tamsé peunawa sabda nabi sòjdénkarim — toedjōh isim neujoeë adja neujoeë peuroenòë kanas ${ }^{s}-k^{\prime} a n a$ ' - nameung djaras mara baja

5 bès djeuët djipeurab iblih lasnat - deungòn beureukat nama èëlia antara 'isa deungòn moehamat - oereuëng njan meuhat sabòh masa dalam tapeusé geuriwajat - nan ngòn sipheuët geupeunjata soeratōjkapi bas djoeïh sōbeuhan - disinan tèèlan lahé njata padoem-padoem na peureuman toehan - peungadjaran keu nabi kita

10 oereuëng njan toedjōh lapan ngòn asèë — that meuteuntèë kalam rabana aseuhabōjkapi oereuëng toedjōh - baranggasòë trōh djaras ${ }^{s}$ baja sangkira tasoerat nibas roemòh - peunjakét gadòh $\mathrm{dji}^{s}$ ōh bala adat geutōt roemòh han toetōng - toehan toelōng ngòn sababnja doem pantjoeri han djeuët djikarat - sabab beureukat nama èëlia

15 ngòn raseuki keumoedahan - karōnja toehan rabōnsama sangkira tasoerat njan ba $^{s}$ bidō $\bar{s}^{s}$ - han lé doedōs barangdjan masa han lé karam dalam la $a^{s}$ ôt - beuthat ribōt njang lagòëna djaras $^{s}$ toepheuën djisōh bakat - deungòn beureukat nama èëlia hana toehan bri geutanjòë meukarat — ngòn beureukat asòë goeha

20 aneu's miët mòë njang that kajém — tasoerat isim toedjōh nama 'òh lheuëh tasoerat $\mathrm{ba}^{s}$ keureutaih - teuma takeubah ba ${ }^{s}$ teumpatnja atawa tabōh dalam bantaj - han lé sagaj djimeudjaga djimòë han lé djiséh mangat - sabab kramat nama èëlia bès han tasoerat wahé sahbat - kasiët le that toehan karōnja

25 oereuëng njang meugòë na gèt padé - tasoerat lé nama meulia tasoerat $\mathrm{ba}^{s}$ kajèë harah beukeunòng - diteungòh oemòng njan tapoela sigala peunjakét han lé keunòng - tikōïh ngòn geusòng han lé djilangga oebat moemang pi sit djeuët that — njan tasoerat beukeunòng koetika $\mathrm{ba}^{s}$ djaròë oeneun njan tas ${ }^{s}$ ikat — karōnja halarat sidjoeës angèëta

30 moemang gadòh toebōh mangat — ngòn beureukat nama èèlia oereuëng njang boenténg djeuët soekaran - tasoerat tèëlan sigra-sigra 'òh lheuëh tasoerat teuma talipat - lheuëh njan tasikat bas oeram pha $\mathrm{ba}^{s}$ pha oeneun njan tas ikat - toelōng halarat boedas keuloea boedas $^{s}$ teubiët deungòn mangat - karōnja rahmat toehan asa 35 aneus ngòn nang djeuët seulamat - deungòn beureukat nama èèlia 
sangkira tamè bas meuhoekōm - meunang hé kawōm djinòë gata beutangoej soerat hé tèëlan - keunòng atoeran narit gata $\mathrm{ba}^{\mathrm{s}}$ sapaj oeneun njan tas ${ }^{s}$ ikat - meunang meuhat $\mathrm{da}^{s}$ wa gata beutapatéh soenggōh-soenggōh - sit beutabōh bas koepala

40 sit beutangoej baranggadjan — karōnja toehan djaras baja sangkira gata radja bōh salah — keunòng amarah teumeureuka teuma 'òh tadja ${ }^{s}$ tangoej soerat - meu'ah meuhat han lé meureuka akaj peunòh sòë njang soerat - leubèh pangkat lagi ngòn kaja sangkira tabri ba' inòng madeuëng — boerōng badjeuëng han djeuët djidaja

45 han djeuët lé djidjas ōmi sébeujan - meuteumèë meunan dalam sabda ōmi sébeujan inòng tjèëtan - djidaja énsan boeda ${ }^{s}$ keuloea meung na soerat djaras ${ }^{\mathrm{dji}}$ that - deungòn beureukat nama meulia $\mathrm{pa}^{s}$ idah le that han és peugah - malingkan alah njang $\mathrm{e}^{s}$ hingga djeuëb-djeuëb roemòh beuna tatrōh — soepaja djisōh mara baja

50 wahé kawōm tatrōh soerat njòë — adoeën adòë doem beurata adat han djeuët tasoerat keudròë - $\operatorname{ta}^{5}$ oepah adòë tabri blandja ka han djeuët dròë gòb ta soepah - blandja tabōh doem sikada bès keu tatjhén oepah tabri - meung han pakri meuteumèë laba deungòn sabab tatrōh soerat - neubri beureukat ba ${ }^{s}$ areuta

55 ngòn raseuki keumoedahan - sabab tèelan nama meulia raseuki moedah baja gadòh — sòë njang na trōh nama èëlia beureukat kramat isim njang toedjōh - toehan peutrōïh ban njang sabda sōbeuhanalah wabihamdihi - meuha soetji alah ta'ala gadòh bantji teuka gaséh - meung tapatéh kalam rabana

60 sōbeuhanalah waleuhamdoelélah — njòë lōn kisah nama èëlia toehan toelōng nibas malang — djinòë lōn karang seun sibandja lōn toeëng beureukat nibas goerèë — lōn toeëng teuradjèë ba ${ }^{s}$ oelama oelōn peusatjèh djoeïh sōbeuhan - toelōng toehan beus és $^{s}$ leungka soepaja moephōm ba $^{s}$ oereuëng doengèë — njang na èleumèë doem sikada

65 deungòn mòsdjidat sigala nabi — beu toehan bri iman sampōreuna kalam toehan beus $\mathrm{e}^{s}$ lōn seusōn — hingga adjaj lōn hilang njawa deungòn beureukat kalamoelah - la élaha élalah beus és $^{s}$ lon kata watèë soekreuët neubri seulamat — sòë njang ingat kalimah meulia deungòn beureukat ajat koeroesan — peureuman toehan njang meulia

70 peureuman alah dalam koeroes an - doemteu tèëlan bès taloepa Kala'llahoe Ta'ala: Am hasibta anna ashāba'l-kahfi wa'r-raḳini kānoe min ājātinā 'adjaba neuleungò nibas 'òjnòn na'im - $\mathrm{ma}^{s}$ na rakim njang tjalitra lhèë dròë oereuëng wèh di gampōng - djas lam goenòng meudiwana teukeudirōlah meuleuha koedrat — njeum rōt langèt ateuëh koepala

Deel 98. 
ban djikalòn laloe djiploeëng - seun-sreut meuteumeung sabòh goeha

75 goeha batèe sangat indah - djitamòng pantaïh sigra-sigra 'òh saré trōih djih oedalam — rōt lé meugam pintō goeha goeha teutōb njan ngòn batèë — pakri lagèë lheuëh oeloea laloe djimarit sabé keudròë — pakri geutanjòë teubiët oeloea baranggakri han és tasilah - meung kòn $\mathrm{ba}^{s}$ alah tamoepinta

80 peuë na 'amaj toehan trimòng - djinòë tatoeëng sinan pahla talakèë bas alah doemteu djinòe — beuleupaïh geutanjòë nibas goeha

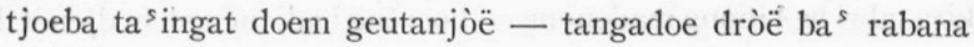
kri tjit narit teuma njang sidròë — geuhareutòë ba ${ }^{s}$ njang doea tangò adòë lōn hareutòë — masa sabòh ròë lōn keureudja

85 niba $^{\text {s }}$ peunjeum lōn mòseutadjabah - djinòë lōn peugah ba $^{s}$ rabana lōn peus'oepah gòb poeboeët 'amaj — lōn bri pangkaj ngòn blandja ban njang mas loem lōn bri meuhat - oelōn peusadat barangdjan masa $\mathrm{ba}^{s} \mathrm{si}^{s}$ oeròë oepah ka meuhat - meunan adat lōn keureudja nibas si soeròë toehan teukeudi — sidròë paki njan djiteuka

90 roepa pi gèt salèh han sòë - oereuëng lakòë that takoea oelōnteu peudòng lōn joeë ibadat - oepah meuhat oelōnteu peuna oelōnteu kheun $\mathrm{ba}^{s}$ oereuëng njan — tadòng kaman sinòë gata ta sibadat sikhan oeròë — oepah doemnòë koebri keu gata sadoem ngòn oepah njang si soeròë — tadòng sinòë moeda balia

95 lheuëh njan djidòng sikhan oeròë - toehan djipoedjòë hana reuda 'òh trōih $\mathrm{ba}^{s}$ hat sikhan oeròë — djilakèë dròë njan djigisa lōn bri oepah ban njang djandji — laloe paki ka djiboengka oereuëng njang dilèë teuma soedi — padoemna tabri keu moeda balia teuma lōn peugah ban njang lōn bri — beungèh paki njang peutama

100 oelōn njang poeboeët si ${ }^{s}$ oeròë soentō ${ }^{s}-$ sadoem tjit tadjōo lagòë blandja jōh njan ka beungèh boekòn boebarang - paki djiriwang ka djiboengka tinggaj oepah djih djibòih dròë - oelōnteu doedòë soesah raja oepah njang tinggaj leumò lōn blòë — oeseuha dròë oelōn plara djimeusaneus hana teudōh — hingga trōïh plōh peunòh blang raja

105 padoem lawét akhé doedòë — oereuëng sabòh ròë lòm ka teuka oemoe toeha sangat la'èh - thatkeu leumòh djeuëb angèëta laloe djingadab $\mathrm{ba}^{s}$ lōn sidròë — oepah sabòh ròë njan djipinta leumò pi le djeuët bas oelōn — ka trōih roekōn bas lōn kira oelōn peudjōs teuma oepah - leumò bahrōlah milés gata

110 teuma djikheun lōn poewajang - hana sajang lōn ka toeha oelōn meusoempah walah bélah - sabét njò sah milés gata lōn peugah haj keulakoean - di asaj phồn lōn tjalitra teuma djipoewòè leumò habéh — sit lōn gaséh até soeka 
njankeu 'amaj lōn hé tèèlan — niba s toehan lōn toeëng pahla

115 ja toehankoe taleungò kamòë — lōn poeboeët njòë keureuna gata

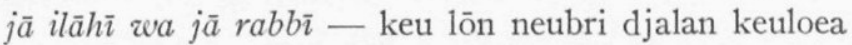
meungnjò ékeulaih 'amaj lōn njòë — beuleupaïh djinòë nibas goeha kalam pi rōt njan di babah — goenòng pi tjrah peungeuïh teuka barō leumah tjahja oeròë — djijoeë lòm doedòë bas tèëlannja

120 tjoeba digata meuhòn $\mathrm{ba}^{s}$ alah — kadang mèë teuhah pintō goeha teuma meutoetō sidròë tèëlan — di lōn pi rakan bah lōn tjoeba di lōn pi na sabòh 'amaj - peureuboeëtan oentōng moeda $\mathrm{ba}^{s}$ sabòh masa jōh sabòh ròë — deuës that nanggròë makanan hana makanan le ba ${ }^{s}$ lōn sidròë - lasén sinaròë han sapeuë na

125 inòng dara teuka ba ${ }^{s}$ kamòë — ngòn sambinòë djròh that roepa roepa that djròh hana lawan — tamsé intan djiploeëng tjahja djidjas gadè ba ${ }^{s}$ lōn makanan - jōh masa njan peuë halé na djilakèë makanan bas lōn sidròë — dara sambinòë djròh that roepa peuë na makanan teungkoe djinòë - oelōnteu njòë lapa dahga

130 adat na makanan neubri djinòë — deuë ${ }^{s}$ oeròë njòè hana tara soeara mangat han treu peugah - roepa indah sang meutia roepa sambinòë djròh that lakoe - oelōn nabsoe teuka hawa teuma lōn kheun $\mathrm{ba}^{s}$ oereuëng binòë — oelōnteu njòë nabsoe keu gata taleungò oelōn pò sambinòë - oelōnteu njòë teuka hawa

135 njang keu gata até lōn that - peuë njang hadjat oelōn peuna meung tapeutrōih hawa lōn njòë - barangpeuë djinòë lōn bri keu gata dami djileungò lōn kheun lakoe - neuprèh teungkoe sikléb mata lōn dja' tanjòng bas soeami - meungka neubri oelōnteu teuka oereuëng binòë djiwòë ninan — djidjas ${ }^{s}$ kheun jōh njan bas djoedōnja

140 'oh saré trōih ba $^{s}$ soeami - djitanjòng kri pantaïh sigra habéh djipeugah gòb meukeusoet -lakòë djiseus ōt peuë salah na ka djilakèë djas lèh tabri - moebès maté aneu ${ }^{s}$ tjoet raja lheuëh njan djidjas oereuëng binòë — djandji boenòë ka djirila teuma lōn kheun $b^{s}$ oereuëng binòë - tasés keunòë sigra-sigra

145 'oh saré trōïh djis $^{s} \mathrm{e}^{s}$ bas oelōn — ladjoe djilhōn leumah angèëta djitoempōs idja leumah "èërat - lōn makén that teuka hawa 'òh saré rab oelōn keunan - jò djih jōh njan misé geumpa teuma lōn kheun $\mathrm{ba}^{s}$ oereuëng binòë - pakòn meunòè jò angèëta oereuëng binòë teuma seu ${ }^{s}$ òt - sabab lōn takōt keu rabana

150 ngòn leumbang-leumbōt njan djiseu ${ }^{s}$ ōt - djikheun djitakōt keu hakoe ta'ala sabab lōn takōt njan keu toehan - leungò badan jò angèëta dami lōn leungò meunan djipeugah — di lōn pi soesah até lam dada leumòh ngòn toebōh teumakōt até - lōn tanjòng lé pantaīh sigra 
pakri tatakōt njan keu toehan - lōn soekaran hana tara

155 oereuëng binòë lòm djiseus̄ōt - leumah-leumbōt deungòn soeara alah hé teungkoe lōn takōt that - sés sa sangat lam noeraka njankeu sabab leungò badan - lōn takōt keu toehan teumeureuka peuë djeuët mangat teungkoe djinòë — pagé doedòë keunòng sés sa teuma lōn kheun $\mathrm{ba}^{5}$ inòng njan — bit kòng iman that di gata

160 lheuëh lōn kheun njan teuma doedòë - lōn pi han sòë teumakōt raja oelōn takōt keu pòteu alah - teuka goendah até lam dada lōn tōb 'èërat boeët han djadèh — teuma lōn wèh pantaïh sigra boeët han djadèh lōn tōb 'èërat — lheuëh njan lōn tèëbat ngòn nasoeha oelōn tèëbat lōn bri kiparat - keureuna 'èërat ka teuboeka

165 lōn bri seudeukah keu oereuëng binòë — djitrōn djiwòë bas ${ }^{s}$ djoedōnja njankeu 'amaj ka lōn peugah - meung njò ékeulaïh beuleumah tanda ja toehankoe taleungò kamòë - lōn poeboeët njòë keureuna gata djakalèë neutoeëng 'amaj lōn njòë — beuleupaih djinòë meuteubiët oeloea djikheun pi lheuëh goenòng pi teuhah - deuilh lé leumah njan oeloea

170 kakeu leumah mata oeròë - peungeuïh sampòë ban sabòh goeha dji seu oeloea leumah doempeuë — peungeuih meusimpreuë sigala dōnja han tjit na djeuët lòm djiteubiët - mantòng meugriët dalam goeha teuma meutoetō sidròë tèëlan — njankeu rakan njang keutiga di lōn pi na jōh sabòh ròë - bakeuti lōn sidròë keu iboe bapa

175 ma lōn ngòn koe toehaneu that — lōn hareukat mita blandja lōn toeëng oepah goebeuë kamèng - keu napakah iboe ngòn bapa geunab beungòh lōn prah ië abin - keu minòman dròëneu doea beungòh seupōt poewòe ië abin — that bit jakin keu nang apa $\mathrm{ba}^{5} \mathrm{si}^{\text {s } o e r o ̀ e ̈ ~ t e u k e u d i r o ̄ l a h ~-~ o e d j e u e ̈ n ~ d j o ̄ h d j a h ~ t r o ̄ i ̈ h ~ n g o ̀ n ~ s i n d j a ~}$

180 oeròë pi seupōt oelōnteu wòë — ajah doea dròë teungeut indra ngòn ië abin lōn mat di djaròë — ajah doedòë lōn prèh djaga simalam soentōos lōn dòng sidròè — ajah lōn sidròë hana djaga phōn sindja kòn hingga soebòh - hana sabòh pi na djaga até lōn goendah boekòn boebarang - mangkōng lōn tatang trōïh 'òh padja

185 lōn dòng sidròë dalam seupōt - até teumakōt salèh meureuka awaj soebòh teukeudi toehan - djaga jōh njan oereuëng doea neubeudòih ajah neukalòn oelōn - lōn $\mathrm{djo}^{s}$ mangkōng pantaïh sigra $\mathrm{ba}^{s}$ neusangka oelōn ban trōîh — neutjòs ${ }^{s}$ mangkōng neutrōn landja neutrōh ië abin jōh njan reudjang — neudjas seumajang poedjòë rabana

190 lōn pi lōn trōn jōh njan sadjan — djas toeëng ië seumajang ngòn ajaheunda ajah boenda oelōnteu sidròë - malam oeròë poedjòë rabana 'òh lheuëh seumajang baranggadjan - djas toeëng oepahan $\mathrm{ba}^{\mathrm{s}}$ oereuëng kaja 
oelōn plara oereuëng doea dròë - han lheuëng oeròë mita blandja ranoeb pineung boe ngòn eungkōt - beungòh seupōt lōn dja $^{s}$ mita

195 lōn blòë idja deungòn badjèë - na bès malèë ba ${ }^{s}$ oereuëng lingka jōh masa njan lōn that djeumòt — sira ngòn panjòt lōn djas mita lōn toeëng oepah goebeuë kamèng — djeuëb-djeuëb gampōng meureuraba 'òh trōih watèë lōn seumajang — reudjang-reudjang poedjòë rabana keureuna oelōn peudéh oentōng — pat meuteumeung oereuëng kaja

200 lōn beudòih ninan dja $^{s}$ goebeuë kamèng — 'òh lheuëh njan saweuë ajaheunda tinggaj rahmat teuma doedòë — wòë oe nanggròë keukaj baka 'òh lheuëh lōn tanòm ban doea dròë - teutab lōn njòè han lé gōga meunankeu boeët di lōn sidròë — masa jōh ròë oentōng moeda njankeu 'amaj di lōn sidròë — beuleupaïh djinòë teubiët oeloea

205 ja toehankoe tadeungò kamòë — lōn poeboeët njòë keureuna gata meunjò ékeulaïh 'amaj lōn njòë - beuleupaïh djinòë ja rabana kalam pi lheuëh goenòng pi teuhah - jōh njan leupaïh teubiët oeloea teukeudirōlah meuleuha koedrat - ban thèe meuhat theuëh oeloea jōh njan ka teuteubiët oereuëng lhèë dròë — meunan adòë sabòh tjalitra

210 meunankeu doem maséng riwajat - deungò sahbat doem beurata masna rakim neukheun lòh batèë - meunan meuteumèë sabòh tjalitra aseuhabōjkapi sinan meusoerat - geutrōh meuhat di pintō goeha lòh njan geubōh dalam peutòë - meunan adòë sabòh tjalitra sōbeuhan alah pò lōn rabi - aseuhabōjkapi lōn tjalitra

215 antara 'isa ngòn moehamat - meunan sahbat dalam sabda aseuhabōjtèërit njang riwajat — teuleungò bas sòjdina 'oema $\mathrm{ba}^{s} \mathrm{si}^{s}$ oeròë toehan teukeudi - lhèë dròè jahoedi keunan teuka lhèë dròë jahoedi teuka keunan - meutoetō jōh njan sidròë panita ngòn toeanteu 'oema jahoedi marit - djitanjòng keubit djiparés sa

220 jahoedi djidòng dihadapan — djitanjòng jōh njan pantaïh sigra hé ja 'oema di likōt moehamat — peutimang ras jat mat neuratja gata radja $b^{s}$ masa njòë - peutimang nanggròë peukòng agama djinòë koetanjòng doem masasalah — beutapeugah hé ja 'oema meung djeuët tapeugah masa ${ }^{s}$ alah njòe - reumbang $b^{s}$

kamòë agama gata

225 njò moehamat sibeuna nabi — hana meudeungki kamòë doemna meung han djeuët tapeugah masa ${ }^{5}$ alah njòë — kòn ba $^{5}$ kamòë agama gata nabi moehamat boekòn rasoej - njò barangpeuë tipèë daja sòjdina 'oema neuleungò meunan — neudjaweuëb jōh njan pantaïh sigra tatjoeba tanjòng hé jahoedi - toelōng rabi akan hamba

230 laloe djitanjòng oelé jahoedi - langèt peuë goentji ngòn geuboẹka 
koeboe njang djas ngòn asòë-asòë — njang peusingat kawöm dròë kòn manoesia

kòn djinèh djén wahé sòjdi — beurapa lagi masasalahnja limòng peukara djinòë lōn tanjòng - peugah beukeunòng bès meuriba njang limòng njan tapeugah ma wang — hana djikandōng lé iboe bapa

235 manò $^{s}$ koekoeës $^{s}$ peuë djipeugah - takheun beusah tapeunjata di tjanggoeës ${ }^{s}$ peuë djikheun djinòë — di mirahpati peuë djikata bahkeu doemnan dilèë $\mathrm{si}^{s}$ at - tjoeba tasingat oebé njang ka sòjdina 'oema toendōs oelèë — meunjeum malèë bas panita neutoendōs oelèë njan oe boemòë - seureuta neumòë trō ië mata

240 han djeuët neupeugah tanjòng jahoedi - hana toehan bri èleumèë lam dada laloe djibeudòih panita jahoedi — ngòn djikheun kri pantaïh sigra nabi moehamat njò kòn nabi - djinòë meudeungki kamòë doemna agama éseulam njö bit bateuë — njò barangpeuë tipèë daja

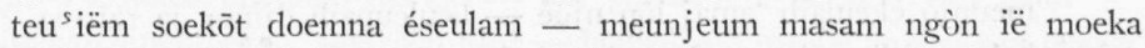

245 panita jahoedi makén girang — soelòjman grantang pantaïh sigra na sikeudjab jahoedi girang - meugrantang ngòn soeara njan geupeunan soelòjman parisi — hé jahoedi taleungò hamba piōh si'sat hé jahoedi — sòjdina 'ali djéh ka teuka dami leumah sòjdina 'ali — teusiëm jahoedi sikoetika

250 sòjdina 'ali peutrōih keunan — 'oema jōh njan até soeka jōh njan beudòih neudjas mat djaròë — sira neumòë trō ië mata moemat djaròë ban njang adat — até mangat sòjdina 'oema lheuëh njan teuma nakeu $\mathrm{si}^{\text {s }}$ at - soelòmman itjarat djaweuëb sigra peuë djih djitanjòng oelé jahoedi — soelòjman parisi neutjalitra

255 na sikeudjab theuëh nibas njan — 'ali jōh njan laloe beureukata hé jahoedi djinòë kapeugah — peuë masasalah tanjòng gata djinòë tatanjòng hé jahoedi — djaweuëb lōn bri tanjòng gata rasoelōlah neupoebeuët oelōn - èleumèë meuhimpōn didalam dada meuribèë pintō nibas èleumèë - alah bri thèë akan hamba

260 éntja alah tatjoeba tanjòng - beukeunòng-keunòng soe ${ }^{s}$ euë gata teutapi na hadjat kamòë — taleungò djinòë hé panita

- meunjò tatém masōs ${ }^{s}$ éseulam - djinòë lōn bri pham njang sidjahtra meutatém oetjab doea kalimah — djinòë lōn peugah tanjòng gata meutatém poeboeët ban di kamòë - lōn djaweuëb djinòë tanjòng gata

265 djinòè lōn djaweuëb dalam tèrit - ban njang narit nabi 'isa djaweuëb jahoedi djikheun na'am - sòjdi lanam njò sibeuna njò moehamat sibeuna nabi — han meudeungki kamòë doemna oelōnteu tém masō’ éseulam - oelōnteu pham ban di gata oelōnteu tamòng agama moehamat - beule rahmat keu kamòë doemna 
270 lheuëh njan djitanjòng oelé jahoedi - nibas 'ali djiparés sa sòjdina 'ali toendōs oelèë — neungò̀ lagèë tanjòng panita phōn djitanjòng lé jahoedi — sòjdina 'ali neungò njata pintō langèt peuë keu goentji — wahé 'ali peuë ngòn geủboeka moetjrés bélah djaweuëb 'ali - njankeu goentji las én hana

275 oereuëng moetjrés 'amaj dji tan — neutōb lé toehan pintō doemna aneu $^{s}$ goentji tas oetjab tjahđat - langèt meuhat pintō teuboeka pintō langèt toedjōh lapéh — bandoem habéh pintō teuboeka kaphé moetjrés meugoentji meuhat - ta soetjab tjahdat mangat geuboeka lòm meutoetō sòjdina 'ali — hé jahoedi tanjòng landja

280 lòm djitanjòngng oelé jahoedi — oeba ${ }^{s}$ 'ali djiparés sa koeboe djidja ${ }^{5}$ asòë didalam — djinòë tabri pham keu kamòè doemna djaweuëb 'ali tanjòng jahoedi - neupeugah kri pantaïh sigra koeboe njang dja $^{s}$ asòë didalam — djinòë tapham hé panita njankeu eungkōt njang 'oeët nabi nòh — djimè ban sabòh oe la ${ }^{s}$ ōt raja 285 njankeu koeboe djidjas $^{5}$ ngòn asòë-asòë — njang la ${ }^{s}$ én sinaròë meunan hana

lòm djitanjòng lé jahoedi - oebas 'ali djiparés sa na sapeuë treus wahé kawōm - deungò bandoem tjoeba peunjata geukheun kòn djén boekòn énsan - salèh peuë nan ja sòjdina djaweuëb 'ali jōh masa njan - neupeugah nan nibas panita

290 njankeu sidòm nabi soelòjman - ba $^{5}$ ri toerōn nan hé panita lòm djitanjòng oelé jahoedi - oeba ${ }^{s}$ 'ali djiparés sa limòng peukara djinòë koetanjòng - hana djikandōng oelé boenda salèh peuë nan njan geurasi - hé ja 'ali tjoeba peunjata djaweuëb 'ali jōh masa njan - neupeugah nan limòng peukara

295 nama njang phōn nabi adam - njankeu tapham njang peutama keudoea oenta nabi salèh - keulhèè kibaïh ébeurahima keupeuët sidòm nabi soelòjman — binatang njan asòë tjeuroega njang limòng njan tadeungò djinòë — nini geutanjòë toeanteu hawa teuma djitanjòng lé jahoedi - hé ja "ali neupeugah landja

300 manò $^{s}$ koekoeës oeròë ngòn malam - njan tabri pham keu kamòë doemna peuë djipeugah njan djikoekoeës - that bit koetjhoeës ta $^{s}$ eu roepa djitangah oe langèt djiteukoeë oe boemòë — sang djimòë trō ië mata oelèë meusanggo ${ }^{s}$ gèt that lagèë - peuë djibri thèë manòs beureukata djikeupa $^{s}$ sajeuëb djisanggōo ${ }^{s}$ oelèë - gèt that lagèë ta ${ }^{s}$ eu roepa

305 djitangah djiteukoeë peuë djikheun - pleuheuën-pleuheuën njan djikata leumbang-leumbōt soeara pleuheuën-pleuheuën - that bit hireuën ta ${ }^{\text {seu }}$ roepa

djipeugah peuë oeròë ngòn malam — djinòë tabri pham ja sòj̣ịnạ 
djaweuëb 'ali tanjòng jahoedi - neupeugah kri manò ${ }^{s}$ beureukata djikeupa $^{\text {s }}$ sajeuëb djiroekoes soedjoet - toehan mas boet han djiloepa

310 djikeupa $^{s}$ sajeuëb jōh masa njan - djipoedjòë toehan rabōnsama djikeupa $^{s}$ sajeuëb djis anggōo $^{s}$ oelèë — sit djibri thèë keu manoesia seureuta djikheun oedkoer allāh min al-gāfilīn - wahé mòs min bès

that loepa

djijoeë ingat keu pòteu alah - bè' that dasah ingat keu donja njankeu djikheun manòs koekoeës $^{s}$ - takalòn koetjhoeës jōh djikata

315 djipeu $^{s}$ ingat oereuëng njang lalòe — han thèë keudròë ateuëh dōnja han thèë keudròë peuneudjeuët toehan — pagé tèëlan masōs noeraka manòs $^{s}$ koekoeës njan djipeugah - tapham beusah hé panita lòm djitanjòng lé jahoedi - oebas 'ali djijoeë tjalitra soeara goeda tadeungò meuhihi - djinòë neukheun kri peuë djikata

320 djaweuëb 'ali tanjòng jahoedi - goeda meuhihi neupeugah ma ${ }^{5}$ na tadeungò koepeugah hé jahoedi — goeda meuhihi njòë djikata allāhoemmā anșoer 'íbādanā moe minīn 'alaika fārrīn - doe'a keu mòsmin djilakèë lé goeda boemeunang mòs min beutalō kaphé - meunan sabé djikheun lé goeda neupeugah pi lheuëh oelé 'ali — panita jahoedi tanjòng landja

325 di mirahpati peuë djipeugah - hireuën dasah koedeungò soeara sang-sang djikheun keubroebroe - meunan lakoe boenjòë soeara 'ali deungò djitanjòng meunan - neupeugah jōh njan pantaïh sigra di mirahpati djikheun jahoe - djikheun teungkoe alim oelama djiseurapa njang toeëng adat glé — njang toeëng wasé adat koeala

330 djiseurapa geunab oeròë — riōh boenjòë geunab masa hana teudōh njan di babah - allāhoemmā al'oen al-'asjarah njan djikata ja toehankoe tabri lasnat - keu oereuëng toeëng adat koeala njankeu djikheun di mirahpati - hé jahoedi pham lé gata jahoedi tanjòng hana teudoeë ${ }^{s}$ - soeara tjanggoeë ${ }^{s}$ peuë djikata

335 tjanggoeës peuë djikheun riōh sabé - neupeugah lé ja sòjdina djaweuëb 'ali hana teudoeës - soeara tjanggoeës neutjalitra njang soe tjanggoeës oetjab teuseubèh - lapaj sarèh poedjòë rabana hana lalòe teuseubèh djiseuboet - soebhāna rabbíl-ma'boed njan

djikata

djis oetjab teuseubèh hana khali - djipoedjòë rabi toehan asa

340 soelöih njang akhé doem djibeudòih - hana sabòh njang han djaga seureuta djis oetjab sōbeuhan rabōnmas boet - di toehan djiseuboet rata-rata

jahoedi deungò djaweuëb 'ali - djis ${ }^{s}$ otjab lé kalimah doea kalimah djis oetjab até mangat - éleuham halarat dalam dada 
asjhadoe alla ilaha illa'lloh wa asjhadoe amna mochammadan 'abdoehoe swa vasocloeloe - jahoedi soenggōh masōs agama

345 njang doea treu ${ }^{5}$ disinan tècelan - djimeus ${ }^{s}$ iman sadjan panita habêh ban thèe masō ${ }^{*}$ èseulam - trōn éleuham dalam dada teuma doedòe sabòh treus kawōm - ban sabòh bhōm roekōn panita njang na rōh bhöm bandoem keu bië ${ }^{s}$ - habéh masōo ba agama bandoem djitamòng agama éseulam - trōn éleuham ba ${ }^{5}$ alah táa ala

350 teumanjòng lòm panita jahoedi - oeba $^{s}$ 'ali djiparés sa djitanjòng èleumèèji hana tón $\bar{o}^{s}$ - òh theuëh djimaso ${ }^{s} \mathrm{ba}^{s}$ agama jōh njan djitanjòng reudjang pantaïh — na masa ${ }^{5}$ alah njang gòh lōn boeka njòè na sabòh masa'alah — djinòè tapeugah ja sòjdina djaweuëb 'ali reudjang pantaih — tanjòng bethabéh oelé gata 355 toelōng alah mòs djidat nabi - djaweuëb lōn bri tanjòng gata jahoedi deungò toetō 'ali - djitanjòng lé pantaïh sigra oereuëng djameun geukheun toedjōh dròë — han lōn toesòë geukheun nama Ihèëreutöihsikoereuëng thōn lheuëh maté - teuma oedéb lé misé njang ka nanggròëgeu pat namageu sòë — oereuëng toedjôh dròë maté lam goeha

360 asèe sabòh geukheun sadjan - ngòn njan lapan geudjas tapa oereuëng toedjōh dròë lapan ngòn asèë - sit meuteuntèë geudja ${ }^{s}$ tapa geudjas tapa dalam goenòng - teuma geutamòng dalam goeha peuë nan goeha peuë nan goenòng - njan lōn tanjòng oeba ${ }^{s}$ gata sit njan keu toean tanjòng kamòë - tapeugah djinòë ja sòjdina

365 sòjdina 'ali lheuëh neupiké - neudjaweuëb lé tanjòng panita jōh njan neudjaweuëb oelé 'ali — sabda nabi neutjalitra na teuseuboet dalam koeroes an - sipheuët gòb njan ban sineuna aseuhabōjkapi ban toedjōh dròë — di roem nanggròë teumpat ajaheunda mideuën akeusoeih nan bariah - djahéliah njang bōh nama

370 oereuëng éseulam nama teusoerat - meunan teuseuboet dalam tjalitra silajeuë keuradjeuën malés salèh - além pi leubèh lagi war‘a 'òh lheuëh maté njan teuma doedòë — la én meugantòë njang beuragama keuradjeuën kianòih teuma doedòe — radja pindòë tan agama kianòih njan radja parisi - djimeus oengki keu agama

375 djigoebeuë kamèng djihnjan dilèë — hana sòë thèë djeuët keu radja teukeudirōlah meuleuha koedrat - meuteumèë teumpat kajèë raja dijoeb kajèë njan sinan djipiōh - kamèng peutrōih keunan teuka na sikeudjab kianòih piōh - kamèng pi trōïh sangat dahga djikoerès tanòh ië djimeung bri — toehan teukeudi lagi mata 
380 djikoerè ${ }^{s}$ tanòh jōh masa njan - leumah disinan peutòë raja 'òh ban djis'eu leumah peutòë —- đjipeurab djaròë ka djiboeka teuma djikalòn keureutaïh djròh-djròh — kianòih plòih jōh njan sigra meusoerat didalam misé kitab - kheuët pi djròh that hana tara kianòih mè oe beunasah - ba $^{5}$ toean siah djijoeë batja

385 tjoeba teungkoe beuët soerat njòë — koeteumèë boenòë lam peutòë raja lam peutòë boenòë koeteumèë - dijoeb kajèë koekoeëh teulaga lōn koerè ${ }^{s}$ tanòh $b a^{s}$ bri ië kamèng — seun-sreut meuteumeung peutòë raja ië kamèng pi han meuteumèë bri - ladjoe peureugi keunòë bas gata le that teungkoe soerat didalam - han djeuët lōn pham poeëh that basa 390 peunòh peutòë soerat didalam - han djeuët lōn pham la én basa njankeu teungkoe lōn mè keunòë - neubeuët djinòë peuë na haba kianòih $\mathrm{djo}^{s}$ soerat keunan — teungkoe tjhèh njan djeuët neubatja siah njan toeha oemoe ka djameun - silajeuë keuradjeuën nabi moesa soerat neubeuët basa dilèë — tjhèh njan geuthèë oemoe ka lama

395 haba lam soerat that djilakab - basa kitab nabi moesa siah neubeuët soerat $b^{5}{ }^{5}$ djaròë — radja karōn njòë njang pò areuta haba lam soerat habéh moephōm - doeablaïh geudōng meuïh lingkanja masa radja boemòë peureulan - ngòn meuïh sadjan djíoeët landja masa karōn dji'oeët lé boemòë — seurapa sidròë nabi moesa

400 nabi moesa joeë bōh djakeuët - bè ${ }^{s}$ djireubōt alah táala han djisikōt nabi peugah — nabi djitoekaïh djikheun meudina njankeu sabab radja karōn — boemòë peureulan oejoeb dōnja doeablaïh mòn peunòh limpah — tjhèh njan peugah neutjalitra tjhèh njan peugah ba ${ }^{s}$ kianòih — meuïh that damòh djeuëb-djeuëb teulaga

405 kianòih tanjòng djinòë pat teumpat — na koedjas koeëh tatoeëng doea teungkoe tjhèh njan peugah teumpat - kianòih meutat-tat até lam dada njeum beuhabéh tatoeëng sidròë - jò ngòn asòë misé geumpa kianòïh wòë lé oeroemòh — djihej mèhmòh éseutirinja tasoerōng lham keunòë reudjang — koemeung mè oe blang dja, koeëh teulaga

410 hana pat lé bri ië kamèng - tamè reudjang oeròë ka sindja oereuëng binòe teuma seusōt- pakòn 'òh seupōt neukoeëh teulaga adat malam pi leumah deuih - boeleuën peungeuih peuë goendah gata oereuëng binòe teuma soerōng lham - kianòih oe blang djidjas landja watèë moegréb rab trōih 'itjha - kianòìh landja njan djisapa

415 na sikhan rèt kianòih $\mathrm{dja}^{s}$ - seun sreut meuroempa ${ }^{s}$ iblih tjilaka teudòng di rèt misé siah — hana oebah sang oelama kianòih kalòn jōh njan that deuih - oereuëng keumiët meuïh ban djisangka kianòih eu hana oebah — moebadjèë djoebah sang oelama 
iblih las nat joeë dòng kianòih - bès that mèhmòh tadjas gata

420 hé kianòih kadòng dilèë - kaleungò kèë sabòh bitjara kadjas riwang dilèë pantaïh - kapòh siah njan boepahna kapòh siah djéh boematé - meuih njan bès lé kaweuës doea meuih na habéh katoeëng keukah - djas lèh pantaih $\mathrm{ka}^{s}$ inanja ban djileungò iblih peugah - doem geukeubah didalam dada

425 gòtkeu koepòh siah dilèë - koetoeëng keu kèë meuïh doem njang na kianòih riwang oe beunasah - teungkoe siah djidjas mita landja djis $\mathrm{e}^{s}$ oe beunasah — peudeuëng pantaïh djisoeët sigra djikeumeung tjang teungkoe siah — neukheun pantaïh meunòë haba hé kianòih bès pòh oelōn - meuïh sikeulian han lōn hawa

430 kianòih kheun peuë tapeugah - meung kèë koedjas ${ }^{s}$ koeëh hana hawa 'òh koedjas koeëh bas malam njòë - singòh oeròë kabōh da ${ }^{s}$ wa kianòih beungèh moeka mirah — djitòb siah maté pahna kianòih tòb ba $^{s}$ oelèë até - siah maté ilang njawa keunòng koetika rōh that watèë — han sabòh thèë manoesia

435 siah djitòb han sabòh thèë — reumbang watèë djròh koetika akhé djameun teuma meugah — kianòih dasah ka djeuët keu radja han hasé lé doedòë meugah - kianòih limpah keuradjeuën raja maté siah bas $^{s}$ malam njan — djikoeëh jōh njan meuih doem njang na $\operatorname{djidjō}^{s}$ keu radja meuïh nam geudōng - beuna bès maté geupòh keu bila

440 djidjo $^{s}$ keumaih ban njang nabsoe - hingga meutjeuhoe tō $\overline{b a}^{s}$ radja teuma geubri mideuën kianòih - teumpat ma ${ }^{s}$ rōh meuneu'èn radja jōh njan kianòih kaja limpah - meuïh bahrōlah djibri doemna disinan ka teutab keudiaman — kianòih jōh njan kaja raja areutadji le $\mathrm{ra}^{\mathrm{s}}$ jat meukatòë - djiprang nanggròe hana reuda

445 seun sigampōng seun sinanggròë — teuma doedòe djiprang radja 'òh habéh talō nanggròë djiprang - doedòë djiriwang djiprang radja radja pi talō nanggròë pi djitoeëng — habéh djiboeloeëng doem rata teutab djitoeëng keudjih nanggròë - djipeugòt meuligòë sabòh njang raja djipeugòt meuih piras ${ }^{s}$ beureus ${ }^{s}$ oepam - loeaih didalam siteuntang mata

450 loeaih didalam sabòh peureusah - meunan peuneugah dalam tjalitra meuligòë njan that bit indah - meuih meutatah moepeureumata ban siseun lingka djibōh keu kisiëng - hana bandéng indah roepa djipeudoeës $^{s}$ di ateuëh prataih meuih - tjahja peungeuih sigala dōnja minjeu $^{s}$ dòjtoen djipasòe didalam - geunab malam peungeuih lingka

455 meunankeu boeët radja kianòih - meuïh that damòh ladjoe teuka deureuham djipeugòt siplōh maïh brat — meunankeu boeët silajeuë djiradja deureuham njang dilèè habéh djibòih — han lé meung sabòh djeuëb-djeuëb banda 
radja kianòih meuïhdji le that - loerōng halarat ateuëh dōnja minjeus dòjtoen djipasòë lam kandé — radja djahé bòïh areuta

460 dalam meuligòë keuta sabòh - meutatah djròh lalòë mata boedjce linteuëng lapanplōh haih - meuih meutatah moepeureumata di wië oeneun kroesi meuih — djijoeë doeës di ateuëh njang

moeda-moeda

djijoeë doeë ${ }^{s}$ aneu ${ }^{s}$ oelèëbalang — sadjan déndajang djròh-djròh roepa oelèëbalang wadi meuntròë — doem sinaròë sadjan radja

465 bandoem di oelèe koelahkama meuï — tjahja peungeuïh hana tara koelahkama meuih ban peuët sagòë - ban mata oeròë limpah tjahja na limòngplōh aneus miët sinan - djròh lakoean ilōs roepa

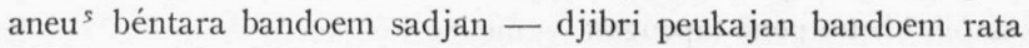
djibri peukajan idjō biroe - djròh that lakoe indah roepa

470 peukajan idjō koenèng mirah — hireuën dasah pandang roepa wareuna peukajan le that bagòe - toengkat di djaròë moepeureumata niba ${ }^{s}$ toengkat meuïh sinaròë - intan poedòë djampoe meutia na limòngplōh aneus miët njan - nam dròë disinan aneu ${ }^{s}$ oelama njang nam dròë njan djibōh keu wadi - habéh djipiké si tjilaka

475 djibōh keu wadi aneus miët nam dròë — radja pindòë la ${ }^{5}$ én bitjara habéh piké deungòn khimat - kaphé la ${ }^{5}$ nat sabòh masa hadjat djijoeë kheun dròëdji toehan - kianòïh njan asòë noeraka meuka djikheun lé aneus miët nam dròë - lasén sinaròë

meunan djipiké dalam até - teutapi tjré aneus ${ }^{s_{1}}$ oelama reudjang seureuta

480 aneus miët nam dròë doem djibòïh dròë — radja pindòë balés agama meunan piké radja pindòë - aneu ${ }^{s}$ miët nam dròë toepeuë basa pat njang djidoeës radja pindòë — aneus miët nam dròë djaras hana aneu $^{s}$ miët nam hana djithèë - la ${ }^{s}$ én lagèë piké radja radja kianòih njan dji kaphé - aneus miët nam tjré sabòh masa

485 bas masa njan hanatòm tjré - meung sipadé deungòn radja di wië lhèë dròë oeneun lhèë dròë — han sis oeròë njang han seureuta radja kianòih waham dji meunan - aneus miët nam djeuët ban kata djeuët ban djikheun djikira doedòë - djijoeë kheun dròë alah táala djibri peukajan meuih ngòn pira $^{s}$ - pandang galas sòë eu roepa

490 pat njang djidoeës hò njang djidjas ${ }^{s}$ - hantòm djaras aneu ${ }^{s}$ oelama lhèë dròë di oeneun lhèë dròë di wië - hantòm meusië ban djisadja njang lhèë dròë di wië djimat tjitjém - meunan kajém rōos -ró $^{s}$ masa njang lhèë dròë njan djimat peunoeman - dalam njan kleumba ${ }^{s}$ djeumpa tjitjém oetōïh that bit ragòë - djitoepeuë keudròë 'òh djibasa

495 'òh ka djiglib djitoepeuè lé - kleumbas hasé dalam piala 
kleumbas ${ }^{s}$ hasé dalam peunoeman -- teureubang tjitjém njan pantaïh sigra djimè ië mawò sabòh peunoeman - baranggadjan geunab masa minjeu $^{\text {s }}$ ata sabòh peunoeman - njan pi meunan djeuëb koetika kleumbas djeumpa sabòh peunoeman - neungcej radja gèt $\mathrm{dji}^{\mathrm{s}}$ adja

500 peunoeman meuïh deungòn intan - meuteurapan moepeureumata teuma djipeulheuëh tjitjém di djaròë — sit that ragòë goena biasa djiteureubang dalam peunoeman - lheuëh tjitjém njan maséng djeumba nibas $^{s}$ ië mawò sabòh djiblōh - tjitjém oetōih gèt $\mathrm{dji}^{\mathrm{s}}$ adja $\mathrm{ba}^{s}$ minjeu ${ }^{s}$ ata sabòh djidòng - tahe mantòng sòë eu roepa

$505 \mathrm{ba}^{s}$ kleumbas sabòh djidòng — $\mathrm{ra}^{s}$ jat teutjangang kalòn roepa $\mathrm{ba}^{s}$. kleumbas sabòh djidòng - doem teutjangang $\mathrm{ra}^{s}$ jat njang na hingga rata boelèë basah - teureubang pantaïh ateuëh radja djikeupa $^{s}$ sajeuëb itam mirah — meuhambō ië ateuëh radja lheuëh njan tjitjém maséng djiwòë $-\mathrm{ba}^{s}$ teumpat dròë aneus miët tiga

510 lhèë peunoeman mantòng asòë — aneu ${ }^{s}$ miët lhèë dròë wòë bas radja le that nèsmat radja pindòë - meuribèë bagòè sit doempetıë na peuë djipinta sit trōïh reudjang — tjitjém teureubang djipeuhamba ka neuloerōng oelé toehan - djeuët keu tèëlan binatang njang na sigala binatang sinan meukawan - loerōng toehan si tjilaka

515 djeuët ban djikheun trōih hadjat - loerōng halarat ateuëh dōnja radja kianòih that bit meugah - loerōng alah dalam dōnja le that nanggròe $\operatorname{ta}^{s}{ }^{-o^{s}}$ ba $^{s}$ djih — oesō habéh keunan teuka peuë njang djikheun doempeuë hasé — radja djahé asòë noeraka habéh $\operatorname{ta}^{s} 1 \bar{o}^{s} \mathrm{ba}^{s}$ djih moewòë - teuma djikheun dròë alah ta'ala

520 oemoe lhèëplōh thōn keuradjas an - loerōng toehan ateuëh dōnja haba kianòïh hana habéh — meung silapéh disinòë na haba kianòih that landjoet - lōn bōh batjoet meung keu poentja lōn tjò ${ }^{s}$ poentja ninan sipatah - meung lōn kisah haba èëlia haba èèlia asaj disinòë — njang ka djeuët njòë lōn tjò ${ }^{s}$ poentja

525 dilèe pi le radja njang la $a^{5}$ én - misé pra‘ōn meugah raja 'òh lheuëh pra'ōn meugah karōn -- meuïh djitamòn han és hingga misé meugah nameuroet deungòn 'at - bandoem la ${ }^{5}$ nat darōhaka hantòm sakét kaphé pindòë - djijoeë kheun dròë alah ta'ala han tjit sabé kianòih sidròë — meuribèë bagòë di djih bitjara

530 padoem lawét djikeuradjeuën - hantòm reuën-mareuën keudjih teuka hantòm sakét pi oelèë — hantòm lajèë meung ië moeka sit meung batō ${ }^{s}$ djih pi tan - loerōng toehan si tjilaka hantòm moemang pi meung sikléb — hantòm sakét sikléb mata hantòm timòh pi meung koedé — radja kaphé nè ${ }^{s}$ mat lam dōnja 535 djijoeë kheun dròëdji pòteu alah $-\mathrm{ra}^{s}$ jat djikrah sigala dōnja 
djikrah rasjat djeuëb-djeuëb nanggròë - djijoeë kheun dròë alah ta'ala sòë njang patéh djih njò toehan — djibri peukajan ngòn areuta sòë han patéh djipòh maté - that bit djahé si tjilaka oemoe lhèëplōh thōn teutab keuradjeuën - hantòm reuën-mareuën

keudjih teuka

540 lheuëh nibas njan teuma doedòë — radja pindòë rab binasa teukeudirōlah teuma doedòë — aneu ${ }^{s}$ miët nam dròë keumeung pòh radja aneus miët nam dròë djikheundas boenòh — radja kianòih rab binasa adat kòn trōïh sidròë meuntròë — radja pindòë ka binasa aneus miët nam dròë meutjoekèh-tjoekèh — teuma han djadèh djipòh radja

545 teuma teupiké dalam até dròë — kadang sòë teuma pòh bila radja pi tan geutanjòë pi maté - meunan piké maséng rata taleungò lōn peugah sidròë meuntròë - oereuëng njan tòë deungòn radja meuntròë peugah $\mathrm{ba}^{s}$ kianòï — gata djimeung pòh lé aneus oelama djimoepakat djihnjan nam dròë — gata sidròë djipoepahna

550 djikheun gata kaphé pindòë - tajoeë kheun dròë alah táala dèëlat toehankoe tjahi beudèëlat - lōn peusingat doeli sròëpada djikheun djipòh radja parisi - that djideungki toeankoe gata djikheun djipòh toeankoe boematé - djikheun kaphé keu doeli sròëpada meuntròë peugah djihareutòë - aneus miët nam dròë $\mathrm{si}^{s}$ at hana

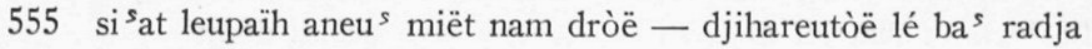
$a u^{s}$ miët nam dròë leupaïh $\mathrm{dja}^{s}$ manòë - meuntròë peuroenòë radja tjilaka

ban djileungò meuntròë peugah — radja goendah poetjat moeka poetjat ngòn moeka jò ngòn badan — rōt lé jōh njan ateuëh keuta koelahkama rōt di oelèë — kakeu lajèë ngòn ië moeka

560 sit njan phōn até goendah — teuka soesah radja tjilaka até goendah moeka hiram - jōh njan djidam aneus oelama jōhnjan djijoeë pòh aneus nam dròë $-\mathrm{ba}^{s}$ peudana meuntròë ngòn peutoea amabas doe teuma doedòë - aneus miët nam dròë lōn kheun nama tangò lōn peugah aneu ${ }^{s}$ nam dròë - djròh samlakòë koenangan radja

565 dilèë oentōng djih koenangan - wadi geupeunan 'òh ka raja nama njang phōn nan tamlékha - njan njang bidjas ${ }^{s}$ nibas njang na njang keudoea na tatoeri - nan geurasi makeusalémina mareutoenih nama njang lhèë - meunan meuteumèë dalam tjalitra ashāaboe'l-jamīn njan geupeunan - koenangan njan oeneun radja

570 nama njang keupeuët noenoenih - sareuboenih njang keulima paliaseutatioenih nama njang keunam - habéh tamam lōn peunjata ashāaboe'sj-sjimāl njan geupeunan — di wië radja njan aneus miët tiga 
di wië lhèë dròë oeneun lhèë dròë — radja pindòè sangat kaja lhèë dròë di wië lhèë dròë di oeneun — radja hireuën poetjat moeka

575 keureuna boenòë meuntròë peugah - njankeu goendah até radja hiram moeka jōh masa njan — 'òh trōih koenangan kalòn radja masa dilèë hana meunan - ba $^{s}$ oeròë njan beungèh radja koenangan kalòn moeka oebah — radja goendah até lam dada jōh njan tamlékha ka teupiké — ka meutjawé dalam dada

580 na sòë peugah narit geutanjòë - njankeu djinòë beungèh radja njang dilèë kòn hantòm meunòë — njò oeròë njòë oereuëng peuhaba salèh sòë leungò pakat geutanjòë - hantòm meunòë dilèë njang ka radja beungèh 'òh trōïh geutanjòë — njò na boenòë oerenëng peuhaba jōh njan tamlékha lòm neupiké - han djeuët dòng lé sinc̀ë ba ${ }^{s}$ radja

585 adat njang radja njòë toehan - pakòn ban énsan doem peukara makeuën minòm ban di kamòë — hana sapeuë njang na bida. doem peukara ban di kamòë — njò radja njòë manoesia sipheuët toehan hana meunan - teutapi han djidjeuët kata meung djikheun kòn djipòh maté — radja kaphé las nat raja

590 meung sòë kheun kòn radja njòë toehan — djikòh badan teuma djisoela oeròë malam dawōs neupiké - soesah keu até aneus oelama makeuën pi tan minòm pi han — tidō pi meunan doempeuë hana han lé djikira keu peukajan - teumanjòng jōh njan makeusalémina hé tamlékha pakòn goendah $-\mathrm{ba}^{5}$ lōn tapeugah hé tjèëdara

595 geutanjòë nam dròë hoekōm sabòh - peugah adòë djròh peuë keureuna teuma seus ōt moeda samlakòë — koepiké keudròë hé tjèëdara langèt manjang toempangdji tan — kòn njan toehan njang meuroepa langèt meugantoeng lōn kalòn hireuën — oeròë ngòn boeleuën sòë poeba-ba sòë hoeë boeleuën sòë bōh bintang — peungeuih bandrang sòë bōh tjahja

600 boemòë teuleuëng hana moemòt-mòt - pakri han hanjòt boekét njang na meunan teupiké lōn hé adòë — njang boemòë njòë pat geuhanta boemòë teudoeës sapat ngòn las ōt - pakri han hanjòt sòë plara djinòë lōn piké that teumakōt — 'òh djan seupōt oeròë hò geuba lòm teupiké keu oentōng dròë — jōh tjoet kamòë lam kandōng ma

605 jōh masa lōn lam kandōngan — panè keunan raseuki teuka sòë peugèt ban djinòë toebōh - panè oetōïh keunan teuka meung radja njan djeuët dji pi tan — pakri toehan dròë djikata pakri djijoeë kheun dròëdji toehan — oetöih dji tan doem peukara tjoeba piké doemteu djinòë — njò radja njòë njang plara

610 djih pi saban deungòn geutanjòë - pakri djinòë tòh bitjara toehan geutanjòe hana lakoean - hana saban mèë tapeusa hana djaròë hana gaki - meuhasoetji alah ta'ala 
radja njòë kaphé las natélah - beuthat djipeugah gadjah ngòn goeda beuthat djikheun bès tapatéh — radja paléh asòë noeraka

615 radja paléh kaphé pindòë — han thèè keudròë djih gòb peuna patōt djijoeë kheun dròëdji toehan — imandji tan kaphé tjilaka radja kianòïh loerōng alah — pagé balaïh di djih noeraka rakan leungò tamlékha peugah - doem geukeubah didalam dada rakan njang limòng djaweuëb jōh njan — sabét meunan ban kheun gata

620 sabét beuna ban tapeugah - hana salah ban takata kamòë njang limòng bitjara tan - bandoem sadjan keu ngòn gata ban njang takheun han moebantah - ban tapeugah meuseureuta meungnjò tas ${ }^{s}$ ikōt radja la ${ }^{s}$ nat - hana rahmat geutanjòë doemna meungnjò tapeugah radja njòë toehan — geutanjòë sadjan dalam noeraka

625 toehan bri adeuëb pagé doedòë - geutanjòè nam dròè sadjan radja tamlékha kheun jōh njan pantaïh — hana ilah meung kòn taboengka meukòn taboengka geutanjòë nam dròë — beudjis ōh nanggròë djinòe tasapa

meungnjò tadoeës sinòë sabé - han meudjan maté djis inanja na sòë leungò pakat geutanjòë - radja pindòë hiram moeka

630 pakat geutanjòè na sòë peugah - meunan oelah bangòn roepa hantòm meunòë njang ka dilèë - geuseu keu kèë meunan roepa pakat geutanjòë na sòë peuthèè - njankeu lajèë ngòn ië moeka njankeu lōn kheun han djeuët dòng lé — akhé maté djisinanja tatjré nibas radja tjèëtan - tawòë ba $^{s}$ toehan rabōnsama

635 toehan njang peudjeuët langèt boemòë — keunan geutanjòë hé tjèëdara njò moepakat geutanjòë nam dròë — tatjré djinòë hé adésnda - akhé meugah kadang doedòë — oereuëng nam dròë djadèh boengka tamlékha poeblòë kajèë sibas - keu pangkaj djas lasén hana lhèë bòh deureuham nanggròë parisi - boeët kianòih peugèt ria

640 siplōh maïh brat sabòh-sabòh - keuradjeuën kianòih djijoeë peuraja njankeu pangkaj njang na meuteumèë — siba ${ }^{s}$ kajèë djitoeëng hareuga 'òh saré lheuëh kajèë djipoeblòë - beudòìh samlakòë pasang goeda jōh njan djiboengka oereuëng nam dròë — djibòih nanggròë ka djisapa djibōh peulana teubiët oe blang - goeda djipasang doemdji rata

645 ka djibōh ngòn talòë keukang — jōh njan djipasang goeda pòh lawa ka djiteubiët oereuëng nam dròë - radja pindòë djithèë hana hana djithèë koenangan ploeëng - leupaïh djoerōng meudiwana teuma meutoetō sidròë rakan - bès lé tèèlan tapasang goeda takeubah goeda tadjas ngòn tapa ${ }^{s}-$ tiës $^{s}$ lé galas areuta radja

650 jōh njan moepakat oereuëng nam dròë — djitrōn oe boemòë doemdji rata goeda nam bòh sinan djikeubah - djitjòs langkah ka djiboengka 
toedjōh peureusah djis ōh djidjas - beusōt tapas darah keuloea sabab hantòm peudjalanan — ngòn sabab njan djeuët binasa teukeudirōlah printah halarat - meuteumeung ngòn sahbat di rèt raja

655 meuteumèë sidròë oereuëng di djalan — teukeudi toehan njang that kaja oereuëng toeëng oepah goebeuë kamèng — até hanèng soetji sapha djidoeë $^{s}$ di glé toeëng oepahan — njankeu rakan njang seutia moebri saleuëm oereuëng nam dròë — ka trōih bas kamòë keunòë bas gata asalamoe 'alòjkōm dalém meutoeah — printah alah meuteumèë ngòn gata

660 kamòë dalém apōh-apah - that sangat grah lapa dahga makanan pi tan minòman pi han — peuë na rakan djinòë bas gata kri tjit narit si goebeuë kamèng — até hanèng geumaséh raja djibri ië abin keu minòman — djibri makanan djabét keureuma oereuëng nam dròë padjōh makanan — nè mat jōh njan djati rasa

665 djipadjōh pi lheuëh nès mat hasé - oeròë njan lé teuka sindja $\mathrm{ba}^{s}$ malam njan teutab sinan — djibri makanan peuë hasé na niba $^{s}$ malam peugah-moepeugah - panè langkah dròëneu teuka panè gampōng dipat teumpat — peugah sahbat hò djas gata oelōn kalòn gata rakan - sang lakoean koenangan radja

670 panè tadjas hò neuhadjat - peugah sahbat deungòn sibeuna panè gata wahé rakan - lōn eu peukajan bas angèëta ngòn peukajan le ba ${ }^{s}$ asòë — salèh hò nanggròë tameung boengka salèh peuë sabab tabòih nanggròë — peuë na adòë peugah sigra peuë na sabab tabòih keuradjeuën - peuë reuën-mareuën salèh teuka

675 peugah ba $^{s}$ kamòë adòë meutoeah — takheun beusah adòë radja oereuëng nam dròë teuma peugah — habéh djikisah asaj boengka njang djeuët meutjré kamòë nam đròë — tangò djinòë lōn tjalitra kamòë njòë rakan radja kianòï — njò bit sahèh koenangan radja njang djeuët moeminah kamòë di nanggròë — radja pindòë tan agama

680 radja kianòih ka djikaphé — han djeuët dòng lé kamòë di tangga ka djijoeë kheun dròëdji toehan — radja tjèëtan asòë noeraka djikheun dròëdji pòteu alah — njankeu soesah kamòë doemna sòë han patéh djipòh maté — radja kaphé lasnat raja djijoeë seumah dròëdji bas kamòë — moeploeëng keunòë njan baròë sa

685 njankeu poentja moebòìh nanggròë — kamòë nam dròë meuteumèë ngòn gata meudòng di nanggròë baja keunòng — bahlé lam goenòng meudjas tapa njankeu sabab moebòih gampōng — mita oentōng njang sidjahtra adat meunan wahé adòë — lōn njòë sidròë sadjan taba meungnjò meunan ban tapeugah — di lōn goendah até lam dada

690 lōn pi han lé koedòng di nanggròë — akhé doedòë djeuët binasa

Deel 98. 
teuma tanjòng oereuëng nam dròë — namateu sòë geuhej gata sòë nan geuhej gata sidròë - peugah adoeën dròë bas kamòë njang na oereuëng doeë' di glé djihareutòe — bas oereuëng nam dròë djitjalitra oelōnteu njòë njang meutjeuhoe - dawōnoeanisoe geurasi nama

695 djinòë pi lōn djas taprèh sisat - lōn $\mathrm{dja}^{s}$ euntat kamèng tjèëdara lōn $\mathrm{dja}^{s}$ poelang kamèng rakan — lōn $\mathrm{dja}^{s}$ sadjan deungòn gata teuma djidja ${ }^{s}$ pantaïh reudjang — habéh poelang doem areuta 'òh trōïh keunan kamèng poelang - meu'ah abang lōn koeboengka kamèng djipoelang meu'ah djilakèë — habéh djiteuntèë doem peukara

700 kakeu djidjas ${ }^{s}$ ngòn oereuëng nam dròë — djibòih nanggròë takōt keu radja toedjōh ngòn njan nam dròè dilèë — djiseutèt asèë djeuët lapan ka asèë njan djròh roepa le ban — beusalahan geukheun oelama ladoem idjō koenèng meudjampō - ladoem kheun lakoe mirah roepa ladoem riwajat wareuna langèt - poetéh moemèt-mèt bangòn roepa

705 sang idja sōh ladoem peugah - meunan oelah ladoem roepa roepa le ban nama le that - le riwajat khileuëh oelama meunan teuseuboet $b^{s}$ kitab arab - asèë geuhisab le that nama meunan peuneugah dalam hisabi - sòjdina 'ali njang tjalitra neuleungò nibas rasoelōlah - doedòë neupeugah $\mathrm{ba}^{s}$ panita

710 doedòë nibas ${ }^{5}$ wapheuët nabi - tanjòng jahoedi neupeuhaha doedòë nibas njan teuma geukisah - ébeunoe 'abaïh njang tjalitra geuriwajat roepa asèë - le ban lagèë le peuë nama ébeunoe 'abaïh neukheun jōh njan — asèë djimeunan kateumi nama si kateumi djimeuhej nan — asèë djihnjan sadjan djiba

715 pò asèë njan dawōnoeanisoe - meunan teungkoe kheun oelama sit hantòm tjré djiba sadjan — keumeung meukawan asèë seureuta di toeanteu 'ali neuriwajat - asèë njan meuhat diarah nama si diarah djimeuhej nan — di noeanisoe njan njang plara njan nan neukheun di toeanteu 'ali - hana sabé khileuëh oelama

720 di 'èdrasi neukheun jōh njan - asèè djipeunan kiteurab nama si kiteurab djimeuhej nan — asèë djihnjan gèt $d j i s$ adja di 'èdras $i$ kheun njan nan asèë — di meudjahit njan neukheun sahia si sahia djimeuhej nan — asèë djihnjan gèt $d j i^{s}$ adja di meudjahit neukheun njan nan — di soe'ib jōh njan lasén tjalitra

725 di meusoe'ib neukheun jōh njan — asèë djipeunan ahma nama si ahma djimeuhej nan — asèë djihnjan mirah wareuna di meusoe'ib meunan neupham - abeudōlah salam la ${ }^{s}$ én kata abeudōlah bin salam jōh njan neukheun - katiroelabila geurasi nama si labila djimeuhej nan — asèë djihnjan bidjas sana

730 abeudōlah bin salam neukheun njan nan — di wahab jōh njan lasén tjalitra 
di wahab neukheun jōh njan - asèë djipeunan takat nama si takat djimeuhej nan — asèë djihnjan djigaséh raja di wahab neukheun njan nan - aboe hanipah jōh njan lasén tjalitra di aboe hanipah neukheun jōh njan — asèë djipeunan kitamoen nama

735 si kitamoen djimeuhej nan — asèë djihnjan tjeureudés raja aboe hanipah neukheun njan nan - oelama lasén lòm khileuëh na nama le that roepa le ban - meunan tèëlan dalam tjalitra si kateumi ladoem kheun nan — asèë djihnjan idjō wareuna han é $^{s}$ habéh sòë keutahwi - malingkan rabi thèë sibeuna

740 kata moehamat ébeunoe manjèt - asèë njan sabét teulheuëh njan nama teulheuëh djimeuhej nan — asèë djihnjan koenèng wareuna ahlōjtapeusé le that khileuëh - teutapi alah thèë sibeuna njang riwajat ébeunoe 'abaï — si kateumi sah neukheun nama si kateumi seutèt di likōt - oereuëng peudhōt poera-poera

745 djidjas ${ }^{s}$ keu oereuëng njan toedjōh dròë — asèë sidròë sadjan djiba oereuëng dilèë asèë di likōt - teuma djidhōt poera-poera tamlékha kheun njan $b a^{s}$ rakan - kateumi sadjan njan bès taba si kateumi bè ${ }^{s}$ taba sadjan — 'ajéb tèèlan njeum di mata sang-sang 'ajéb djih di likōt - pakri patōt rakan bas gata

750 oereuëng nam dròè teuma seu ${ }^{s} \bar{o} t-$ pakòn tadhōt bahlé seureuta oereuëng pò kheun teuma batjoet - bahlé kadhōt na djigisa kateumi leungò meunan geukheun kri - lipat gaki pantaïh sigra djab ngòn dada jōh njan oe boemòë — seureuta djimòë ngòn ië mata seureuta djis oetjab doea kalimah - bè ${ }^{s}$ takeubah oelōn taba

755 jōh njan djikheun lā ilāha illā'llāh - nābì mōesā kalāmoellāh $\mathrm{koe}^{s} \mathrm{e}^{s} \mathrm{sa}^{s}$ si pòkoe toehan - hana saban misé hamba hana djaròë hana gaki - meuhasoetji alah ta'ala koe'és sa $^{s}$ si moesa njò nabi — soerōh rabi neujoeë keureudja oelōnteu njòë bè ${ }^{s}$ tatinggaj - oelōnteu kawaj doemna gata

760 koelakèë doe'a oeba ${ }^{s}$ toehan -- beukòng iman teungkoe doemna lōn lakèë beuteutab gata toedjōh dròë — radja pindòë bès djimita beuseulamat dōnja akhirat - bès na sapat meuteumèë baja barangri baja pi bès keunòng - beutoehan peutamòng dalam tjeuroega oereuëng toedjōh dròë djipoedjòë toehan — djiba sadjan oe lam rimba

765 oereuëng toedjōh dròè lapan ngòn asèë — meunan meuteumèë dalam tjalitra oereuëng toedjōh dròë teungòh oe glé - meuteumèë lé sabòh goeha disinan meuteumèë goeha batèë - gèt that lagèë indah roepa djabajkoeloeïh nama glé njan - ramét djimeunan nama goeha goeha that djròh moeplinggam — kroeëng didalam ië moemata 
770 pintō goeha oebit langgam - loeaïh didalam siteuntang mata dalam goeha jōh masa njan - le that disinan djabét keureuma padoem-padoem ngòn ba $^{s}$ kajèè — njang mangat bèë gahroe tjeunana djabét keureuma masas di bas ${ }^{s}$ tapadjōh galas djati rasa masas di ba ${ }^{s}$ rōt bas tangké - tapadjōh lé ban njang hawa

775 dalam tapeusé meunan peuneugah - ébeunoe 'abaïh pò tjalitra oereuëng toedjōh dròë peutrōïh keunan — geutamòng jōh njan

bandoem rata

asèè diloea di djih teumpat - djikeumiët meuhat pintō goeha si kateumi keumiët di pintō — oereuëng laloe doem djisangga oeròë malam teungeutdji tan — baranggadjan djimeudjaga

780 djikeumiët pintō di djih lalòë — oereuëng toedjōh dròë teutab lam goeha amaba'adoe teuma doedòë - oereuëng toedjōh dròë pansan lam goeha $\mathrm{ba}^{s}$ "èdrasi peureuman toehan — neujoeë trōn jōh njan oe lam dōnja hé "èdras ${ }^{s} i$ katrōn lam goenòng - kadjas toeëng njawòng asòë goeha

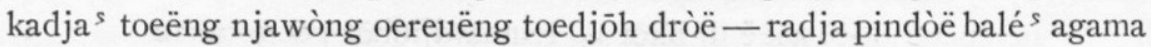

785 'èdra ${ }^{s}$ i ngò peureuman toehan — geutrōn jōh njan pantaïh sigra "èdras ${ }^{s}$ trōn dalam goenòng - neudjas toeëng njawōng asòë goeha neudjas $^{s}$ toeëng njawòng oereuëng toedjōh dròë — radja pindòë

$$
\text { bè }^{\text {s }} \text { djisoela }
$$

"èdras ${ }^{s}$ t trōn dalam goeha njan — oereuëng toedjōh dròë sinan pahna si kateumi kawaj di pintō - deungòn kheundas pò toehan asa

790 djiśéh di pintō disinan sabé - deuës dji han lé grah pi hana hana djiwèh asèë disinan — printah toehan njang koeasa oereuëng toedjōh dròe sinan pansan — peureuman toehan njang koeasa toehan joeë trōn asòë langèt - plara manjèt dalam goeha sidròë-dròë manjèt doeaplōh mala sikat - toehan halarat joeë plara

795 djibalés wië deungòn oeneun — sithōn siseun meunan keureudja sithōn siseun manjèt djibalés - bès kamoeë é $\mathrm{e}^{s} \mathrm{ba}^{s}$ angèëta sit djeuëb-djeuëb thōn meunan soentō $\bar{s}^{s}$ - nameung bè ${ }^{s}$ brō ${ }^{s}$ toebōh meulia 'òh trōïh-trōih bas boeleuën mèhram — disinan tapham toebōh meugisa siplōh oeròë boeleuën mèhram - sinan gata pham nan atjoera

800 ba $^{s}$ boeleuën mèhram siplōh oeròë - manjèt toedjōh dròë malas ${ }^{s}$ ikat gisa mata oeròë toehan soerōh - neujoeë peutrōin dalam goeha na thō toebōh bè $\mathrm{e}^{s}$ brō $^{s}$ djasat - soerōh halarat keupadanja djis ${ }^{s} s$ oeròë njan oe langèt - di oeneun manjèt keunòng tjahja djilōb oeròë blah wië keunòng - ateuëh goenòng dalam goeha

805 aseuhabōjkapi teudoeës $\mathrm{si}^{s}$ at - moewòë riwajat oebas radja kata sahéb pò koerangan — teumanjòng jōh njan radja tjilaka 
ka djiteubiët jōh masa njan — djis eu koenangan teuka hana aneus miët nam dròë hò ka leupain — tjoeba peugah hò djiboengka seu $^{s}$ òt ra ${ }^{s}$ jat tandi boedjang — keunan oe blang njan djisapa

810 keunankeu boenòë kamòë pandang - djiteubiët oe blang pasang goeda trōïh an djinòë hana djiwòë — salèh hò nanggròë ka djiboengka keunankeu rèt boenòë oe toenòng - salèh lam goenòng $\operatorname{djidja}^{s}$ tapa djidjas mita la $^{s}$ én toehan — keu gata han djipeutjaja $\mathrm{ba}^{s}$ peunjeum lōn djiploeëng leugat - lawét njòë that doekatjita

815 silawét neukheun dròëneu toehan - aneus miët nam doekatjita njang dilèë kòn hana meunòë — oereuëng nam dròë djaras ${ }^{s}$ hana hana tòm tjré aneus miët nam dròë — toeankoe sidròë djigaséh raja 'òh neukheun dròëneu pòteu alah - njan phōn soesah aneu ${ }^{5}$ oelama hana djipatéh toeankoe toehan — aneus miët nam ka djiboengka

820 na njeum kamòë njò ka djiploeëng — salèh lam goenòng djidjas tapa meuri djidjas ${ }^{s}$ hana djiwòë - aneus miët nam dròë hò salèh ka meukeumeung tham moepòh maté - teutōb até kamòë doemna hana meugras gaki djaròë — aneus miët nam dròë leupaih boengka djipasang goeda aneus miët nam dròë — $\mathrm{ra}^{s}$ jat meukatòë kalòn roepa

825 bit pi meunan han sòë tanjòng - tahe mantòng hana haba ban radja ngò meunan peuneugah — $\mathrm{ra}^{s}$ jat djikrah sigala dōnja djijoeë djas ${ }^{s}$ mita aneus ${ }^{s}$ miët nam dròë — ban sabòh nanggròë djisranta lapanplōhribèë goeda djibri - kandreuën parisi $\mathrm{dja}^{s}$ moemita djibri haba djeuëb-djeuëb nanggròë — aneu ${ }^{s}$ miët nam dròë djijoeë mita

830 toedjōh oeròë djikrah ra ${ }^{s}$ jat — habéh meusapat doem barang na toedjōh oeròë djikrah sabé — $\mathrm{ra}^{s}$ jat ilé djeuëb-djeuëb dōnja njan teupiké doemna $\mathrm{ra}^{s} \mathrm{jat}$ - meutjawarat ban sineuna njang djeuët djiploeëng aneus ${ }^{s}$ miët nam dròë — djijoeë kheun dròë alah táala

kòn radja njan pòteu alah - njankeu soesah aneus oelama

835 djakalèë njò radja njòë toehan - aneus miët ban nam han djiboengka hana patōt djiwèh sinan - aneus miët ban nam aneus oelama meunan teupiké doem $b^{s}$ até — hana lahé njan djikata djikheun kòn toehan hana lahé — djitakōt maté djipòh lé radja le that $\mathrm{ra}^{\mathrm{s}}$ jat meunan piké — radja kaphé djibòih agama

840 siteungòh $\mathrm{ra}^{\mathrm{s}}$ jat njan bas até — 'òh djipiké gadòh bitjara han djeuët kheun njò han djeuët kheun kòn — sabab djikalòn doem peukara

pakri radja njòë salèh toehan - salèh sit kòn ba $^{5}$ geukira peuëkeu sabab njang djeuët meunan - èleumèë han didalam dada jōh masa njan djahéliah — oebah-oebah nibas agama 
845 meudjan-djan njò meudjan-djan kòn — 'òh djikalòn doem peukara le that $\mathrm{ra}^{\mathrm{s}}$ jat han trōih piké - han meu'òh lé sòs ${ }^{\text {-sòs }}{ }^{s}$ sangka siteungòh kheun njò siteungòh kheun kòn - meunan bangòn $\mathrm{ra}^{\mathrm{s}}$ jat doemna djahéliah "èstikeuët le ban - mas ripat keu toehan èleumèë hana han djitoe'òh keu mas ripat - èleumèë singkat dalam dada

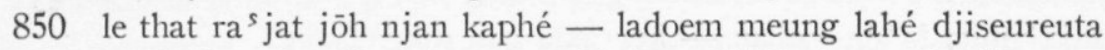
sabòh bangòn djitakōt meung lahé - djiniët bas até asòë noeraka djikeumeung kheun kòn han moepakat - le that ras jat radja tjilaka le njang $\mathrm{ta}^{s} \overline{l o}^{s} \mathrm{ra}^{s}$ jat keunan — ngòn sabab njan han djeuët djikata jōh njan $\mathrm{ra}^{s}$ jat habéh meusapat — djiboengka leugat han djeuët meudas wa

855 djijoeë mita aneus miët nam dròë — ra sjat meukatòë jōh njan boengka lapanplōhribèë goeda djibri - kandreuën parisi djas moemita djiseutèt euntjit masa djidjas - beukaïh tapa ${ }^{s}$ gidoeë $^{s}$ goeda hingga trōih $\mathrm{ba}^{s}$ sabòh goenòng — $\mathrm{ra}^{s}$ jat djitamòng dalam rimba ras jat peutrōïh dalam goenòng - meuteumeung sinan sabòh goeha

860 djipoewèh asèë jōh masa njan — djitamòng keunan ra ${ }^{\text {sjat doemna }}$ jōh masa njan teumakōt asèë — djis eu meurèë-rèë ra ${ }^{s}$ jat teuka djiminah asèë sinan $\mathrm{si}^{s}$ at — djipeurab $\mathrm{ra}^{s}$ jat oe pintō goeha djiprèh diloea ladoem $\mathrm{ra}^{\mathrm{s}}$ jat — ladoem leugat tamòng lam goeha njang prèh diloea that bahrōlah — djahéliah tamòng lam goeha

865 djahéliah na tatoeri — niët ba $^{s}$ até sòs ${ }^{s}$-sòs sangka radja pi kòn djimeuniët toehan - las én pi meunan sòs ${ }^{s}$-sòs ${ }^{s}$ sangka njankeu oereuëng djahéliah - mas ripat keu alah èleumèë hana djahéliah tamòng keunan — lam goeha njan doem dji rata 'òh saré leupaïh djitamòng keunan — djis eu oereuëng njan

870 neupeutrōn éleuham oelé alah — djahéliah gèt that bitjara teungeut indra neubri éleuham oebas até - sit leumah lé akaj bitjara djahéliah habéh moepakat - tapeungeut $\mathrm{ra}^{s}$ jat euntreu ${ }^{s}$ diloea $\mathrm{ra}^{s}$ jat diloea euntreus tapeungeut - oereuëng njan teungeut takheun hana boe moepakat doem geutanjòë — aneus miët nam dròë takheun hana

875 hana meuteumeung aneu ${ }^{s}$ miët nam dròë — salèh hò nanggròë ka djiboengka salèh habéh ka rimoeëng plah - meunan tapeugah euntreus oeloea aneus miët nam dròë han meuhò lé — salèh ka maté dalam rimba meunan pakat doem geutanjòë — oedéh djinòë teubiët oeloea meung kòn meunan tapeungeut $\mathrm{ra}^{\mathrm{s}}$ jat — djipòh meuhat asòë goeha 880 djipòh lé radja anẹ ${ }^{s}$ miët nam dròë — 'òh trōih oe nanggròë teuma djisoela 
habéh bandoem djipòh maté - radja djahé lasnat raja djitōt manjèt djibōh lam apoej — toetōng rangoej adeuëb séssa djahéliah marit keudròë-dròë — aneus miët nam dròë djisangka indra djisangka teungeut aneus miët nam dròë — hana djipeugòë doem dji rata 885 pakri djeuët djikheun aneus miët nam dròë — toedjōh lagòë sapat lam goeha teuma djiseus ${ }^{s}$ tt sidròë rakan — meuteumeung di djalan kadang djiba djahéliah keumaih pakat - djiteubiët leugat doem oeloea djitakōt 'òh djaga habéh teukeudjōt — ploeëng teumakōt njan oeloea teuma djidròb oelé $\mathrm{ra}^{5}$ jat - djiba leugat oeba ${ }^{5}$ radja

890 njankeu sabab han djipeugòë - teubiët sinaròè doem oeloea djahéliah teubiët leugat - djipeungeut $\mathrm{ra}^{\mathrm{s}}$ jat njang diloea hana meuteumèë aneus miët nam dròë — oedéh tawòë geutanjòë doemna salèh hò-hò njankeu djiploeëng - salèh rimoeëng padjōh doemna salèh peuë goenòng njankeu maté - bè ${ }^{s}$ tadòng lé tawòë $\mathrm{ba}^{s}$ radja

$895 \mathrm{ra}^{s}$ jat diloea leungò hareutöë -- habéh djiwòë doem dji rata trōih $\mathrm{ba}^{s}$ radja $\mathrm{ra}^{s}$ jat djiwòë — aneus miët nam dròë djikheun hana hana meuteumèè aneus ${ }^{s}$ miët nam dròë — salèh hò nanggròë ka djiboengka dèëlat toeankoe han meuhò lé - salèh ka maté dalam rimba djeuëb-djeuëb seuroekan tan meuteumeung - njankeu oereuëng meudjas mita

900 salèh peuë goenòng njankeu djiploeëng - salèh rimoeëng gadjah seuba oedéb maté hana meukoesoeïh - radja kianòïh han lé haba padoem lawét hansòë toe'òh — kakeu gadòh hansòë djas mita hingga maté radja kianòih — oereuëng toedjōh dròë teutab lam goeha radja lasnat maté ka tréb - jōh njan cedéb asòë goeha

905 kata sahéb pò riwajat — oedéb meuhat asòë goeha lhèëreutōïh thōn ngòn sikoereuëng - hantòm oereuëng keunan teuka padoem-padoem radja meugantòë — oereuëng toedjōh dròë gòhlòm djaga meunan teuseuboet dalam koeroe ${ }^{s}$ an - peureuman toehan njang meulia le that radja la ${ }^{s}$ én meugantòë — oereuëng toedjōh dròë gòhlòm djaga

910 silajeuë keuradjeuën abeudōrahman - jōh masa njan oedéb rata nabi isa oe langèt ka tréb - barō oedéb asòë goeha keuradjeuën 'isa lam nanggròë njòë — oereuëng toedjōh dròë teungeut indra nabi 'isa mès reuët oe langèt - mantòng teungeut asòë goeha radja djōmdjōmah maté lòm doedòë — oereuëng toedjōh dròë gòhlòm djaga

915 nabi 'isa neumès reuët ka tréb - barō oedéb oereuëng lam goeha masa keuradjeuën abeudōrahman — jōh masa njankeu phōn djaga 
toehan peusoedéb oereuëng toedjōh dròë — njawòng neupoewòë

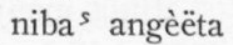

karōnja toehan njawòng neubōh - sigò ban toedjōh siseun djaga iradat toehan meuleuha koedrat - kèëwasa that alah táala

920 kata sahéb pò riwajat - teudoeës lé meuhat asòë goeha 'òh ban djikalòn mata oeròë - tahe keudròë sipeungandja mata oeròë djiseu ka manjang - jōh njan teutjeungang bandoem rata na sigalah mata oeròë — marit sidròë njang peutoea nama geuhej nan tamlékha - sangat bidjas nibas njang na

925 tamlékha kheun jōh njan ba ${ }^{s}$ rakan - toewò keu toehan teungeut indra simalam soentō ${ }^{s}$ ta $^{s}$ éh seunang - keu seumajang han takira na sikeudjab theuëh djikheun njan — beıdòih sinan poenjò mata djidjas $^{s}$ oeneun djidjas oewië — djimita ië han sapat na kroeëng habéh thō kajèë maté - ōndji han lé ba ${ }^{s}$ tinggajnja

930 tjabeuëng ka brōs $\mathrm{ba}^{s}$ treus tinggaj - hireuën akaj ngòn bitjara $\mathrm{ba}^{s}$ pi ka brōs tjabeuëng han lé - gadòh piké geutanjòë doemna proeëtteu pi deuës lagi ngòn grah - pakri ilah ngòn bitjara djabét keureuma han lé meung bas ${ }^{s}$ - boekòn that deuëes geutanjòë doemna ië han sapat makanan tan - bas sòë rakan na blandja

935 seu $^{s}$ òt tamlékha tanjòng rakan $-\mathrm{ba}^{s}$ lōn toean na blandja tabri dalém keu lōn peukajan - idja di badan alat meusapa tamlékha teubiët jōh njan sidròë — rakan nam dròë tinggaj lam goeha teubiët lam goeha djidjas ${ }^{s}$ sidròë — òh trōih oe nanggròë lalòë mata sira djidjas tahe keudròë - djiseu nanggròè kòn ban njang ka

940 ròt han meuhò peukan han moepat - hireuën dasah gadòh bitjara hana moepat lé peukan sòt - paléng palòt oereuëng moeda na sikeudjab tahe hireuën - leumah keu mideuën djiseu roepa laloe djipeurab njan bas pintō - disinan tahe sipeungandja meusoerat kalimah ba ${ }^{s}$ pintō mideuën — jōh njan hireuën oereuëng moeda

945 lā ilāha illā'llāh 'ìsa rōẹ allāh — djibatja pantaïh kalimah meulia njan meusoerat $\mathrm{ba}^{s}$ pintō mideuën — djikalòn hireuën lalòë mata djikoetjōb babah moeda samlakòë — doea djaròë rahōb moeka na sikeudjab teuma doedòë — oereuëng lakòë keunan teuka njan habaran geumeuhej nan — teumèë jōh njan di pintō raja

950 di pintō mideuën meuteumèë disinan - oereuëng lakòë njan djidja ${ }^{s}$ landja tamlékha tanjòng jōh masa njan — hadjat oe peukan trōn oe banda tamlékha deungò meunan hareutòë — oelōnteu sidròë teungkoe neuba neuba oelōn teungkoe oe peukan - lōn dja $^{s}$ sadjan deungòn gata habaran seu ${ }^{s}$ ōt éntjasalah - peuë na salah dja $^{s}$ oedéhta

955 na sikeudjab njan beudjalan — trōih oe peukan oereuëng doea 
'òh saré trōih njan oe peukan — geutamòng sadjan siseun doea tamlékha tanjòng bas habaran - peuë lakab nan nama banda peuë nan mideuën teungkoe peugah — sòë kaliphah peuë nan radja habaran peugah jōh masa njan - abeudōrahman nama radja

960 nama radja abeudōrahman - keusoeïh geupeunan nama banda tamlékha deungò habaran peugah - hireuën dasah até lam dada tamlékha kheun jōh masa njan - tablòë makanan teungkoe lé gata njòë deureuham wahé tèëlan — tablòë makanan keu kamòë hamba habaran kalòn deureuham njan — 'adjab jōh njan akaj bitjara

965 rajeus deureuham siplōh maïh brat - tahe ra $^{s}$ jat ban sineuna habaran tanjòng ba samlakòë — pat hé adòë tameuteumèë peudeuna di lōn ladoem adòë meutoeah - meung han lōn peugah oebas radja tamlékha seus ōt dami alah — djimeusoempah kòn peudeuna sibas $^{s}$ kajèè oelōnteu poeblòe — na lhèë oeròë ba ${ }^{s}$ lōn kira

970 oelōnteu boengka di madinah — hana koeseumah radja tjilaka keuradjeuën kianòïh radja pindòë — na lhèë oeròë tjré ngòn hamba habaran leungò tamlékha peugah - boekòn brakah narit gata hana patōt takheun meunan — keureuna radja ka tréb pahna lhèëreutōih thōn ngòn sikoereuëng — doemnan djameun sit ka lama

975 padoem-padoem radja meugantòë — 'adjab that kamòë narit gata teuma meutjeuhoe didalam peukan - keuleungòran trōih ba $^{s}$ radja meugah ba $^{s}$ radja abeudōrahman — geupanggé jōh njan oereuëng moeda geuba oedalàm jōh masa njan — ras jat sadjan meuribèë $1 a^{s}$ sa tamlékha pi trōïh jōh masa njan — radja tanjòng neuparés sa

980 abeudōrahman neuteumanjòng — panè oereuëng keunòë teuka djaweuëb boedjang sabda soeloetan — meuteumèë di peukan doeli sròëpada meuteumèë ngòn kamòë toeankoe boenòë — oereuëng moeda njòë keunòë moeba meukalòn $\mathrm{ba}^{s}$ djih deureuham djameun — meutanjòng djikheun kòn peudeuna djikeumeung moeblòë toeankoe boenòë — bas peunjeum kamòë njò peúdeuna

985 padoem bòh goetji salèh djiteumèë - toeankoe lakèë bas oereuëng moeda toeankoe lakèë di geutanjòë ladoem — meunan moephōm adat njang ka patōt toeankoe trimòng boeloeëng - bagi limòng misé njang ka sabòh bagi milés djoendjōngan — njang ka meunan hoekōm sròëpada di djih han djitém peugah ban teupat - salah njan that teumeureuka

990 radja tanjòng jōh masa njan - ba ${ }^{s}$ oereuëng njan neuparés sa hé oereuëng moeda takheun beusah - tjoeba peugah njang sibeuna tamlékha jōh njan ka djingadoe - di lōn toeankoe hana peudeuna 
dèëlat toeankoe tjahi alam - lhèë bòh deureuham njang na bas hamba sibas kajèë oelōnteu poeblòë — barō lhèë oeròë bas lōn kira

995 oelōn poeblòë kajèë siba s — lōn ploeëng nibas ${ }^{s}$ radja tjilaka soeloetan kianòih radja parisi — djimeus oengki keu agama djijoeë kheun dròëdji pòteu alah — sòë han seumah habéh djisoela manjèt djitōt dalam apoej — toebōh rangoej djeuët keu badja meunankeu boeët radja kianòih - $\mathrm{ra}^{\mathrm{s}}$ jat djiboenòh ban sineuna

1000 teukeudirōlah meuleuha koedrat - moeploeëng leugat dalam rimba djabaj koeloeïh nama glé njan — ramét djimeunan nama goeha dalam goeha njan kamòë sòm dròë — barō lhèë oeròë ba ${ }^{s}$ lōn kira na simalam teungeut disinan — djaga niba ${ }^{5}$ njan njòëhò lōn hala kamòë doem deuës makanan tan - keulaparan hana tara

1005 oelōn teubiët tinggaj rakan - lōn trōn oe peukan djas moemita oelōn djas keunòë mita makanan - tinggaj rakan sidéh lam goeha mideuën keusoeïh toeankoe kamòë — dalam nanggròë njòë roemòh tangga dèëlat toeankoe seumah laman - kamòë koenangan radja tjilaka djijoeë kheun dròëdji pòteu alah — hana meuseumah moeploeëng lam rimba

1010 radja kianòih bit that $\mathrm{la}^{\mathrm{s}}$ nat - le that ras jat djisinanja djigoebeuë kamèng sidjihnjan dilèë — hana sòë thèë ka djeuët keu radja ampōn toeankoe oelōnteu keunaj — meung na tinggaj mantòng tangga ébeunoe katén bapa lōn sinòë — dalam nanggròë njòë rab ngòn radja dèëlat toeankoe roemòh disinòë — dalam nanggròë njòë iboe bapa

1015 asaj dilèë di madinah - teuma moeminah keunòë bas radja silajeuë keuradjeuën malés salèh - doe lōn neuwèh keunòë neuboengka 'òh maté njan las én meugantòë — radja pindòë reulòih agama tamlékha peugah djihareutòë — harah teumpat dròë roemòh tangga habéh djipeugah meujoeb manjang — hireuën teutjeungang jōh njan radja

1020 sabda radja neujoeë euntat — oebas teumpat njang djikata tamlékha jōh njan ka geus euntat - djiseutèt ras jat sadjan seureuta tamlékha peutrōīh geuseuntat oe gampōng — tamòng djoerōng leumah tangga

ra'jat peutrōih és oe roemòh — djihej mèh-mòh asòë tangga salèh sòë na di roemòh njòë — tatrōn keunòë na peuë haba 1025 asòë roemòh leungò meunan — trōn lé jōh njan oereuëng toeha oereuëng toeha njan that bit datō ${ }^{s}$ - ka djareuëng $\bar{o}^{s}$ di koepala $\mathrm{si}^{s}$ ōn- ${ }^{s}$ on treus tinggaj di ateuëh — poetéh sang gapeuëh poetéh raja oemoe ka djameun hana lagèë $-\bar{o}^{s}$ di oelèë moepoeta-poeta boengkōs ngòn roeëng koelét ka krōt - keunèng karōt teutōb mata

1030 oereuëng toeha njan seusōt sidròë — salèh sòë meuhej kamòë hamba sòë njan di joeb meuhej kamòë — panè nanggròë sòë nan gata 
$\mathrm{ra}^{s}$ jat seus ōt oereuëng toeha njan — dèëlat soeloetan soerōh bas gata njankeu djeuët trōih kamòë keunòë — oereuëng moeda njòë keunòë neujoeë ba oereuëng moeda njòe kheun bas kamòë — njang roemòh njòë kòn di gata djikheun baròë djitjré sinòë — sòë joeë doeë ${ }^{s}$ njòë oebas gata djinòë pi tawèh gata sinòë — njang roemòh njöë kòn di gata oereuëng toeha ngò narit meunan - beungèh jōh njan hoe ngòn mata oereuëng toeha kheun ngòn amarah - tjoeba peugah sòe nan gata meung ka meunè meung ka meusòë — patōt moebòïh dròè hò langkah ba

1040 boekòn lé oetōin tadjas ${ }^{s}$ teumaki - that beurani até gata roemòh di lōn sit koekoe bri - le that taki lagòë ba ${ }^{s}$ gata éntoekoe tinggaj di lōn roemòh njòë — pakòn meunòë sabda radja oereuëng toeha njan sangat amarah - tamlékha peugah sipatah haba teumpat tamlékha nama kamòë - njang roemòh njòë éntoe hamba -

1045 ébeunoe katén nama ajah - baròe sa leupaih kamòë lam rimba tinggaj ajah lōn disinòë - leupaïh kamòë dalam rimba radja kianòih alòjhi la ${ }^{5}$ nat - toehan halarat dròë djikata sòë han patéh djih pòteu alah — djikòh lidah badan djisoela manjèt djitōt dalam apoej - toetōng rangoej hangōïh angèëta

1050 di kamòë moeploeëng dalam goenòng — ladjoe meutamòng dalam goeha djabaj koeloeih nama glé njan - ramét djimeunan nama goeha oereuëng toeha ngò narit meunan — teus ingat jōh njan 'adjab raja peuë tjit baròë njan tapeugah - sit bahrōlah njan ka lama lhèëreutōïhsikoereuëng thōn radja ka maté - han moepat lé doem peukara oereuëng toeha njan barō teus ${ }^{\text {singat } ~-~ s o e d j o e t ~ k h o ̄ d e u m a t ~ b a s ~}$ oereuëng moeda barō teus'sngat keu oereuëng gadòh - dilèë meuteus'òh ngòn nabi 'isa 'isa peugah jōh sabòh ròë - oereuëng toedjōh dròë dalam goeha masa keuradjeuën radja kianòih - nam dròë gadòh koenangan radja oereuëng geumoebeuë sadjan sidròë - meunan sabòh ròe haba "isa

1060 oereuëng toedjōh dròë lapan ngòn asèë — isa bri thèë oentōng moeda meunan teu'singat barō teupiké - neusoedjoet lé oereuëng toeha seumah di gaki tjōm di djaròë — koe tjhis kamòë lagòë gata

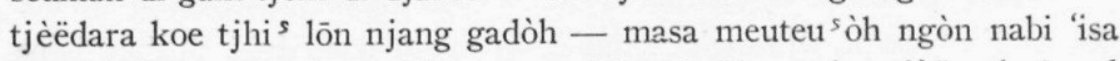
seumah keu ra ${ }^{s}$ jat ban sabòh nanggròë — trōïh moeboenjòë oebas radja 1065 radja joeë euntat boenòë keunòë — oereuëng moeda njòë ba ${ }^{5}$ oereuëng toeha

sabétkeu beuna ban teupeugah - radja pantaih brangkat oeloea radja pi jōh njan neubrangkat - neudja $^{s}$ peu'èdat oereuëng moeda sabét ban kheun oereuëng moeda njan — abeudōrahman djas poemeulia 
radja peutrōïh rab ka keunan - neutrōn jōh njan di tjōng goeda

1070 njang phōn radja moemat djaròë — lheuëh njan doedòë doem panglima

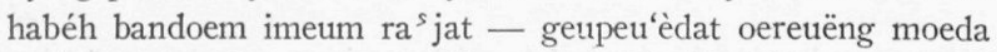
radja ngòn $\mathrm{ra}^{s}$ jat doeës meuhimpōn — djaròë djiseus ōn ateuëh djeumala lheuëh mat djaròë doeës meuhimpōn - lakèë ampōn bas oereuëng moeda radja teumanjòng teuma doedòë — rakan nam dròë hò salèh ka

1075 tamlékha seus ōt radja teumanjòng — mantòng lam goenòng sidéh lam goeha

sabda radja bas tamlékha - oedéh rakan djinòë lam goeha taba kamòë kalòn piasan — peuë ròë boeëtan toehan dalam goeha tamlékha seu ōt reudjang pantaïh — peuë na salah djas oedéhta amaba'adoe nakeu $\mathrm{si}^{\text {s }}$ at — neujoeë krah ras jat oelé radja

1080 neumeung djas sadjan ngòn samlakòë — neumeung djas eu pròë dalam goeha neumeung $\mathrm{dja}^{\text {s }}$ kalòn peuroesahan - peureuboeëtan toehan wahidò̀kaha habéh geukrah jōh njan rasjat - doeli halarat kheundas meusapa habéh meusapat sigala $\mathrm{ra}^{s}$ jat - kheunda $^{s}$ brangkat soeloetan radja geutjhis waki tandi boedjang — oelèëbalang imeum peutoea

1085 wadi kali peudana meuntròë — ras jat sinaròë sadjan seureuta habéh meusapat doem sibarang - panglima prang ngòn sabanda habéh meuhimpōn ngòn sipas ${ }^{\mathrm{i}}$ - sigala paki ngòn oelama saré habéh $\mathrm{ra}^{s}$ jat keunan — abeudōrahman brangkat oeloea radja jōh njan neubrangkat — habéh meusapat balatantra

1090 amaba'adoe mas na kōmdian — djiseutèt sadjan sabòh treus radja katá sahéb ampoenja rawi - nasrani djadèh boengka di djih pi le that habéh meusapat — djiba ras jat ngòn peutoea radja nasrani sadjan brangkat - padoem ngòn ras sat balatantra doea radja brangkat oe goenòng — han peuë tanjòng balatantra

1095 radja éseulam ngòn radja kaphé - - han peuë tanjòng lé balatantra 'òh saré trōih ras jat keunan - tamlékha jōh njan kheun bas radja ampōn toeankoe djaròë gaki — $\mathrm{ra}^{5}$ jat bès tabri tamòng lam goeha lōn takōt teukeudjōt rakan nam dròë — radja pindòë djisangka teuka dèëlat toeankoe djiteumèë lawan - djisangka rakan radja tjilaka

1100 radja kianòìh djisangka keunòë — rakan nam dròë djithèë hana njankeu sabab lōn peussingat - bès neubri ras jat tamòng lam goeha radja leungò meunan hareutòë - moeda samlakòë ban kheun gata djakalèë meunan moeda samlakòë — geutanjòë doea dròë tamòng lam goeha radja nasrani djitamòng sidròë — ka djeuët lhèë dròë tamòng lam goeha 1105 geutamòng peutrōih lam goeha njan — abeudōrahman neubatja doe'a 
neubatja doe'a hana khali — radja nasrani iëm dròe sadja al-hamdoe lillah alladi naddjakoem min Dakjünos doe'a radja teumanjòng $\mathrm{ba}^{5}$ oereuèng nam dròe - padoem oeròè sinòê gata ladoem djikheun jazcman aze baida jazmin ladoem djikheun djikata

1110 ladoem djikheun na si"oeròê — sikhan oeròe ladoem kata adat han si'soeròè sikhan oeròè - kamòè sinòe teungeut lam gocha radja neukheun narit meunòe - gata sinòè tréb ka lama lhèëreutōihsikoereuëng thōn lam goeha njan — teuma theuč njan teungeut indra gata pansan hana tathèè - meunan meuteumèè dalam tjalitra

1115 padoem radja la én meugantòe — radja pindoè tréb ka pahna nabi isa keuradjeuën di nanggròë - gata sinòë hana djaga nabi 'isa mès reuët ka tréb - barō oedéb gata lam goeha radja tanjòng oebas meuntròë - pakri djinòè geutanjoè tagisa sang na hadjat doem geutanjöe - tapoewòe djinòè doem oe tangga

1120 tamaba wòë djinòë sadjan - sit han djeuët han beuseureuta jōh masa njan meuntròë tanjòng - ba ${ }^{5}$ oereuëng njan dalam goeha pakri djinòë wahé teungkoe - peuë na nabsoe nibas radja neukheundas ${ }^{s}$ poewòë gata oe nanggròë — pakri djinòe djas oedéhta sit han djeuët han teungkoe neuwòe — ban toedjoh dròë sadjan radja

1125 oereuëng toedjōh dròë seusōt leugat - hana hadjat lōn keu tangga hana hadjat lōn keu nanggròè - bahkeu sinòè dalam goeha dèèlat toeankoe neuwòè djinòë - meưah keu kamòè doem barang na neulakèë doe'a toeankoe keu kamòë - beuteutab disinòe dalam goeha na sisat teuma doedòë - ban toedjōh dròe neubatja doéa

1130 minta $^{s}$ doe'a ban toedjōh dròë - meunòë boenjòë doem geukata seureuta geusangkat doea djaròë - ban toedjōh dròë siseun seureuta allāhoemmā bihakki ma arajtana min al-'adja'ibi fí anfoesinā alä kabad̦ta arwāhanā walam jattali' alainā ahadoen

ja toehankoe moepandang han lé — barang njang lahé ateuëh dōnja na bèskeu leumah lé njang 'adjajéb - kamòë bès tréb tatoeẻng njawa bè ${ }^{s}$ leumah lé kamòë toedjōh dròë — beuséb ngòn njòë ja rabana

1135 doe'a pi habéh njawòng pi gadòh - siseun ban toedjōh sigò pahna kata sahéb pò koerangan - radja jōh njan teubiët lam goeha radja éseulam ngòn radja kaphé - djiteubiët lé sadjan seureuta radja éseulam sabòh teumpat - sadjan $\mathrm{ra}^{s}$ jat balatantra

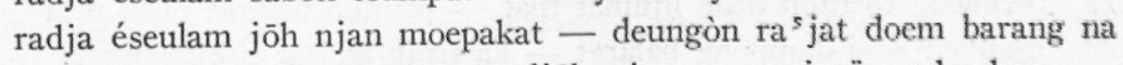

1140 neujoeë poemanòë oereuëng toedjōh njan - neujoeë peukaphan bandoem rata 'òh lheuëh manòë deungòn kaphan — oelama sadjan seumajang sigra 


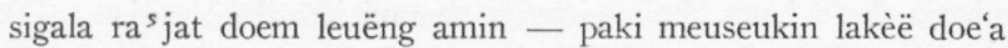
geusië keubeuë trōih meuribèë — radja meudjamèë diloea goeha geusië keubeuë keu kanoeri - sigala paki lakèë doe‘a

1145 toedjōh oeròë radja kanoeri - sadjan paki diloea goeha pintō goeha geutōb jōh njan - geulabō deungòn geula ${ }^{s}$ dama lheuëh njan radja tanjòng pakat — pakri mangat geutanjòë doemna pakri mangat geutanjòë djinòë - keureuna gòb njòë beuragama boemoepakat doem geutanjòë — patōt keu djinòë tabōh tanda

1150 sabòh meuseudjit patōt takeubah - teumpat diarah sòë na teuka meunankeu pakat radja éseulam — radja djahnam lasén bitjara radja nasrani djimeudjamèë — lasén lagèë di djih keunira radja nasrani kheun bès meunan — maté gòb njan agama hamba maté gòb njan agama oedéb - di kamòë pi wadjéb moebōh tanda

1155 patōt moepeugèt sabòh koebah - teumpat meukeubah patōng beurala meunankeu pakat radja nasrani - hana khali djibōh da ${ }^{5}$ wa doea radja hana moepakat - meukōseumat di babah goeha radja éseulam ngòn radja kaphé - meusasòë beudé $\mathrm{ra}^{s}$ jat that bha doea radja jōh njan meusoegang - hingga djeuët prang meuseunòh goeha

1160 keureuna goeha njan $\mathrm{ba}^{s}$ tjeuë nanggròë — ban doea dròë geukheun areuta radja éseulam ngòn radja kaphé — lheuëh beudé djeuët prang raja haba poeprangan sit ma ${ }^{5}$ loem lé - ladém maté barang hò na le alat poeprangan sit that ma ${ }^{s}$ loem - beudé meutoem lasén pi na piasan prang le that bagòë - masloem bas dròë doem peukara

1165 meung ka djeuët prang meuhat pantaï — talō siblah kòn ban doea meunang éseulam talō kaphé - hana sòë lé ngòn meuda ${ }^{5}$ wa geupeugèt meuseudjit teuma disinan - sipeureuti peureuman alah ta'ala lanattachidanna 'alaihim masdjidan - peureuman toehan njang peunjata saré maté radja nasrani - geupeugèt lé meuseudjit raja

1170 ba $^{\text {s }}$ koeboe tamlékha geupeudòng meuseudjit - oereuëng keumiët barang djan na nan tamlékha beuna tatoesòë - di roem nanggròë roemòh tangga meuseudjit roem poentja ${ }^{s} \mathrm{dji}$ intan — tamèh lapan sit raja-raja doemna oereuëng djas diarah $-\mathrm{ra}^{s}$ jat bahrōlah kajém teuka inòng agam djas peulheuëh $\mathrm{ka}^{s}{ }^{s} \mathrm{j}$ — asab moebōj-bōj barang djan na

1175 oereuëng toedjōh dròë kramat that — printah halarat èelia raja njankeu wali dampéng halarat - ka trōih hadjat sòë meunada oereuëng peulheuëh $\mathrm{ka}^{5} \mathrm{o} \mathrm{j}$ geunab oeròë — hantòm padòë geunab masa 'òh lheuëh maté oereuëng toedjōh dròë — asèë sinòë maté diloea iradat toehan meuleuha koedrat - asèë njan meuhat masōs tjeuroega 
1180 radja joeë tanòm jōh njan asèë — teumpat meuteuntèë diloea goeha diloea meuseudjit radja joeë tanòm - meunan moephōm bas tjalitra tamat kisah aseuhabōjkapi - tanjòng jahoedi asaj moela tanjòng jahoedi oebas 'ali - habéh neukheun kri doem peukara 'ali tanjòng jōh masa njan - njò bit meunan lam tèërit kata

1185 seus sōt jahoedi phōn beunalah - hana oebah ban kheun gata meutamòng djinòë agama moehamat — neulakèë rahmat keı kamòë doemna jōh njan jahoedi djis oetjab tjahdat - éleuham halarat dalam dada asjhadoe allā ilāha illāllāh zera asjhadoe anna moehammadan rasōeloe'llāh - jahoedi pantaïh masōs agama aseuhabōjkapi kisah le that - maséng riwajat doem oelama

1190 khileuëh bandoem oereuëng mòsmin - maséng jakin akan rabana maséng takoea keu pòteu alah - maséng peugah doem oelama 'òh nòë kisah aseuhabōj kapi - neutanjòng kri ba ${ }^{s}$ oelama aseuhabōj kapi oereuëng toedjōh - baranggasòe trōh djaras ${ }^{5}$ baja oereuëng toedjōh lapan ngòn asèë - lōn bōh hé sampèë sinòë doéa

1195 tamlékha makeusalémina mareutoenih noenoenih sareuboenih dawōnoeanisoe paliaseutatioenih kateumi waboedoeh la élaha élalah moehamadan rasoelōlah ja aboebaka ja 'oema ja ōseuman ja 'ali ja djébrasi ja mikas ${ }^{s}$ ja ésrapi ja 'èdra ${ }^{s} i$

1200 tamat soerat oeròë sabtoe - watèë teungkoe teungòh leuhō kheuët hana gèt wahé sahbat - lōn seumoerat hana biasa doeablaïh oeròë boeleuën dōjkasidah — habéh soedah tamat haba hadjarat siribèëlhèëreutōïhdoeaplōhsikoereuëng - meunan geukheun lam tjalitra

njòë lōn peugah teumpat soerat - na tatoepat oelōn rika

1205 matang keupoela ri blang awé - teungkoe ali njang meurika meung na nabsoe lakèë $\mathrm{si}^{s}$ at - keunòë ta ${ }^{s}$ euntat hé tjèëdara tamat soerat wahé adòë — rab tjòt oeròë habéh haba tammat amīn ja rabba'l-'ālamīn - tammat kalām amīn 
TEKST B.

(De cijfers voor de verzen duiden aan, dat deze overeenstemmen met de gelijk genummerde verzen van $\mathrm{A}$. Uit de nummering kan ook blijken welke verzen uit $\mathrm{A}$ in $\mathrm{B}$ worden gemist. Verzen van $\mathrm{B}$ die in A geen equivalent vinden, zijn aangegeven met drie stippels.)

Béseumélahirahmanirahim - toedjōh isim sangat meulia ébeunoe 'abaïh njang pò riwajat - djeuët keu oebat tamsé peunawa sabda nabi 'alòjhé salam — toedjōh isim neujoeë adja neujoeë peuroenòë keu kanas kana $^{s}$ - nameung djaras mara baja

5 tjèëtan la'in han djipeurab - sabab beureukat nama èëlia antara 'isa deungòn pangoelèë — oereuëng njang dilèë sabòh masa dalam tapeusé njan teuseuboet - nama sipheuët sinan njata soeratōjkapi $\mathrm{ba}^{\text {s }}$ djoeïh sōbeuhan — sinan tèèlan lahé njata padoem-padoem ajat koeroe ${ }^{s}$ an — adjaran toehan keu sòjdina

10 oereuëng toedjōh dròë lapan ngòn asèë — sit meuteuntèë kalam rabana aseuhabōjkapi sit ban toedjōh — barangsòë trōh moebagia djakalèë tasoerat dibas roemòh — peunjakét gadòh njang ampoenja lagi roemòh pi han toetōng - toehan toelōng nibas bala lagi pantjoeri han djipeurab - deungòn beureukat nama èëlia

15 raseuki pi moedah sòë njang 'amaj — karōnja toehan teuka areuta djakalèë tasoerat dibas bidōs $^{s}$ - tan lé doedōs ${ }^{s}$ barangdjan masa han lé karam baja la ${ }^{s}$ ot - teuka ribōt badè raja djaras $^{\text {s }}$ toepheuën djis ōh hantoe - beureukat teungkoe asòë goeha

20 aneus miët mòë njang that kajém - tasoerat isim toedjōh nama njan tasoerat $\mathrm{ba}^{s}$ keureutaï - teuma takeubah $\mathrm{ba}^{\mathrm{s}}$ koepala

22 adat han takeubah dalam bantaj - han lé djimòë teungeut mata

25 oereuëng njang meugòë na gèt padé - tasoerat lé nama meulia tasoerat $\mathrm{ba}^{5}$ kajëë harah beukeunòng - diteungòh oemòng njan tapoela sigala peunjakét han lé keunòng - tikōïh geusòng han lé teuka oebat moemang pi sit djeuët that - njan tasoerat bas keunòng koetika teuma $\mathrm{ta}^{s}$ ikat $\mathrm{ba}^{s}$ aweuës - djaròë oeneun kòn wië gata

30 moemang pi gadòh hé sahbat - deungòn beureukat toedjōh èëlia 31 oereuëng meusaneus soekaran that - soerat tasikat bas oeram pha $33 \mathrm{ba}^{s}$ pha oeneun njan tas ${ }^{\text {sikat }}$ - toelōng halarat boedas keuloea 35 seulamat boedas deungòn iboe - toelōng toehankoe beureukat èëlia 
36 beukit tatamòng ba ${ }^{s}$ peuhoekōman - tamè sadjan soerat meulia

$38 \mathrm{ba}^{5}$ sapaj oeneun njan ta sikat - meunang meuhat keunòng ngòn $\mathrm{da}^{5}$ wa

41 djakalèë $\mathrm{ba}^{5}$ radja gata salah - keunòng amarah ateuëh gata meungka tadjas ${ }^{5}$ tamè sadjan — ampōn meuhat han lé meureuka akaj peunòh sòë njang soerat - leubèh pangkat lagi kaja djakalèë djingoej oelé inòng madeuëng - han lé boerōng keunan teuka

45 han lé teuka ōmi sébeujan - meuteumeung meunan dalam sabda

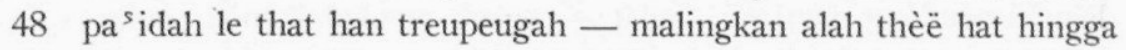

49 sit beutatrōh sabòh sapò - hé adòë pò doemteu rata

51 djakalèë han djeuët dròë bas gòb tajoeë - meung han pakri meuteumèë laba

53 bès tatjhén-tjhén keu neuroegòë - alah gantòë ngòn sababnja

54 deungòn sabab soerat hikajat - neubri beureukat $\mathrm{ba}^{\mathrm{s}}$ areuta

56 raseuki moedah baja gadòh - sit beutatrōh doemteu rata

58 sōbeuhanalah meuhasoetji - toehan njang bri gata meulia

60 sōbeuhanalah waleuhamdoelélah - djinòë lōn kisah haba èèlia meuhasoetji pòkoe toehan — njòè koerangan phōn lōn moela oelōn soerat lōn peuteuntèë - lōn toeëng teuradjèë ba ${ }^{s}$ oelama oelōn peu ${ }^{s}$ atjèh tapeusé koeroe ${ }^{s}$ an - harab keu toehan ampōn dèësa soepaja moephōm bas njang doengèë - beureukat pangoelèë nabi kita

65 deungòn mò ${ }^{s}$ djidat pangoelèë nabi - keu lōn toehan bri iman sampōna kalam toehan $\mathrm{ba}^{s}$ lōn seus ōn - hingga adjaj lōn ilang njawa deungòn beureukat kalamōlah - la élaha élalah ba $^{s}$ lōn kata

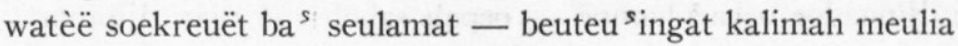
deungòn beureukat ajat koeroe ${ }^{s}$ an - peureuman toehan nịang that meulia 70 peureuman alah sabòh ajat - njòë lōn soerat sabòh bandja kalalahoe ta'ala - am hasébeuta anna aseuhaban kahpi warakimi kanoe mèn ajatina 'adjaba

... kata siah aboe moehamat - leungò hé sahbat doemteu rata

71 neuleungò nibas "òjnòn na im $-\mathrm{ma}^{s}$ na rakim neutjalitra lhèë dròë oereuëng wèh di gampōng - $\mathrm{dja}^{s}$ lam goenòng meudiwana teukeudirōlah meuleuha koedrat - njeum rōt langèt ateuëh koepala ban djikalòn laloe djiploeëng - teuma meuteumeung sabòh goeha

75 goeha batèë sangat indah — djitamòng pantaih sigra-sigra 'òhsaré trōih djih oedalam — rōt lé meugam pintō goeha

77 teutōb goeha deungòn batèë - pakri lagèë rèt keuloea

79 baranggari han és ilah - meung kòn bas alah njan tapinta

80 peuë na 'amaj neutrimòng - sinòë tatoeëng djinòë pahla talakèë beuleupaïh lam dōnja njòë - beulheuëh geutanjòë dalam goeha tjoeba ingat hé teungkoe - njan tangadoe $\mathrm{ba}^{s}$ rabana

Deel 98. 
kri tjit narit di oereuëng sidròë — tangò djinòë lōn peuhaba di lōn pi na 'amaj sabòh - masa djandéh lōn keureudja

85 bas peunjeum lōn mòseutadjabah - djinòë lōn peugah bas rabana lōn peussoepah gòb bas poeboeët 'amaj - lōn bri beukaj ngòn blandja

87 ban njang mas'loem lōn peu ${ }^{s}$ oepah - lōn peusadat barangdjan masa

89 lheuëh njan teuma teuka sidròë — oereuëng lakòë njang that takoea

90 lagi dahét amat sangat - roepa djròh that hana tara

91 kamòë peudòng meujoeë ibadat - oepah meuhat kamòë peuna

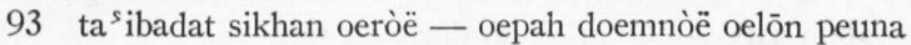
sadoem oepah ngòn njang sis oeròë — tadòng sinòë moeda balia

95 lheuëh njan djidòng teuma sinan — poedjòë toehan hana reuda djipoeboeët 'amaj sikhan oeròë — djilakèë dròë njan djiboengka lōn bri oepah ban njang djandji — djiboengka lé sigra-sigra oereuëng njang dilèë teuma seumoedi - padoemna geubri keu moeda balia teuma djipeugah ban njang koebri - beungèh paki njang peutama

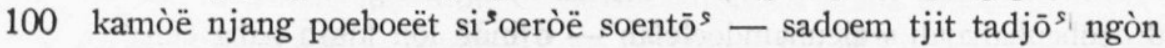
moeda balia

jōh njan beungèh boekòn boebarang - han djitém toeëng ka djiboengka tinggaj oepah djih djibòïh dròë — soesah kamòë hana tara oepah njang tinggaj lōn blòë leumò — oeseuha kamòë moeplara djimeusaneus hana teudōh - hingga tōs plōh hana reuda

105 padoem lawét teuma doedòë - oereuëng sabòh ròë lòm ka teuka oemoe toeha sangat la'èh - that ka leutéh doem angèeta

107 laloe djingadoe oeba' kamòë — oepah sabòh ròë njan djipinta

109 lōn peutoenjòs lé ngòn oepah — leumò bahrōlah njan di gata

110 teuma djikheun lōn poewajang - hana sajang 1j̄n peuhaba

111 oelōn meusoempah walah bélah — sahbat njò sah milés gata

113 teuma djitoeëng habéh bandoem - ngòn rilasan até soeka

114 njankeu 'amaj lōn hé rakan - djinòë bas toehan lōn toeëng pahla

116 ja ilahi wa ja rabi - keu lōn tabri djalan keuloea djakalèë njò 'amaj ngòn keureuna alah — toehankoe peuleupaïh nibas $^{s}$ goeha

118 kalam pi rōt njan di babah - goenòng pi tjrah njan sikada

120 barō leumah tjahja oeròë — tjoeba hé adòë djinòë di gata kri tjit narit teuma njang las én — di lōn pi kaman bah lōn tjoeba

122 di lōn pi na jōh sabòh ròë - boeëtan kamòë masa moeda

125 oereuëng binòë teuka ba ${ }^{s}$ lōn — njan djimeuhòn peuë halé na

132 roepa sambinòë that gèt lakoe - meunjeum na nabsoe teuka hawa

133 laloe meukheun $b^{s}$ oereuëng binòë — tangò kamòë pò djròh roepa

135 di lōn keu gata até lōn that - peuë njang hadjat pi lōn peuna 
meung tapeutrōih hadjat kamòë - baranggapeuë pi lōn peuna ban djileungò lōn kheun meunan - taprèh toean sikléb mata lōn $\mathrm{dja}^{5}$ tanjòng $\mathrm{ba}^{5}$ soeami - meungka neubri oelōn teuka dja ${ }^{5}$ keu tawòë pò sambinòë — beureudjang djinòe njan tateuka

'òh saré tō ${ }^{s} \mathrm{ba}^{5}$ soeami - djitanjòng lé sigra-sigra habéh djipeugah ban njang meukeusoet - laloe djiseus ${ }^{s}$ tt han meungapa ban njang djilakèë bahlé tabri — asaj bès maté aneus tjoet raja lheuëh njan djidjas oereuëng binòë — djandji boenòë kamòë rila ada ${ }^{s}$ meunan hé oereuëng binòë - ta $^{s} \mathrm{é}^{s}$ keunòë njan beusigra

145 'òh saré rab oelōnteu keunan - djibòih peukajan bas angèëta djibòih idja leumah 'èërat — oelōnteu peurab sigra-sigra 'òh saré rab oelōnteu keunan — jòkeu badandji ban geumpa laloe lōn tanjòng bas oereuëng binòë — pakòn meunòë jò angèèta teuma djidjaweuëb leumah leumbōt - sabab lōn takōt keu rabana sabab lōn takōt njan keu toehan - leungè badan misé geumpa ban lōn leungò meunan djipeugah - di lōn pi soesah hana tara la'èhkeu toebōh teumakōt até - lōn tanjòng lé oeba ${ }^{5}$ nisa pakri tatakōt njan keu toehan - keusoekaran han takira

165 lōn bri seudeukah kan oereuëng binòe - teuma djiwòè tinggaj hamba njankeu 'amaj ka lōn peugah - djakalèè ékeulaih leumah tanda ja toehankoe tabri djalan - beuleupaïh lōn nilam goeha

169 djikheun pi lheuëh goenòng pi beukah — kakeu leumah tjahja adara

170 kakeu leumah mata oeròë - kakeu sampòè sigala dōnja 172 han tjit na djeuët lòm djiteubiët - teuma marit njang keutiga

174 di lōn pi na jōh sabòh ròë — jakin kamòë keu nang apa

175 ma lōn ngòn doe toehaneu that - lōn hareukat hana tara lōn goebeuë kamèng lōn toeëng oepah — kan napakah dròëneu doea

177 geunab seupōt lōn mè ië abin - kan minòman iboe bapa

$179 \mathrm{ba}^{\text {s }}$ si soeròë teukeudi toehan - teuka oedjeuën trōïh an sindja

180 oeròè pi seupōt oelōnteu wòë — han doea dròë teungeut njidra

181 ngòn ië abin njan di djaròë - meudòng sidròë moeprèh djaga

183 niphōn sindja hingga soebòh - hana sabòh pi na djaga

184 até lōn goendah boekòn boebarang - tjawan lōn tatang trōih an padja

186 'òh djaga ma nibas pansan - lōn $\mathrm{djo}^{5}$ tjawan lōn keuloea

204 njankeu 'amaj ka lōn peugah — djakalèë ékeulaïh leumah tanda

205 ja toehankoe tabri djalan - beuleupaïh lōn nilam goeha

207 kalam pi habéh goenòng pi teuhah - ka leupaih teubiët ban tiga

208 kakeu theuëh teubiët ban lhèë - meunan lagèë sabòh tjalitra

... njan riwajat ébeunoe 'oema - meunan neungò bas sòjdina

210 ébeunoe 'abaih le riwajat - leungò hé sahbat doemteu rata 
... masna rakim neukheun wadi - iseuhabōjkapi neukheun disana

... sa'at ébeunoe doebé sabòh riwajat - hana moepakat neutjalitra

$211 \mathrm{ma}^{5}$ na rakim ban lòh batèë — meunan lagèë sabòh haba aseuhabōjkapi sinan teusoerat — geutrōh meuhat ba ${ }^{s}$ pintō goeha lòh njan geubōh dalam peutòë — meunan adòë neutjalitra sōbeuhan alah meuhasoetji — aseuhabōjkapi lōn tjalitra

215 antara 'isa ngòn pangoelèë - meunan meuteumèë dalam sabda aseuhabōjtèërit pò riwajat - teuleungò ba' sahbat sòjdina 'oema

217 ba $^{s}$ si $^{s}$ oeròë thèë dròë jahoedi — datang keumari oebas 'oema

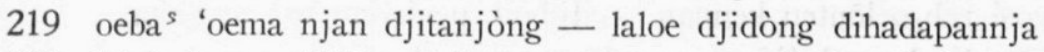

221 hé ja 'oema dilikōt moehamat — gata meugah that lagi radja

223 meukeunda $^{s}$ tanjòng sabòh masasalah - beutapeugah ngòn sō sama meung djeuët tapeugah njang meutanjòng - njò bit reumbang agama gata 225 nabi moehamat njò bit nabi - han meus oengki kamòë njang na laman han djeuët njan tapeugah — njò bit han sah agama gata nabi moehamat njò boekòn rasoej - njò meureuroej tipèë daja ban 'oema ngò soe ${ }^{s}$ euë jahoedi - neudjaweuëb lé pantaïh sigra han peuë katanjòng hé jahoedi - toelōng rabi djaweuëb hamba

230 na taleungò wahé sòjdi - langèt peuë goentji ngòn peuë boeka

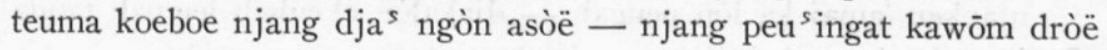

kòn manoesia

232 kòn nibas ${ }^{s}$ djén wahé sòjdi — teuma lagi na lòm 'lōn tanja

234 njang ateuëh boemòë teuma na sidròë - hana djikandōng oelé boenda

235 manòs koekoeës peuë djipeugah - hih-hih paraï peuë kheun goeda

236 tjanggoeës peuë djikheun sana-sini - mirahpati peuë djikata njankeu soe ${ }^{s}$ euë dilèè silapéh — peugah beuhabéh hé sòjdina sòjdina 'oema toendō ${ }^{s}$ oelèë - meunjeum malèë ba $^{s}$ panita

239 neutoendōs oelèë djab oe boemòë - seureuta neumòë njan neukata

$240 \mathrm{ba}^{s}$ han moepeugah pi han meulagèe - han tōs èleumèë neukheun hana

241 laloe djibeudòih panita jahoedi - ma djikheun lé haba njang ka atjeuhadoe $^{s}$ anna moehammadan lam jakōn ambia wa ${ }^{s}$ anna dina ésculami batilon - meunan djikheun sabét beuna

247 lheuëh njan marit salman parisi - hé jahoedi leungò hamba

248 piōh sis at hé jahoedi - sòjdina 'ali djéh ka teuka

250 'òh sadjan trōïh aboehasan - 'oema jōh njan até soeka

252 geumeutjōm-tjōm sabé 'èdat - até mangat sòjdina 'oema

$\ldots$ teuma neupeugah oeba ${ }^{s}$ 'ali - tanjòng jahoedi oeba ${ }^{\text {s }}$ 'oema

253 sòjdina 'oema neu'sisarah - tjoeba peugah peuë djipinta

256 hé jahoedi tanjòng djinòë - baranggapeuë heundas gata

258 rasoelōlah neupoebeuët kamòë - baranggapeuë èleumèë na 
...

siribèë pintō nibas èleumèë - la ${ }^{5}$ én teuma lòm meuganda $b^{5}{ }^{5}$ sabòh pintō lòm siribèë - meunan èleumèë niba ${ }^{5}$ hamba teutapi na djandji kamòë - tangò djinòë hé panita tatém éseulam adas moepeugah - beukeuhan salah meutjalitra pròë haj sabét ban lam tèërit - njankeu sarat djandji hamba seu ${ }^{5}$ ōt jahoedi djikheun na'am - han peuë meutém ban kheun gata lheuëh njan djitanjòng seun-seun sabòh - 'ali peugah ngòn so $\overline{0}^{s}$ sama teutapi ngòn mós djidat nabi - tanjòng jahoedi njang peutama pintō langèt peuë keu goentji - djaweuëb 'ali neukheun tjeuroega moetjrés bélah njankeu goentji - hé jahoedi la ${ }^{s}$ én hana oereuëng njang moetjrés 'amaj han lé - laloe teutōb lé pintō doemna aneu $^{5}$ goentji teuma tjahdat - langèt meuhat ngòn njan teuboeka sabab 'amaj oereuëng éseulam - tòh lòm la ${ }^{5}$ én tanjòng landja koeboe njang djas deungòn asòë - peugah keu kamòë hé sòjdina njan ikan hoet njang 'oeët joenòih — djiba ban sabòh $1 a^{s}$ ōt raja njankeu koeboe njang dja ${ }^{5}$ ngòn asòë — la én peuë djinòë tanjòng landja teuma na sidròë proenòë kawōm — boekòn djeunèh djén manoesia njankeu sidòm nabi soelòjman - nameulah geubōh nan hé panita njan ka habéh hé jahoedi - tanjòng lagi doem njang hawa limòng peukara njang lōn tanjòng - njang han djikandōng oelé boenda njang han meugah dalam areuham - njang phōn adam éntoe kita keudoea oenta nabi salèh - keulhèë kibaïh ébeurahima keupeuët sidòm nabi soelòjman - binatang lhèë njan asòë tjeuroega njang limòng njan na tatoesòe - nini geutanjòë toeanteu hawa njan ka habéh na lòm la ${ }^{5}$ én - tanjòng reudjang hé panita manòs $^{s}$ koekoeës $^{s}$ oeròë malam - peuë djikheun njan hé mèëlana ōdeukoerōlah ja rapilin — peusingat énsan sòë njang loepa hihi goeda njan peuë djikheun - djaweuëb djoendjōngan neutjalitra alahōmansō 'ibadahōn mòsminin 'alan kapirin doe'a keu mòs ${ }^{s}$ in barangdjan masa boemeunang mòs min beutalō kaphé - djan meuhihi meusoeara di mirahpati djikheun jahoehoe - njan hé teungkoe salèh peuë ma na njan djiseurapa oereuëng toeëng wasé -- njang toeëng adat glé oesō koeala

alahōma la'ina 'atjarahoe - ja toehankoe tabri la $a^{5}$ nat' ateuëh oereuëng toeëng adat glé ngòn oesō koeala tjanggoeës $^{s}$ meusoeara kiam boenjòë - di djihnjan peuë salèh haba moetjab teuseubèh poedjòë rabi - han teungeut lé malam djoela soelōïh njang akhé bandoem djibeudòih - hana sabòh njang han djaga sōbeuhanalah rabénmas boet - njan djiseubōt bandoem rata 
342 jōhnjan jahoedi mangat até - moetjab lé kalimah doea

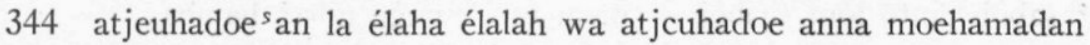
'abeudoehoe wa rasoeloehoe - doedòë teungkoe masōs tjeuroega

345 njang sidròë treu ${ }^{s}$ teuma rakan — ka lōn meusiman misé di gata

346 habéh bandoem djiśéseulam - trōn éleuham dalam dada

353 na sabòh treus masasalah - djinòë tapeugah hé mèëlana

357 oereuëng djameun geukheun toedjōh dròë - han meutoesòë

358 hhèëreutōïhsikoereuëng thōn gòbnjan ka maté - teuma oedéb lé misé njang ka nanggròëgeu pat namageu sòë - dilèë doedòë neutjalitra

360 asèë sabòh geukheun sadjan - salèh peuë nan pakri roepa

363 goenòngdji peuë goehadji peuë nan - doem sikeulian neutjalitra

365 laloe meusabda sòjdina 'ali - sabda nabi neupeuhaba

367 na teuseuboet dalam koeroe ${ }^{s}$ an - sipheuët gòbnjan ban sineuna aseuhabōjkapi ban toedjōh dròë — di roem nanggròë asaj moela mideuën akeusoeïh nan kariah - djahéliah njang bōh nama

370 oereuëng éseulam tan teuseuboet - meunan mas roeih dalam tjalitra lajeuë keuradjeuën malés salèh — além pi leubèh ngòn war'a

372

374

375

376

379

381 ban djikalòn leumah peutò - doea djaròë lé djiboeka

384

393

395 "èbeuraniah basa kitab - basa soerat nabi moesa

'òh maté njan la ${ }^{s}$ én meugantòë — radja pindòë tan agama di kianòih radja parisi — djimeus oengki keu agama

djigoebeuë kamèng djihnjan dilèë — hana sòë thèë djeuët keu radja teukeudirōlah $\mathrm{ba}^{s} \mathrm{si}^{s}$ oeròë — djidoeës sidròë joeb kajèë raja djis eu didalam doem keureutaïh - laloe djiplòih djipeunjata djis eu soerat misé kitab - kheuët pi djròh that hana tara

4 lheuëh njan djimè oe meunasah - toean siah djijoeë batja siah njan teuseuboet oemoe djameun - toedjōhreutōinh thōn bas toean siah neubeuët phōn-phōn - radja karōn pò areuta

haba lam soerat sit ka ma ${ }^{s}$ loem - meuih djitanòm doeablaïh teulaga

tjalitra kri tjit narit di kianòih - takheun beudeuïh hé mèëlana tapeugah pat oelōn djas $^{s}$ toeëng - tamoeboeloeëng bagi doea siah neupeugah lé ngòn teumpat - atédji mangat hana tara djilakèë lham ba ${ }^{s}$ oereuëng binòë — djidjas ${ }^{s}$ koeëh djinòë koerè ${ }^{s}$ teulaga kianòïh djas pantaih-pantaïh - seun sreut leumah oereuëng toeha teudòng di rèt na misé siah - badjèë djoebah seureuban raja 
420 hé kianòïh kadòng dilèë - kaleungò nibas kèë sabòh bitjara.

422 kapòh siah tjit dilèë boematé - areuta han lé bagi doea

424 ban djileungò iblih peugah - doem geukeubah dalam dada

425 gèt koedjas ${ }^{s}$ pòh siah njan dilèë - koetoeëng keu kèë doem areuta laloe djiwòë oe meunasah - teungkoe siah djidjas mita teuma meuteumeung teungkoe siah - peudeuëng pantaih djikeuloea siah neukheun hé kianòih - lōn bès tapòh tasinanja

429 tapeu $^{s}$ oedéb lōn bès maté - areuta bahlé toeëng keu gata 432 han djipeungò narit siah - djitjang pantaih teuma pahna

438 djidjas ${ }^{s}$ koeëh meuih ban njang nabsoe - hingga meuseuhoe trōih ba ${ }^{5}$ radja 439 siteungòh meuïh keu radja djibri - nabès maté geupòh bila

441 teuma radja bri mideuën akeusoeih - sabab le meuïh djibri keu radja

443 sinankeu teutab keudiaman - akhé daman djeuët keu radja areuta le that rakan seureulòe - djiprang nanggròë hana tara seun-seun sigampōng seun-seun sinanggròè - teuma doedòë djiprang radja

... talō radja djitoeëng poetròë - djihnjan sidròë that goeranta

448 teutab djitoeëng banda ngòn nanggròë - djipeugèt meuligòë sabòh that raja

djeunèh nibas pira $^{s}$ teus oepam - loeaïh dalam siteuntang mata 450 loeaih dalam sabòh peureusah - hantòm peureunah dilèë njang ka ... namribèë haïh sabòh peuretusah - getılabō meuih ban silingka ... lingka meuligòë doem kandé meuïh - tjahja peungeuïh hana tara 454 geunab malam kandé geutōt - hantòm seupōt barangdjan masa 459 minjeu $^{\text {s }}$ dòjtoen doem lam kandé — radja djahé bòih areuta 460 dalam meuligòë keuta that indah - meuih meutatah intan pi na di wië di oeneun kroesi meuih - na lapanplōh bas ${ }^{s}$ keukira

... djipeudoeës $\mathrm{di}^{s}$ ateuëh doem oelè̈balang - doem sibarang njang raja-raja

465 bandoem di oelèë koelahkama meuih - tjahja peungeuih intan pi na koelahkama njan sikoereuëng sagòe - ban mata oeròë limpah tjahja

467 djipeungoej limòngplōh teuma aneu ${ }^{s}$ miët - roepa gèt-gèt aneus ${ }^{s}$ béntara

469 djibri peukajan indah-indah - badjèë mirah bandoem rata

471 siloeeuë idjō bandoem djròh that - di djaròë toengkat doemdji rata

473 djireugam toengkat meuih doem di djaròë - teuma nam dròë aneu ${ }^{\text {s }}$ oelama

474 njang nam dròë njan djibōh keu wadi - radja kaphé le bitjara

482 watèë djidoeës radja sinan - koenangan nam sadjan seureuta

491 lhèè di oeneun di wië pi thèë dròë — roepa samlakòë moeda balia

... roepa ilōs boekòn boebarang - ngòn peukajan djròh that roepa mata djròh that hana lawan - na doem bintang peungeuih tjahja boelèë mata pi that leubat - gigòë djròh that hana tara 
492 njan di oeneun tjitjém djimat - meunan adat barangdjan masa

494 tjitjémdji oetōïh teungòh ragòë — djipeuroenòë ka djisadja

493 teuma njang di wië djimat peunoeman — didalam njan kleumbas djeumpa

498 mawò ngòn ata sabòh peunoeman — njan bèë-bèëwan neungoej radja

500 peunoeman meuih meuteurapan - djeunèh intan poedòë meutia 'òh djipeulheuëh tjitjém di djaròë — tjitjém ragòë goena biasa djipò meuhat dalam peunoeman — dilèë tjitjém njan maséng djeumba

507 hingga rata boelèëdji basah — teuma djiminah ateuëh radja teuma djikeupō lé ngòn sajeuëb - ië teupeureutjés ateuëh radja meuhambō ië 'òh leungò boelèë — meuhajas bèë gahroe tjeunana

509 lheuëh njan tjitjém maséng djiwòë — oebas djaròë njang ampoenja 511 njandoem nè ${ }^{s}$ mat radja la ${ }^{s}$ nat - meugahdji that ateuëh dōnja

525 meuih pi le that radja meuleu'oen — misé karōn njang that kaja

527 misé nameuroet njan deungòn 'at - sit that la ${ }^{s}$ nat darōhaka

529 han tjit sabé ngòn kianòï — djihnjan oetōï le bitjara

530 padoem lawét njang moemeunan — teutab'keuradjeuën si tjilaka

531 hantòm sakét pi meung oelèë — hantòm lajèë pi ië moeka

533 bah meung moemang pi sit tantòm — that paléh sōm radja tjilaka

534 hantòm timòh toemoeët ngòn koedé — radja kaphé asòë noeraka

532 bah meung batōs djih sit tantòm - mas siët keu toehan radja tjilaka

535 laloe djikheun dròëdji toehan — kaphé djahnam darōhaka djikrah rasjat bandoem nanggròë — djijoeë seumah dròë radja tjilaka sòë njang patéh djih njò toehan — djibri peukajan ngòn areuta sòë njang meusoengki djipòh maté — that keu djahé si tjilaka oemoe lhèëplōh thōn teutab keuradjeuën - hantòm na mareuën

keu djih teuka

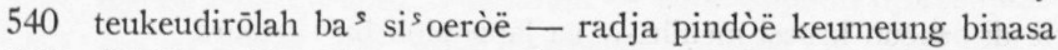

547 sidròë wadi peudana meuntròë — toean njan tòë that ngòn radja

548 djipeuhaba bas kianòih — ateuëh keuta meuïh djidoeës radja $^{s}$

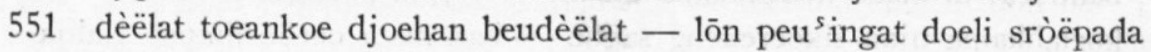
djikheun djipòh laseuka radja parisi — that djideungki keu sròëpada

553 djikheun djipòh toeankoe boematé - djikheun kaphé toeankoe gata

557 ban radja ngò narit moemeunan — soesah jōhnjan até lam dada poetjat ngòn moeka jò ngòn badan — srōt lé jōhnjan ateuëh keuta

559 koelahkama srōt diba $^{s}$ oelèë — radja lajèë ngòn ië moeka

564 tangò lōn peugah oereuëng njang nam dròë — njang samlakòë

koenangan radja

566 njang phōn tamlékha njan geupeunan - njang doea njan makeusajmina

568 teuma njang lhèë mareutoeanòih - meunan teungkoe geutjalitra

569 aseuhabōjjamin teudòng di oeneun — baranggadjan ngadab radja 
... njang dòng di wië njan pi lhèë dròë — taleungò sòë lōn kheun nama

570 noenoenòih ngòn sireuboenòïh - njang keulhèë teungkoe las én nama

571 paleujaseutatioenisoe njan geupeunan — njang lhèë dròë njan di wië radja

.... djidòng ngadab ba ${ }^{s}$ kianòih - ateuëh keuta meuïh teudoeës radja

578 koenangan kalòn radja goendah — djis eu oebah ngòn ië moeka

579 jōhnjan tamlékha ka teupiké — dalam até djikira-kira

585 djakalèe radja njan njòkeu toehan — pakòn sa ngòn manoesia njò radja njan boekòn toehan — sa ngòn énsan doem peukara

586 makeuën minòm ban di tanjòë - sa śé bandoem peuë hana bida

588 sipheuët toehan njeum kòn meunan - teutapi han njan djikata

591 oeròë malam sit djipiké — soesah até hana tara

592 makeuën pi tan tidō pi han - teumanjòng rakan teuma njang lima

594 hé tamlékha pakòn boe goendah - njan tapeugah oebas hamba

595 geutanjòë nam hoekōm sabòh — peugah adòë djròh peuë keureuna teuma seuneusōt moeda samlakòë — teupiké keudròë hé tjèëdara teupiké keulangèt njan di manjang - meugantoeng pi tan tamèh pi hana pat meugantceng han srōt keunòë — mata oeròë njan sòë poeba sòë hoeë boeleuën sòë bōh bintang — peungeuih bandrang keunòë tjahja

600 boemòë teuleuëng di ateuëh las ōt - pakri han hanjòt boekét njang na

604 teuma teupiké oedjoet dilōn - sòë soeẹt lam kandōng ajah boenda

605 jōh boenténg lōn lam proeët iboe - panè keu lōn boe sòë plara

609 sadjan lōn piké doem habéh deuïh - kòn kianòih njang plara

610 djih pi saban ngòn geutanjòë — pakri djinòë tòh bitjara

613 djihnjan kaphé la natélah — bés tapatéh hé tjèëdara

618 ban djileungò tamlékha peugah — doem geukeubah dalam dada

620 sabét beuna ban tapeugah - djipeuseumah ba ${ }^{s}$ tamlékha

621 ba $^{s}$ kamòë njòë bitjara tan — ban njang takheun meuseureuta

623 meung tas ikōt radja las nat - geutanjòë sisat asòë noeraka

626 tamlékha kheun ba $^{s}$ kapilah - hana ilah meung kòn taboengka

634 tawèh niba ${ }^{s}$ radja tjèëtan — poelang $\mathrm{ba}^{s}$ toehan alahōsama

635 toehan njang peudjeuët langèt boemòë - keunan geutanjòë hé tjèëdara

636 meunan moepakat oereuëng nam dròë - oedéh geutanjòé tadjas boengka

638 tamlékha poeblòë kajèë sibas - keu pangkaj neudjas las én hana

639 lhèë bòh deureuham nanggròë akeusoeïh — tjab kianòih di ateuëhnja

642 deureuham pi trōih dalam djaròë — beudòih samlakòë pasang goeda

644 peugèt peulana bōh ngòn keukang - teubiët oe blang doem meusapa

... djiteubiët blang tamòng gampōng — habéh djoerōng trōih oeloea

... nakeu lhèë mèn djaras di mideuën - doem sikeulian ateuëh goeda

648 kri tjit narit oereuëng sidròë - bè ${ }^{s}$ lé adòë tagidoeë ${ }^{s}$ goeda tabòih goeda tadjas ngòn tapa ${ }^{s}$ - bès lé galas keu areuta 
650 geutrōn tjōng goeda geudjas ngòn gaki - malam dan hari hana reuda

652 toedjōhplōh peureusah dji $^{s}$ ōh geudjas - beusōt tapas darah keuloea sabab hantòm peudjalanan - ngòn sabab njan djeuët binasa ngòn teukeudi toehan gaséh halarat - meuteumeung sahbat

teungò meusapa

655 meuteumèë teuma sidròë rakan - teukeudi toehan sangat kaja oereuëng toeëng oepah goebeuë kamèng - até hanèng soetji sapha

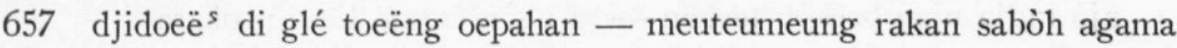

659 asalamoe 'alòjkōm dalém meutoeah — kamòë that grah lapa dahga

661 peuë na makanan ngòn minòman - kamòë rakan djis ōh sapa teuka seuneus ōt rakan oereuëng goebeuë — na bas kamòë hé tjèëdara

663 na makanan ngòn minòman — ië abin ngòn djabét keureuma

669 teutapi lōn kalòn keulakoean - gata toean rakan radja

672 peukajan le doem njang di asòë — salèh hò nanggròë takeumeung boengka salèh peuë sabab tabòih keuradjeuën — peuë reuën-mareuën teuka baja

675 peugah ba ${ }^{s}$ kamòë adòë meutoeah - takheun beusah ngòn sōs sama

... lheuëh makanan ngòn minòman - tangòkeu toean sabab meuboengka

678 kamòë njòë njò rakan radja kianòih - njò bit koesoeih koenangan radja

679 njang djeuët moewèh njan di nanggròë — radja kamòë tan agama

681 radja kaphé asòë djahnam.- dròëdji toehan njan djikata

684 djijoeë seumah oeba ${ }^{s}$ kamòë — aneus bisòë that tjilaka

685 njankeu sabab moewèh di nanggròë — njang trōïh keunòë oebas gata djinòë han meudoeës lé digampōng — bahlé lam goenòng meudjas tapa 687 adas njò moemeunan wahé adòë — kamòë sidròë sadjan gata

690 di lōn pi han lé koedòng di nanggròë — akhé doedòë djeuët binasa

692 sòë boe nama dalém teungkoe dròë — sira nan geuhej dalém radja

694 nama kamòë doenoeanòï - meunan mas roeỉh doem oelama

695 djinòë lōn djas taprèh sis at - lōn djas ${ }^{s}$ euntat kamèng tjèëdara lōn djas poelang kamèng rakan - lōn pi sadjan teuma ngòn gata teuma djidjas reudjang-reudjang - trōïh lé jōhnjan sigra-sigra djinòë kamèng oelōn poelang — djinòë oelōn toean keundas boengka

699 kamèng poelang oepah djilakèë — habéh meuteuntèë doem peukara

701 toedjōh ngòn djih nam dròë dilèë — djiseutèt asèë djeuët lapan ka roepa djròh that wareuna le ban - beusalahan doem oelama ladoem geukheun idjō koenèng - meudjampoe ladoem mirah wareuna

705 wareuna idja soephi ladoem riwajat - wareuna langèt ladoem kheun roepa nan pi le that han sòë toekri — sòjdina 'ali njang bōh nama

717 nan diarah toeanteu 'ali — di dara'in nan teuntèë njan kéntara moedjahada - di kōrasa njan neubōh nama

713 ébeunoe 'abaih kéteumi nan — soe'ib hameuran neubōh nama 
728 'abeudōlah nan salam sabeuti beurasi - di wahabi takeuta nama

734 di abi sapiah njan katimoen - hana sapeuë kheun doem oelama

737 nama le that roepa le ban - malingkan toehan thèe sibeuna

740 kata moehamat ébeunoe moeti - dakaleusi sabét koenèng wareuna

742 ahalōjtapeusé le that kilaï - teutapi alah thèè sampōna

744 kéteumi seutèt njan di likōt - teuma djidhōt poera-poera

747 kéteumi bè ${ }^{s}$ taba sadjan — djeuët keudjian geutanjòë doemna gèt tatinggaj bès taba lé - doem djisaré meunan kata

752 kéteumi leungò meunan narit - ma djilipat gaki doea djab ngòn dada oebas ${ }^{s}$ boemòë - seureuta djimòë ilé ië mata seureuta djiseuboet ngòn kalimah - bès takeubah oelōn taba

755 atjeuhadoes an la élaha élalah - moetjab kalimah ngòn sō $^{s}$ sama

758 lōn és $\mathrm{sa}^{s}$ si pòkoe toehan - hana la ${ }^{s}$ én sibagòënja oelōn teungkoe bè ${ }^{s}$ tatinggaj - oelōn kawaj teungkoe doemna

764 ban djileungò narit moemeunan — djiba sadjan han lé da ${ }^{5}$ wa

765 djiteungòh glé trōih ba ${ }^{s}$ pantòn - teuma djikalòn sabòh goeha

768 djabaj koeloeih njan djimeunan - wasiah toean nama goeha goeha indah hana padan - kroeëng didalam ië moemata

772 padoem-padoem ngòn makanan - timòh disinan djabét keureuma

774 masa $^{\text {s }}$ di ba ${ }^{5}$ srōt ba ${ }^{s}$ roengkhé - djipadjōh lé sama-sama

778 kéteumi kawaj djiśéh di pintō - oereuëng laloe doem djisangga oeròë malam teungeut dji tan - baranggadjan lam meudjaga

782 oeba $^{5}$ malingkan mawòt peureuman toehan — dja ${ }^{5}$ lèh katrōn oelam đōnja katoeëng njawòng oereuëng toedjōh dròë — kadja ${ }^{5}$ djinòe njan beusigra

778 oemoe habéh doemdji sampòë - ban toedjōh dròë siseun pahna tinggaj kéteumi kawaj pintō - printaïh pò toehan asa

792 ban toedjōh dròë siseun reubah - peureuman alah neujoeẻ plara

794 doea dròë malas ${ }^{s}$ kat bas ${ }^{s}$ sidròë manjèt - meunan sabẻt djịplara

795 djibalés wië njan ngòn oeneun — tréb-tréb siseun meunan keureudja sithōn siseun njan djibalés - nameung bè $\mathrm{e}^{s}$ brō ${ }^{s}$ toebōh meulia

798 'òh trōïh oeba ${ }^{s}$ boeleuën mèhram - moebalés siseun manjèt lam goeha

801 soerōh toehan bas mata oeròë - neujoeë saweuë bès binasa na thō toebōh bè ${ }^{s}$ brōs djasat - soerōh halarat keupadanja djis'és oeròë keunòng badan - pihas oeneun keunòng tjahja 'òh lōb oeròë blah wië keunòng - ateuëh goenòng dalam goeha

805 aseuhabōjkapi sinan teutab - moewòë riwajat oeba ${ }^{s}$ radja

807 sadjan djiteubiët njan oe mideuën - dji 'eu koenangan hana teuka aneu $^{5}$ nam dròë hò ka leupaïh - tjoeba peugah hò djiboengka teuma seuneus ōt tandi boedjang - leupaïh djiploeëng hé sròëpada

813 djidja $^{s}$ mita la ${ }^{\text {sén }}$ toehan - keu djoendjōngan han djipeutjaja 
826 lheuëh njan radja djikrah $\mathrm{ra}^{s}$ jat - timoe barat djijoeë mita

856 lapanplōhribèë kandran parisi - geuseutèt ladjoe $\mathrm{dja}^{\mathrm{s}}$ moemita euntjit beukaih tapas $\mathrm{ra}^{\text {s jat }}$ - moebalas gidoeës goeda hingga trōih $\mathrm{ba}^{s}$ sabòh goenòng - teuma meuteumeung sabòh goeha

869 ma djitamòng lé oedalam - ban djikalòn teungeut njidra

... teuma djimarit sabé keudròë-dròë — bès tapoewòë teumeureuka

... meuhat djisés sa lé kianòih — radja paléh tan agama

... gètkeu takheun hana meuteumeung - djiwòë reudjang ra ${ }^{s}$ jat doemna

896 'òh saré trōih ba ${ }^{s}$ kianòih - ma djikheun deuïh sigra-sigra

898 ampōn toeankoe hankeu na lé — salèh ka maté dalam rimba djeuëb-djeuëb seuroekan ka meutamòng - hana meuteumeung meudjas mita

901 oedéb ngòn maté hana meutoe‘òh — radja kianòih han lé haba padoem lawét hana meuteu ${ }^{5}$ ò - kakeu gadòh han lé geumita hingga maté radja las nat - oedéb lé jōhnjan oereuëng lam goeha

906 lhèëreutōih thōn ngòn sikoereuëng - hantòm oereuëng keunan teuka 917 toehan peus soedéb njawòng ngòn toebōh — siseun ban toedjōh sadjan djaga

921 ban djikalòn mata oeròë - marit sidròë njang peutoea

925 dami alah geutanjòe rakan - toewò keu toehan teungeut njidra simalam soentōos ta ${ }^{s}$ éh seunang - keu seumajang han takira teuma djibeudòìh doem dji saré — dja ${ }^{s}$ mita ajé han sapat na kroeëng habéh thō kajèë maté - ōndji han lé ba ${ }^{5}$ tangkénja tjabeuëngdji ka brōs ba $^{s}$ treus tinggaj - hireuën akaj gadòh bitjara

930 simalam $\operatorname{ta}^{5}$ éh teungeut pansan — kajèë doem tan misé njang ka $\mathrm{ba}^{s}$ pi ka brōs tjabeuëngdji han lé - gadòh piké geutanjòë doemna proeëtteu pi deuës lagi ngòn grah — pakri ilah hé tjèëdara geutanjòë deuës makanan tan $-b^{s}$ sòë rakan na blandja hana sabòh na sòë seu'ōt - teuma marit njan tamlékha

935 hana sidròë bri makanan - malingkan laman njang na blandja tabri dalém keu lōn peukajan - lōn dja ${ }^{5}$ oe peukan djinòë sigra hana adòë peukajan di kamòë — ngòn alat dròe tadja ${ }^{5}$ gata tamlékha $\mathrm{dja}^{s}$ teuma sidròë - $\mathrm{dji}^{\mathrm{s}}$ eu nanggròè han ban njang ka

940 rèt han meuhò peukan han moepat - kakeu sisat moeda balia

942 'òh saré trōih rab ngòn mideuën — leumah djikalòn sabòh roepa

944 meusoerat kalimah ateuëh pintō - meudjampoe lé ngòn nama 'isa

945 la élaha élalah 'isa rcehōlah - neukheun pantaïh sigra-sigra teuma neukoetjoeëb moeda samlakòë - ngòn doea djaròë oebas ${ }^{5}$ koepala

951 teuma neutanjòng oeba ${ }^{s}$ rakan - kamana djalan tatrōn oe banda hò salèh rèt tadja ${ }^{s}$ oe peukan - kamòë sadjan teungkoe taba 956 'òh sadjan trōih njan oe peukan - tanjòng ba ${ }^{s}$ rakan doem peukara 
958 peuẻ nan mideuën teungkoe tapeugah — sòë khalipah peuë nan radja

960 abeudōrahman radja kamòè — akeusoeih geuhej nama banda

962 kheun tamlékha oeba ${ }^{s}$ sahbat - njan 'adjab that oebas hamba njòë na deureuham wahé rakan - tabri makanan peuë halé na ban djikalòn ngòn deureuham — 'adjab han ban gadò bitjara

965 deureuham rajeu ${ }^{s}$ siplōh maih brat - tahekeu $\mathrm{ra}^{s}$ jat ban sineuna

... djiseu teusoerat bas deureuham — rakam toean nama radja

... radja kianòih djis eu teusoerat - hireuënkeu ra ${ }^{s}$ jat ban sineuna

966 habaran tanjòng bas moeda samlakòë - pat hé adòë tateumeung peudeuna di lōn ladoem adoë meutoeah — meung han lōn peugah oebas radja tamlékha seu ${ }^{s}$ òt neumeusoempah — walah bélah kòn peudeuna sibas ${ }^{s} a^{s}$ kajèë oelōn poeblöë - na thèë oeròë bas keukira

970 oelōn boengka di madinah — han lōn seumah radja tjilaka di kianòih radja kamòë — na lhèë oeròë tjré ngòn radja habaran leungò tamlékha peugah — boekòn brakah narit peuboela hana patōt takheun moemeunan - keureuna radja njan tréb ka pahna lhèëreutōihsikoereuëng thōn radja ka maté - han moepat lé roemòh tangga

975 padoem-padoem radja ka meugantòë — 'adjab kamòë haba gata meuseuhoe that trōih oe dalam - meugah toean trōïh bas radja keuleungòran oebas soelōtan — meugah oereuëng trōn di rimba 978 teuma geuba njan oe dalam — ras jat pi sadjan moeplōh la ssa 980 sabda radja oeba ${ }^{s}$ boedjang — panè oereuëng njan keunòë teuka

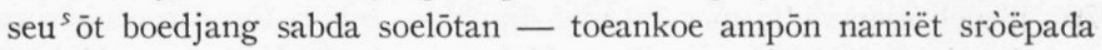

987 patōt toeankoe tatrimòng boeloeëng — bagi limòng misé njang ka sabòh bagi milés djoendjōngan — njang ka meunan hoekōm sròëpada njan di djihnjan han djitém peugah — patōtkeu salah teumeureuka

992 ampōn toeankoe djaròë gaki - han peuë lōn bri hana peudeuna

993 hana toeankoe peubandaharan — njang na deureuham njòë na doea

995 laman toeankoe lōn poeblòë kajèë - masa dilèë lōn ploeëng ba ${ }^{s}$ radja

1005 moewèh moebòih nanggròë - na lhèë oeròë tjré ngòn radja

1007 mideuën akeusoeih toeankoe di kamòë - lam nanggròë njòë roemòh tangga

1012 ampōn toeankoe laman lōn keunaj - meung na tinggaj roemòh hamba

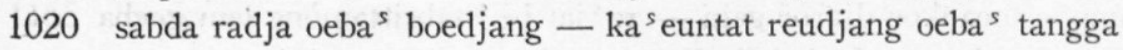
1022 'òh saré trōïh njan oe gampōng -- tamòng djoerōng trōïh oe tangga 1023 'òh saré trōïh njan oe roemòh - teuma djis oeròh njang ampoenja 1024 oereuëng di loea njang meussoeròh - sòë di roemòh pintō taboeka ... tawèh reudjang gata sinan — djikheun meunan doemdji rata 
1025 ban djileungò narit moemeunan - djiteubiët jōhnjan oereuëng toeha oemoe djameun sangat leutéh $-\bar{o}^{s} \mathrm{dji}$ poetéh di koepala boengkōs $^{s}$ ngòn roeëng krōt ngòn babah - keunèng poetéh teutōb mata oereuëng toeha sit that lawét - keunèng ka srōt ateuëh mata hantòm leumah neukalòn langèt - meunan sabét bas tjalitra

1031 sòë di pintō meuhej kamòë — sòë nan geuhej panè gata

1032 djiseu ${ }^{s}$ tkeu ra $^{s}$ jat tanjòng toean siah njòë - kamòë toean soerōh radja 1033 neujoeë euntat oereuëng moeda njòë — ba ${ }^{s}$ roemòh njòë djikheun areuta 1035 djikheun didjih njòë roemòh njòë — patōtkeu djinòë tawèh gata

1037 siah leungò narit moemeunan — mirah padam ngòn ië moeka siah tanjòng ngòn amarah - tjoeba peugah söë nan gata

1039 meungka meunè meungka meusòë - patōt moebòih dròë han meuda wa 1044 na taleungò toean siah — kamòë peugah nan tamlékha

1045 ébeunoe kitin nama ajah — kamòë tréb ka leupaïh dalam goeha

1056 toean siah ingat oereuëng njang gadòh - masa meuteu sòh ngòn nabi 'isa 1058 lajeuë keuradjeuën radja kianòï — nam dròë gadòh koenangan radja oereuëng geumoebeuë kamèng sadjan sidròë — meunan sabòh ròë haba isa 1060 asèë sabòh ngòn njan lapan - doem sikeulian tamòng lam goeha meunan teusingat dalam até — siah soedjoet lé bas tamlékha seumah di gaki tjöm di djaròë — koetjhis kamòë njöë di gata tjèëdara koetjhis kheun njan gadòh - masa meuteus'òh lōn ngòn 'isa

1064 tahekeu $\mathrm{ra}^{s}$ jat ban di nanggròë - trōih moeboenjòë oeba ${ }^{s}$ radja 1067 radja teuma pi neubrangkat - neupeu'èdat moeda balia

1069 'òh saré trōïh bas moeda samlakòë — neutrōn lé djinòë ateuëh goeda 1070 lheuëh njan radja moemat-mat djaròë - teuma meuntròë ngòn panglima doedòë teuma imeum ngòn $\mathrm{ra}^{s}$ jat - geubri 'èdat keu tamlékha lheuëh moemat-mat djaròë doeës meuhimpōn — djaròë djiseusoon ateuëh djeumala radja tanjòng bas moeda samlakòë — rakan nam dròë hò salèh ka 1075 rakan nam dròë hana keunòë - sidéh djinòë dalam goeha 1076 sabda radja bas moeda samlakòë - oedéhta djinòë dalam goeha oelōn $\mathrm{dja}^{s}$ kalòn peuroesahan — doem sikeulian asòë goeha

1090 radja brangkat ngòn piasan - djiseutèt sadjan sabòh treus radja 1093 radja nasrani pi brangkat - padoem ngòn $\mathrm{ra}^{s}$ jat balatantra 1096 'òh saré trōih ra ${ }^{s}$ jat keunan — tamlékha jōhnjan kheun bas radja ampōn toeankoe djaròë gaki — ra $^{s}$ jat bès tabri tamòng lam goeha oereuëng lam goeha habéh djoeah - keureuna soesah keu pò meukoeta beukit han djiwèh salèh djilawan — djisangka rakan radja tjilaka

1100 djisangka ka tröïh radja kianòih — djikeundas ${ }^{\text {s }}$ pòh pò meukoeta 1103 njòkeumeunan moeda samlakòë — bahlé doedòë lōn ngòn gata 
radja nasrani teuma sidròe - thèè ngòn kamòe tamòng lam goeha

1105 "ò neutamòng radja leupainh — aleuhamdoelélah lé neubatja

1107 aleuhamdoelélah alladi nadjakōm mèn dakianöïh - doe'a njang

ma ${ }^{8}$ roeih niba ${ }^{8}$ radja

1108 radja tanjòng bas oereuëng njan - padoem na djameun sinòe gata

1109 jauman au ba ${ }^{5}$ la jaumèn - meunan djikheun doemdj̣i rata

1111 beukeuhan si soeròë sikhan oeròë — kamöe keunòe ka lam goeha seu'ōt radja kònkeu doemnan - lhèëreutōih thōn sinòe gata sikoereuèng thōn lòm meutamah — dalam salasilah meunan njata

1115 radja kianòïh tréb ka maté - metugantòë lagi padoem radja

1118 radja tanjòng bas moeda samlakòë - pakri djinòë moeda balia peuë na hadjat dibas kamòë - takheun djinòë meungò njata na takheundas djas kalòn nanggròë — takheun djinòë sigra-sigra

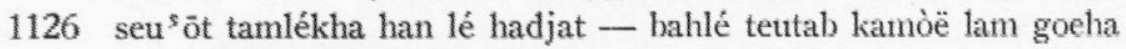

1126 hanlé hadjat njan keu nanggròë - bahlé sinòë pò meukoeta lheuëh njan tamlékha doe'a neubeuët - seureuta neubeu's ${ }^{\mathrm{s}}$ euët djaròë doea alahōma bihaki ajatina minan 'adjas ${ }^{5}$ ibi pi ampoesina éla képeuta aroeahana walam jōteulas 'alòëna ahakōn - meunan neukheun neubeuët doéa

1132 ja toehankoe deungòn sah sibeuna — barang njang lahé niba ${ }^{5}$ hamba kakeu leumah njang 'adjajéb - oelōn bès tréb tatoeëng njawa bès leumah lé oeròë njang lasén — sébkeu ngòn njan ja rabana

1135 kalam pi habéh njawòng gadòh — siseun ban toedjōh sigò pahna goeha teutōb radja teubiët - teuma geukeumiët doem di loea toedjōh oeròë radja di sinan - doem sikeulian ra $^{\text {s }}$ jat doemna

1147 radja moepakat deungòn $\mathrm{ra}^{\mathrm{s}}$ jat — pakri mangat geutanjòë doemna

1149 gòb njan maté agama geutanjòë — patōt djinòë tabōh tanda

1150 patōt takeubah sabòh meuseudjit - teumpat diarah sòë njang teuka

1153 radja nasrani djikheun bès meunan - maté gòb njan agama hamba

1155 patōt tapeugèt sabòh koebah - teumpat takeubah patōng beurala

1157 doea radja han moepakat - meukōseumat di babah goeha doea radja ka moepeugang - hingga djeuët prang meuseunòh goeha

1160 keureuna goeha njan bas tjeuë nanggròë — ban doea dròë djikheun milés nja

haba poeprang han lé kisah - mit keureutaïh da ${ }^{s}$ weuët hana 'òh geukheun prang pi ka mas loem - beudé tamtoem hana reuda

1165 'òh ka djeuët prang patōt pantaïh - talō siblah kòn ban doea meunang éseulam talō kaphé - hana sòë lé ngòn meuda ${ }^{s}$ wa geupeugèt meuseudjit han lé koebah — peureuman alah lahé njata lanattakhidanna 'alòëhém maseudjida

1182 meunan neukisah sòjdina 'ali — tanjòng jahoedi asaj moela 
1184 'ali tanjòng teuma doedòë — njò bit meunòë lam tèërit gata

1185 seu $^{s}$ ot jahoedi sabét beuna - han meutoeka hé sòjdina

... hé aboe hasan taleungò kamòë — bè̀s nan lōn lé misé njang ka

1186 djinòë meutamòng agama nabi — han lé jahoedi di kamòë nama atjeuhadoe $^{s}$ an la élaha élalah wa atjeuhadoe ${ }^{s}$ anna moehamadan rasoelōlah — 'òh nòë kisah ka sampōna aseuhabōjkapi kisah le that - maséng riwajat doem oelama

1190 le that khileuëh hana saban — maséng jakin keu rabana tamat al kalam pada hari sabtoe — akhé leuhō awaj 'asa wasalalahoe 'ala sòjdina moehamadén wa'alihi wasahbihi wasalém

\section{AANTEEKENINGEN.}

$2 \mathrm{AB}$ : Ébeunoe 'Abaih is Ibn 'Abbās, vermeld door Huber op p. 18 etc.

22 B : Het vers vertoonde een gaping, die in de Latijnsche transcriptie werd gedicht door invoeging van „han lé djimòë”. Die wijziging is hier overgenomen.

$45 \mathrm{AB}$ : Over Omi Sébeujan (in Idi meen ik Oemi Sabian verstaan te hebben), de kinderduivelin, die in Arabië waar zij thuishoort, oemm aç-çibjān d.i. ,moeder der kinderen” heet, zie Snouck Hurgronje's „Mekka” II pp. 123-124 en Dr Hoesein Djajadiningrat's Atjèhsch-Nederlandsch Woordenboek.

62 B: De eerste vier voeten mankeerden. In de lat. transcr. werd het vers gecompleteerd met „oelōn soerat lōn peuteuntèë, als hier overgenomen.

70 AB: Koerān 18:8 zegt: „Of meent ge soms, dat de lieden van de grot en van de rakim een verwonderlijk iets waren onder de teekenen?!" Bedoeling: dàt was nog maar een kleinigheid! we hebben wel grooter wonderen gewrocht! (Mededeeling wijlen prof. Snouck Hurgronje).

Het Arabisch is in B weergegeven naar de lat. transcr., welke er een is van Atjèhsche hand.

$71 \mathrm{AB}$ : Tha'labī noemt als zegsman van het verhaal der drie hollemannen, An-Na'mān, die zijn wetenschap zeide ontvangen te hebben van den Godsgezant. Is die An-Na'mān door slechte lezers of copiisten vervormd tot den 'Ojnòn na "im (,Oog van den lieflijke”) in Atjèhsche teksten? 
$150 \mathrm{~A}$ : hakoe taala $=$ den Reëele, den Verhevene.

210 B: „Rakim” wordt hier gezegd volgens Ébeunoe "Abaih „wadi” dus een soort dal te beteekenen. Dat laat ook Tha'labi Ibn 'Abbās zeggen.

Van $K a{ }^{\prime} b$ en diens verklaring van Rakim als naam van de stad der hollemannen, door Thalabi vermeld, wordt gezwegen.

Sa'îd bin Gabīr, die volgens Tha'labī „rakim” vertolkt met lei of looden tafel, waarop de historie der hollemannen zou zijn gegrift geweest, heet in B: Sa ${ }^{5}$ at ébeunoe Dabé, wien gelijke verklaring wordt toegeschreven.

215 AB: Dat de geschiedenis zich afspeelt in het tijdvak tusschen Jezus en Moehammad, zegt ook 'Tha'labì.

240 B: Vert: „Als ik 't niet weet te zeggen, staat dat niet!' Zijn wetenschap ging niet zoo ver. Hij zei : „Neen!”

In de lat. transcr. is ",bas han" veranderd in ,meukheun". Daarmee is wel een schildering verkregen, hoe Oemar stond te schutteren, maar de afwijking is te grooter geworden van een vermoed voorbeeld, dat Tha'labi's tekst nader stond, waarin Oemar zegt: ,'t Is geen oneer voor Oemar, zoo hij, naar iets gevraagd wat hij niet weet, antwoordt: ik weet 't niet! en als hij naar iets vraagt wat hij niet weet!"

242 B: Atjèhsch Arabisch, overgenomen uit lat. transcr.

247 AB: Salmān Fārisī (Soelòjman Parisi), een Pers uit Moehammad's dagen, een van de groote heiligen der Sjiieten.

242 B: Vert. :Ik getuig dat Moehammad géén profeet is, noch de godsdienst van den Islām de ware.

274 AB: Arab.: moesjrik billāh $=$,met Allah zijnde” of, in slechten zin: „die Allah genooten toekent” dus: polytheist.

$284 \mathrm{AB}$ : Als inwoner van het mobiele graf noemt A per abuis „,nabi Nòh” d.i. Noach! In B is 't Joenòih d.i. Jonas. De visch Noen, die hem logeerde, heet in B: Hoet, wat ook het teeken is van den visch in den Dierenriem.

292 AB: Als wezen, niet uit een moeder geboren, had in plaats van Salomo's mier, de stok (slang) van Mozes moeten zijn genoemd, als in tekst Tha'labì.

296 AB : Salèh, een profeet, uit het Oude Testament niet te verklaren, evenmin als Édeurih (Idris, Andreas?) en Hoet (Jahoed, Juda?).

A geeft ,nabi Salèh” voor „oenta nabi Salèh, een fout die werd hersteld.

312-322 - 331 B : Atjèhsch Arabisch, overgenomen uit lat. transcr.

$319 \mathrm{AB}$ : Het hinnikende paard is bij Tha'labi een balkende ezel.

Deel 98. 
342 -346 AB : Bij Tha'labī geven, na de oplossing hunner raadsels, twee van de drie Joden zich gewonnen; zij omhelzen den Islām. Maar de derde heeft nog één vraag: hij wenscht te hooren van de lieden, die uit 309-jarigen doodslaap door God weer in het leven werden teruggeroepen. Ali's wetenschap wil hij toetsen aan wat hemzelf uit de Thora terzake bekend is.

De Atjèhsche teksten daarentegen laten àlle Joden zich bekeeren nadat hun raadsels zijn opgelost; daarna wordt geïnformeerd naar de herleefde dooden. Dat die lezing niet deugt, blijkt aan het slot, waar de vrager nog als Jood wordt aangeduid, en hij na geconstateerde overeenstemming van Ali's lezing met eigen wetenschap uit de Thora, de geloofsbelijdenis (wij merken op: ten twééden male) uitspreekt.

Bij Tha'labì wordt Ali onder het vertellen telkens in de rede gevallen door zijn Joodsch gehoor, dat opspringt om bijzonderheden te vragen, die dan feilloos door Ali worden gegeven. Daardoor wordt men er telkens aan herinnerd, dat Ali aan het woord is. In de Atjèhsche teksten merkt men niet van interrupties, en Ali wordt als verteller alleen aan het begin en aan het eind genoemd.

369: Bij Tha'labī is Ephesus de oude naam uit de dagen van vóór den Islām, van Tarsus.

In de Atjèhsche teksten is Ephesus geworden tot Akeusoïh. Een nadere plaatsbepaling Bariah (= woestijn) inA, luidt in B Keuriah (= globe, sfeer).

393 A : Dat de oude sjeich een overlevende uit de dagen van Mozes heet, komt kennelijk door de nabuurschap in den tekst van oude documenten uit Mozes' dagen.

$425 \mathrm{~B}$ : Er stond: Gèt koedjas ${ }^{s}$ pòh iblih njan dilèë. Ik wijzigde dat in siah.

525/9 AB: Pra'ōn of Pra'oen, Ar. Fir'aun, is Pharao. Zie Sn. H.'s „De Atjèhers” II 172 en Dr Hoesein's Atj.-Ned. Woordenboek.

Karōn is Korach uit Exodus en Numeri.

Nameuroet de bijbelsche Nimrod, de groote jager.

'At de gepersonificeerde rebel.

540: Bij Tha'labī schrikt de koning op het bericht dat het Perzische leger tegen hem oprukt. De kroon valt hem van 't hoofd en zelf glijdt hij van zijn troon. Tamlicha ziet dat en trekt conclusies, die door zijn makkers worden gedeeld: Daqjanus is géén god, maar een kleine menschelijke tiran; dus willen zij hem verlaten, om zich te wenden tot den koning van hemel en aarde.

Rudimenten van die lezing vindt men in teksten A en B, waar 
in A de waarschuwende mantri den vorst vertelt, hoe de jongelieden hem, den Perzenvorst, willen dooden; terwijl ze hem in B hebben gescholden ,,soldaat van den Perzenkoning”. Die dreiging tegen zijn leven brengt Kianos van zijn stuk, en maakt, dat hij zich aan Tamlicha nog eens ten overvloede doet kennen in zijn kleine menschelijkheid.

$586 \mathrm{~B}$ : sa sé, Ar. sasir $=$ de rest, al 't overige.

De lat. transcr. geeft sabé.

609 B: mankeert in lat. transcr.

635/6 B: In lat. transcr. gedeeltelijk weggevallen.

639: Bij Tha'labī 3 drachmen, in A 3 Perzische drachmen, in B 3 drachmen van Ephesus.

652: A laat het zestal 7 parasangen te voet afleggen, conform Tha'labì; in $B$ is 't 70 , wat veel lijkt!

$708 \mathrm{~A}$ : hisabi terwille van het rijm, voor hisab. „Zoo zegt men in de rekening" staat er.

713/743 AB: Over naam en kleur van den hond, en zegsmannen daaromtrent; dus veel verhaspelde namen, die bij vergelijking met opgaven van Tha'labì e.a., voor een deel wel zijn thuis te brengen.

De verzen loopen niet steeds rond, het rijm mankeert soms. Lat. transcr. B heeft herstel beproefd met onbevredigenden uitslag.

Manjèt in A en Moeti in B, en Teulheuëh in A en Kaleusi in B zijn verschillende lezingen van oorspronkelijke gelijke Arabische letterbeelden.

768: De berg heet bij Tha'labī Nädjlūs, in A en B Djabaj Koeloeïh; de grot bij Tha'labī Al-wașìd, in A Ramét, in B Wasét of Wasiah.

856/900: Tha'labī laat de opsporing der 6 uitgewekenen door 80000 ruiters geschieden, onder persoonlijke leiding van den vorst. Nadat hij hen slapende heeft aangetroffen, laat hij, tot hun straf, de grot dichtmetselen. A en B missen vorstelijke aanvoering en toemetselen. Tekst A vertoont veel borduursel.

794: in A twintig, in B twee engelen de persoon. Tha'labī zegt: twee engelen.

914 A: Over Radja Djōmdjōmah zie Sn. H.’s „,De Atjèhers” II 173 en 188: „Koning Schedel, wiens schedel met Jezus sprak en die door dien profeet tot een nieuw en godzalig leven werd opgewekt".

936: Tamlicha's verzoek om kleeren te mogen leenen, toen hij de grot zou gaan verlaten om te fourageeren, was blijkens Tha labī gericht tot no. 7 van het gezelschap: den herder. Hijzelf 
en zijn vijf makkers waren als hovelingen natuurlijk te mooi aangedaan, om incognito de markt op te gaan.

In $\mathrm{B}$ is die passage niet begrepen en krijgt Tamlicha een afwijzende beschikking op zijn verzoek, met aanbeveling om zich maar in zijn eigen plunje te steken.

945 B: Nagenoeg conform lat. transcr. Alleen anladi gewijzigd in alladi en dinen Kianöih in Dakianöih.

966: Bij Tha'labī vertoont de munt den beeldenaar van Dakianos.

1104 B: De vorsten gaan met Tamlicha mee naar binnen en spreken met de ontwaakte slapers. Dat is anders dan bij Tha'labī, die alleen Tamlicha naar binnen laat gaan en vragen stellen aan zijn makkers; de vorsten wandelen bij hem 7 dagen lang om de grot heen, zonder dat zij er in slagen daar binnen te komen.

1107: „Lof zij Allah, die U gered heeft van Kianos!” Bij Tha'labi is dit de begroeting die Tamlicha bij terugkomst gewordt van de zijde zijner makkers.

1107 - 1109-1128-1163-1187 B: Atjèhsch Arabisch van Atjèhsche hand, uit de lat. transcr.

1131: Het Arabische citaat is uit Kisas 247 : „Wij bezweren U o God, bij de waarheid van hetgeen Gij ons hebt doen zien aan wonderlijke dingen in onze zielen, - hebt Gij dan niet onze zielen genomen? En er was niemand die van ons wist!"

1168 A : Koerān 18 : 20: „Wij zullen zekerlijk voor hem een moskee bouwen".

1195 A: Boedoeh, geen woord, maar een samenstel van 4 letters: ba-dal-waw-ha met cijferwaarden 2-4-6-8. Schuin in den rechter bovenhoek van het adres geschreven, verzekeren zij het terechtkomen van een brief. De werking is dus als van den hondennaam Kitmir of Katmir, en naast elkaar geplaatst zullen ze elkaars werking mogelijk verhoogen.

1195: De Arabische karakters waarmee de Zeven Heiligen worden aangeduid, laten nog al verschillende uitspraak hunner namen toe.

De Atjèhsche scribent, die tekst B in Latijnsche karakters afschreef, transcribeerde:

Tamlika, Tamlikha

Makeusajmina, Makasalémna

Mareuțoeanòï, Mareutoeanisoe

Noenoenòïh

Sireuboenòih, Saraboenisoe

Paleujaseutatioenisoe

Doe Noeanòìh 
In Idi hoorde ik uit tekst A oplezen:

Tamlékha

Makeusalémina, Mòksalémina

Mareuțoenih, Mareuțoeboenih

Noenoenih, Najnoenih

Sareuboenih

Paliaseutatioenih, Paliatatioenisoe

Dawōnoeanisoe, Doenoeanisoe

In een boekje $10 \times 16 \mathrm{~cm}$, toebehoord hebbend aan een kōmpeunis s vijand Teukoe Bén Arōn, en inhoudend twee gedichten van godsdienstige strekking: Sipheuët doeaplōh en Masasilaj, staat op de binnenzijde van het schutblad, een figuur: een combinatie naar het voorkomt van een amulet en een ex-libris: een cirkel van $72 \mathrm{~mm}$ middellijn, waarbuiten aanroepingen tot Allah en de vier rechtvaardige chaliefen, en waarbinnen vlak onder het ,ja Allah" buiten, een ,,ja Moehammad"; waarop volgen de namen van de zeven heiligen en hun hond. Dan volgt, geflankeerd door een ring van Salomo (vijfster) met aanroepingen van Allah en Moehammad het ex-libris: „Hada has milik Si $\mathrm{Nja}^{s}$ Bén Arön”. De Zeven Heiligen van dit amulet zijn: Maksalimina, Masalina, Tamlicha, Marnoes, Dabarnoes, Sanoes, Marțoes.

Ook in Snouck Hurgonje's bundel transcripties van Atjèhsche schrifturen, welke opent met de „Hikajat Tamlikha” (tekst B), staat tusschen de daaropvolgende ,Diverse doesa's” op p. 31 bovenaan: de reeks namen der Zeven Slapers, genoemd als ,,adjeumat” (amulet). Wij lezen: „Inilah azimat: Maksalmina wa Tamlicha wa Martoenis wa Naboenis (of Banoenis) wa Sarinoes wa Doewirasoe wa Kafsțatoenis. Tamat.”.

Gerth van Wijk (hiervoren p. 409) noemt koning van Roem: Dakianoes, stad Afsoes, van de slapers enkel: Jamlika en Maksilimna, hond: Fatmir, berg: Jandjaloes in landstreek Oeliasin. De zeven ashaboe'l kahfi ontwaakten uit 309 jarigen slaap onder den vromen vorst Nidoesi, toen twee vrome gouverneurs: Arioes en Sitalioes, Afsoes bestuurden. Twee vromen uit Dakianoes' omgeving, die hun geloof verborgen hielden, stelden het verhaal der zeven vrienden op twee looden platen, die zij aan den ingang van de grot in een aan de wand gehangen kist plaatsten.

In de door Gerth van Wijk vermelde Tapĕl Adam las Gunning als namen van hoeloebalang's van Doekajanoes, vorst van Roem: Tamlika of Namlika, Nalika, Tantanoes, Oenoes, Maroenoes. De hond heette Patmir, en was eigenlijk de pandita Balaoem (Bileam uit Numeri 22). Een Tapĕl Adam uit de Leidsche Universiteitsbibliotheek (872 F 144) van 1903 
schijnt overeen te stemmen met de door Gerth van Wijk bedoelde.

Voor namen in diverse Arabische teksten zie Huber p. 94 e.v.

Orientatie inzake de Zeven-Slapers-legende geven vooral :

1. Enzyklopaedie des Islām, I, Aṣhāb al-kahf.

2. I Guidi : Seven Sleepers, in Encyclopaedia of Religion and Ethics, edited by James Hastings XI 1920.

3. P. Michael Huber O.S.B.: Die Wanderlegende von den Siebenschläfern. Leipzig 1910.

Litteratuuropgaven in 1 op p. 497 , in 3 pp. $214 / 221$. 